\title{
APPENDICULARIAN SPECIES GROUPS AND SOUTHERN BRAZIL WATER MASSES
}

(Received 13/8/1964)

\author{
Liliana Forneris \\ Instituto Oceanográfico da Universidade de São Paulo
}

\section{SYNOPSIS}

The distribution of 19 species of appendicularia sorted out of a series of plankton samples taken between Cabo Frio (lat. $23^{\circ} \mathrm{S}$ ) and Rio Grande do Sul (lat. $36^{\circ} \mathrm{S}$ ) is discussed in relation to temperature and salinity. Most species showed a wide spectrum of temperature and salinity tolerance. No species was found to be exclusive of a single water mass. Eleven species were present in coastal waters, 16 in shelf waters and 13 in tropical waters. Ten species were found in the three water masses. Oikopleura longicauda was the most abundant species and $O$. dioica was found only over the shelf.

Species of the genus Fritillaria were more sensitive to lower salinities and in a general way the number of species decreases coastalwards. Different groups of species were present in the same water mass and conversely similar groups occurred in different water masses. Five, eight and nineteen different groups of species occurred exclusively in shelf, coastal and tropical waters respectively. There was suggested the occurrence of stratified distribution and consequently the presence of different ecological niches within a single water mass.

Several species probably reproduce more than once, most species are proterandric. Parasites and predators are mentioned. It is suggested that the knowledge of the past history of the water mass and its biological dynamics are more important for the interpretation of the distribution of the appendicularian fauna than temperature and salinity factors alone.

\section{INTRODUCTION}

The knowledge of the plankton distribution may be useful in the interpretation of oceanographical data as well as in the study of water movements (Russell 1935, p. 6 and 13). This statement applies most closely to areas of pure water masses and to areas where conditions are more stable. Biological indicators of environmental conditions are difficult to assess in an area of oceanographical instability where mixing processes take place. It is also

This work was supported in part by a grant-in-aid from the National Research Council of Brazil awarded to the author during 1959.

Publ. n० 213 do Inst. Ocean. da USP. 
very ,difficult to explain if the differences between groups of species occurring within quite similar environments which are analysed only according to salinity and temperature parameters may be significant. The distribution of species and groups of species depends indirectly on the physical parameters but the composition and abundance of species is mainly determined by the history and biological dynamics of the water masses (Fager \& Mc Gowan 1963). The occurrence of a species or a group of species in a particular ecological space within a particular water mass is thus the result of a complex of factors. The different processes that occur at different seasons and as the water mass moves determine the patterns of distribution. A water mass in movement changes from one biological state to another, new elements may be added and others lost; this causes a continual reassortment of animals in the plankton community (Hardy \& Gunther 1935, p. 356) and the amount of the original fauna that persists may indicate the degree of the change involved (Fraser 1937, p. $313 \mathrm{ff} ; 1952$, p. $15 ; 1955$, p. 4). Also, the chemical environment changes since waters rich in nutrients become poorer and poorer when moving along an horizontal current, if enrichment does not occur (Steemann Nielsen 1954, p. 316). The age of the water is therefore of great importance (Sverdrup \& Allen 1939, p. 143). Biological factors and modifications of the surrounding environment cause continuous changes in the group of species involved (Beklemishev 1957, p. 209). Therefore, in order to interpret the emergence of a particular pattern of spatial distribution it is essential to consider the temporary state of the group studied and the actual conditions in which it is found. Of course chance may also be involved (Morrison Cassie 1960, p. 46). Tokioka (1960, p. 400) suggested that the composition of offshore appendicularian populations differs from time to time. The same is also true for coastal populations, which show variation in density and diversity.

The present studies were carried out in an attempt to explain differential composition of species of appendicularians in relation to environmental factors. The occurrence and abundance of species were related to the fluctuations in the temperature/salinity properties of the water masses but species are not necessarily limited by these factors alone (Mc Gowan 1960, p. 136). Where environmental conditions are optimal for a species it would then dominate but if several species found optimal conditions, each would be represented by a smaller percentage of the total population (Moore 1952, p. 297). Tolerance "of environmental change among species may be reflected by a wider or narrower distribution. Little information exists defining the position of the appendicularians in the plankton community. The distribution of different groups of organisms varies, especially in tropical regions depending on their place in the food chain (Vinogradov \& Voronina 1962). 


\section{MATERIAL AND METHODS}

The plankton here considered was collected during four cruises covering the area extending from about lat. $23^{\circ} \mathrm{S}$ (Cabo Frio) to about lat. $36^{\circ} \mathrm{S}$ (Rio Grande do Sul) and from long $41^{\circ} \mathrm{W}$ to about long $52^{\circ} \mathrm{W}$ (Maps 1 and 2).

The surveys covered a fifteen months' period but samples were taken only in September-October 1955, February-March, June and October-November 1956. A total of 136 stations were occupied but only the following sample series were analysed:

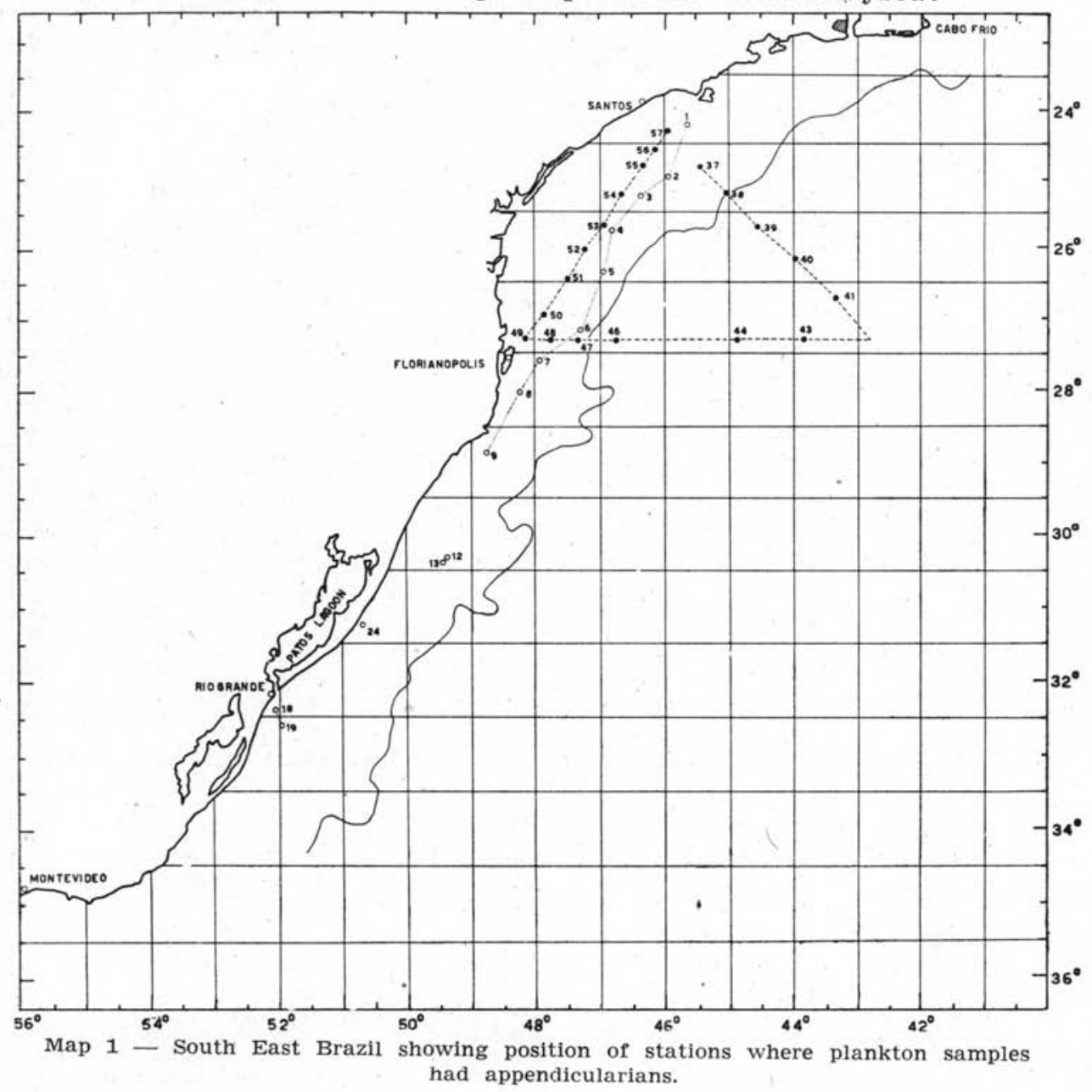

Cruise

"Presidente Vargas"

"Iguatemy"
Symbol

.......

$\ldots \bullet \ldots$
Numbers

$1-9,12,13,18,19,24$ 37-57
Date

September-October 1955

June 1956 


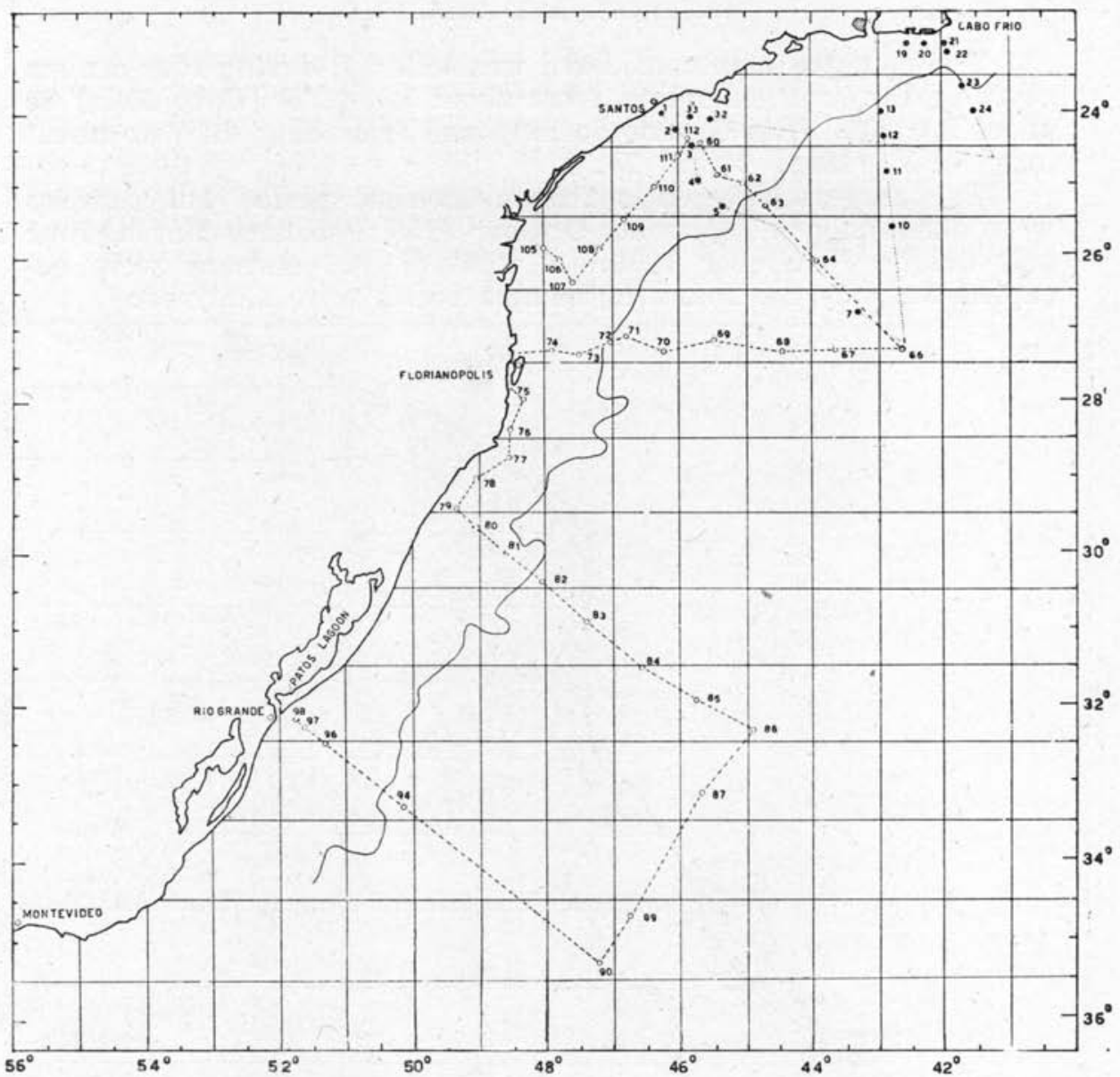

Map 2 - South East Brazil showing position of stations where plankton samples had appendicularians.

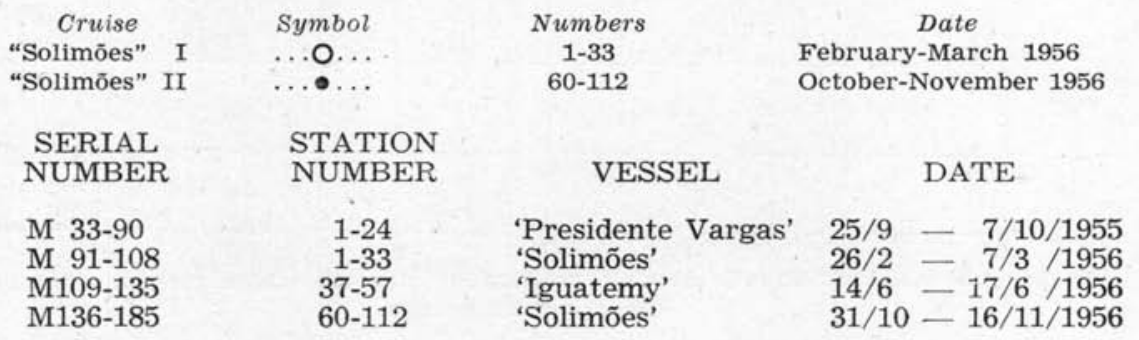

All data concerning stations where plankton samples contained appendicularians as well as numbers and percentages of each 
species were listed (Tables 1-4). Emilsson (1956) can be referred to for all the hydrographic data concerning 'Iguatemy' and "Solimões' cruises. Different nets were used: a "Standard" net (A) (Sverdrup et al. 1954, fig. 91), an Apstein egg net (B) and a Clarke-Bumps net (C). Plankton samples were obtained both horizontally $(\mathrm{H})$ and vertically $(\mathrm{V})$. The hauling time varied between 10 and 20 minutes. Sometimes the actual depths reached by the net could not be ascertained since only the metres of wire out (m.w.) were given and not the wire angle. The hydrographical data for the corresponding sample in that case were considered up to depth obtained dividing the metres of wire out by 3 . The various types of net hauls are not equivalent and for comparison each species of a sample has been considered according to the percentage it represents in the total appendicularian population of the corresponding sample. The number of specimens was determined by direct countings. No data on the volume of water filtered through the nets were available and it was impossible to determine the quantity of plankton per cubic metre. Therefore, only the horizontal distribution of the species, their frequency and grouping in different environments, the presence and occurrences related to temperature and salinity were studied.

\section{HYDROGRAPHY}

The layer studied includes the epipelagic zone (Hedgpeth 1957). Some samples of deep layers were obtained but scarcity of species and specimens was observed. Water masses of the upper strata were defined according to the characteristic combination of temperature and salinity.

The hydrography of the area has been studied by Emílsson $(1959 ; 1961)$. The region here considered represents a transition zone where mixing and instability with strong gradients especially of temperature and salinity occur. Pure tropical waters of salinity over $37.2 \%$ and temperature of $26.3^{\circ} \mathrm{C}$ (Okuda 1962, fig. 10) are not to be found in this area. Tropical waters referred to are a mixture of pure tropical waters from the north with waters of lower temperature and salinity. These waters mix again at the Sub-tropical Convergence and give rise to sub-tropical waters. Shelf waters are made up to mixed waters and are strongly influenced by subtropical waters. The salinity of coastal waters never exceeds $35 \%$ and temperature is usually higher than $19^{\circ} \mathrm{C}$. The coastal waters from Rio de Janeiro to the State of Paraná show salinities around $34.5 \%$. High salinity was recorded off the coast of the State of Santa Catarina due to the great influence of tropical waters (Emílsson 1961, p. 105). Although the area studied is situated in a zone of minimum plankton (Hentschel 1933, p. 10, fig. 2) a tongue of maximum values appears off Santa Catarina (Hent- 
schel \& Wattenberg 1930, fig. 3 and 4). Influence of fresh waters of Patos Lagoon and the La Plata River on the southernmost part of the coastal region is important. Horizontal movements of water near the coast are irregular and turbulence is great (Emílsson 1960, p. 5), a fact which certainly influences the distribution of the species. The general properties of the water masses that occur in the area surveyed are the following:

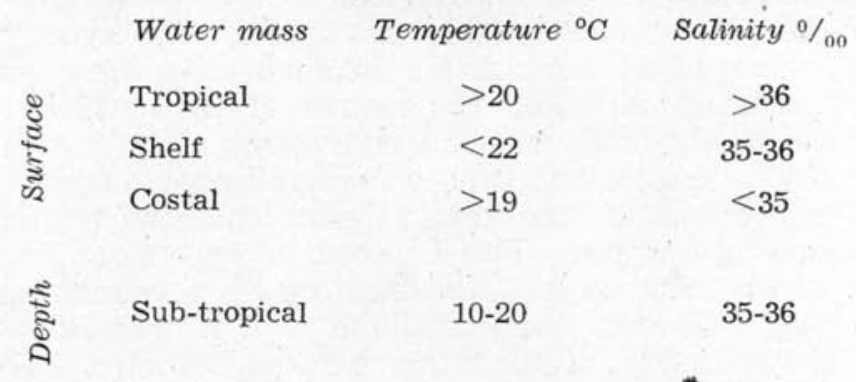

Waters with salinity greater than $36 \%$ and temperature around $18-19^{\circ} \mathrm{C}$ are considered as cooled tropical waters. Björnberg (1963, p. 7 and table IX, p. 108-9) called surface waters with temperature $18^{\circ} \mathrm{C}$ or less and salinity around $36 \%$ as surface sub-tropical waters. Yet, according to Emílsson (1959, p. 46) sub-tropical waters flow under the tropical ones. They can emerge at the surface modified as shelf waters. The limit of the Sub-tropical Convergence is difficult to settle, however in late spring it lies south of the area studied. Therefore, waters recorded in November between lat. $30^{\circ}$ and $35^{\circ} \mathrm{S}$ (Sta. 83, 84, 85, $86,87,89$ of 'Solimões') with salinity greater than $36 \%$ and temperature around $18-19^{\circ} \mathrm{C}$ certainly represent cooled tropical waters.

\section{NOTES ON THE DISTRIBUTION OF GENERA AND SPECIES}

a) Distribution of the genera (Fig. 1-2) - Data from the available literature show that the environmental preferences of different genera and of families of appendicularians is doubtful. According to Lohmann \& Hentschel (1939, p. 202) in a general way Oikopleura prefers warm waters and Fritillaria cold ones. Generally Oikopleura is more abundant than Fritillaria (Lohmann 1931, p. 29; Björnberg \& Forneris 1958, p. 82) but in a few cases Fritillaria is the most frequent genus (Björnberg \& Forneris 1956a, p. 106). Bernard (1958) and Fenaux (1959, p. 8) correlate the differential occurrence of oikopleurids and fritillarids to seasons. In the present material the genus Fritillaria was absent in some stations, but no correlation could be found between this fact and the environmental parameters analysed. The decreasing density 


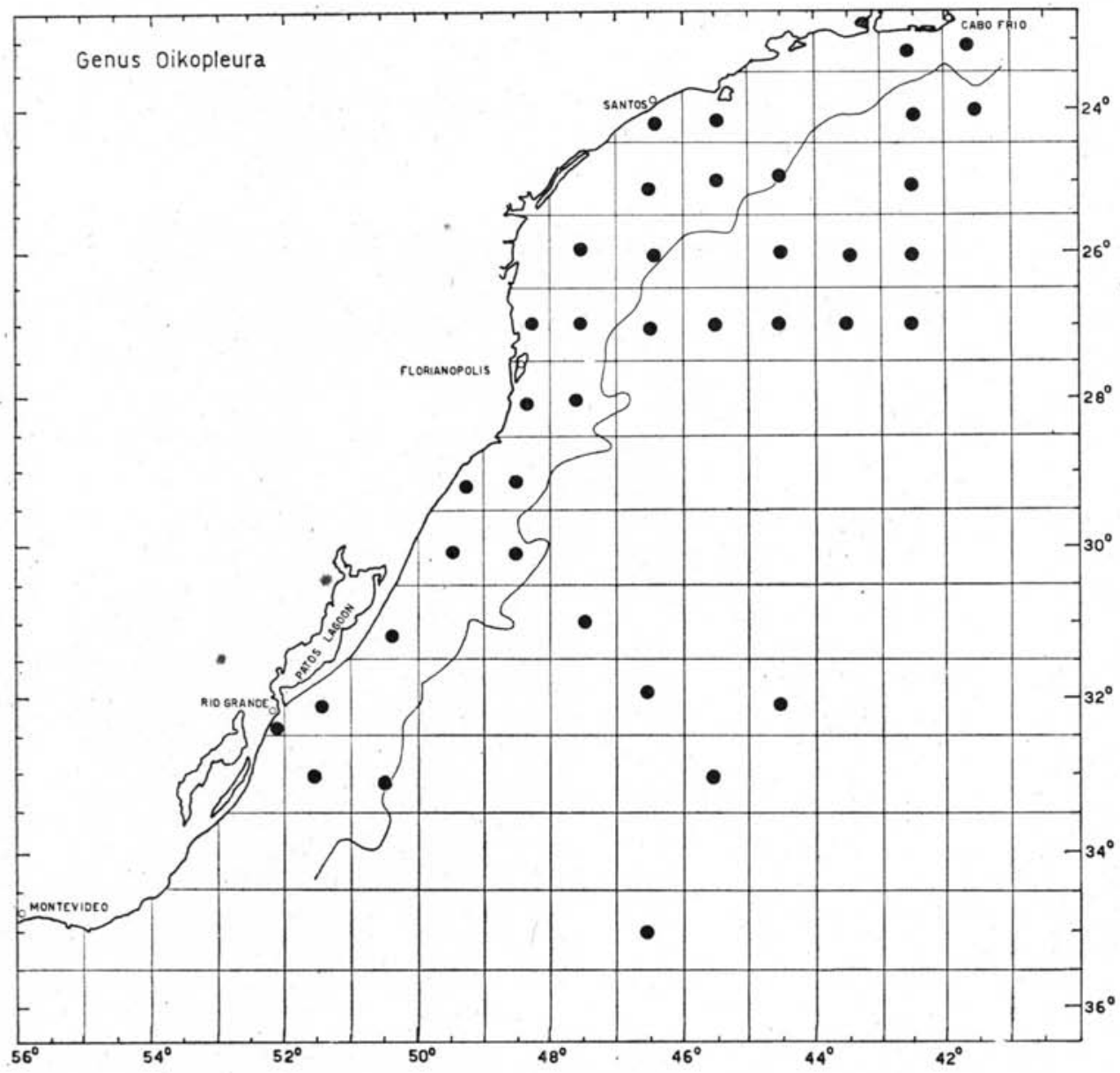

Fig. 1 - Distribution expressed as occurrence of genus Oikopleura in samples available for each 100 square. $200 \mathrm{~m}$ contour

of Fritillaria coastalwards may be due to its sensitivity to dilution. Oikopleura was only absent at Sta. 7 of 'Solimões' which was under the influence of tropical waters of high temperature and this single record may be interpreted as a coincidence. In general most of the stations showed higher numbers of Oikopleura than Fritillaria. The latter genus was more frequent in number of specimens in only a few stations in coastal, shelf or tropical waters. Fritillaria was more numerous than Oikopleura in not very diluted coastal waters $\left(34^{\circ} \%\right.$ ) with relatively low temperature $\left(18^{\circ} \mathrm{C}\right)$, in shelf waters of low temperature and in tropical waters of high tempera- 


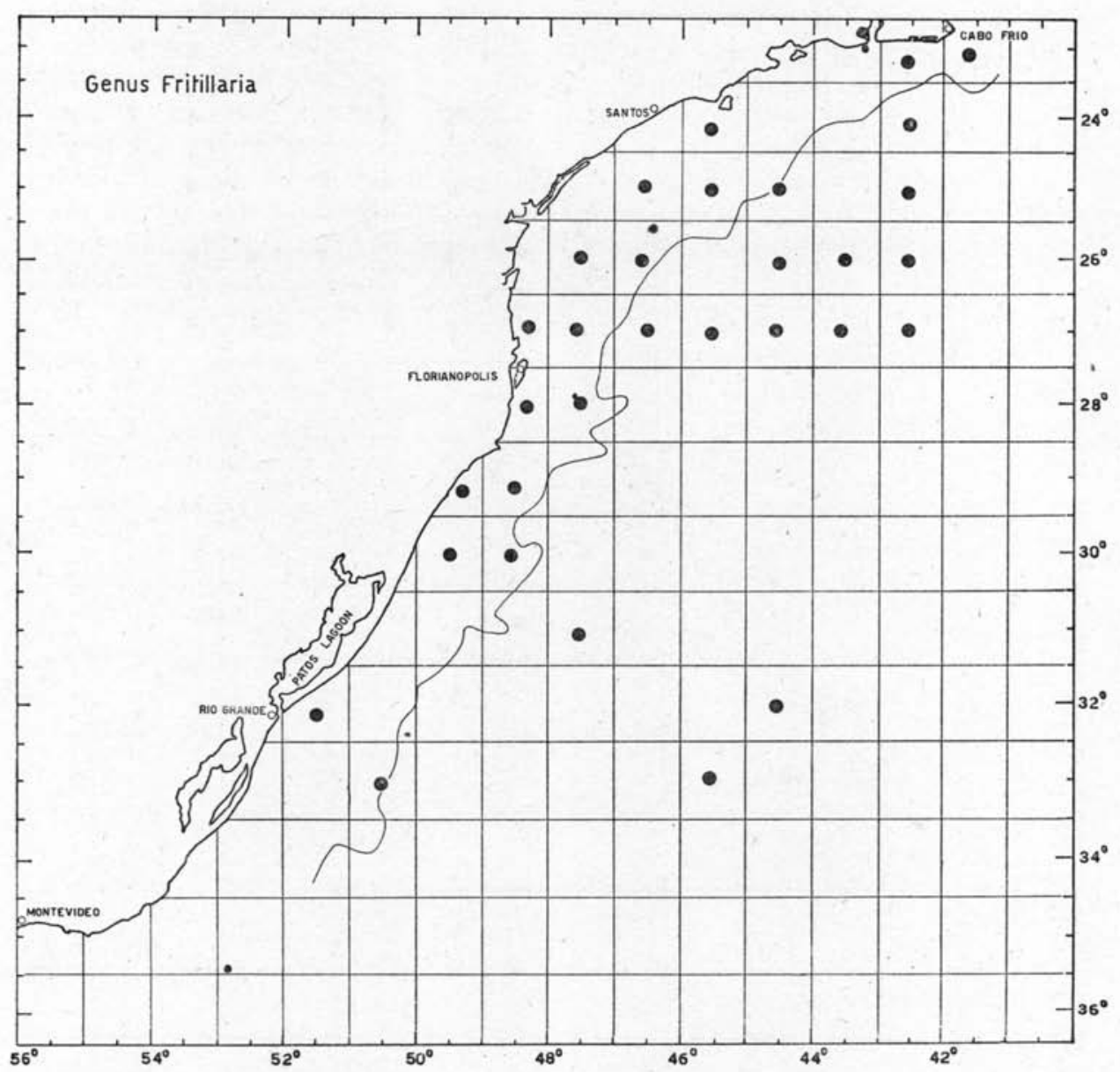

Fig. 2 - Distribution expressed as occurrence of genus Fritillaria in samples available for each $10^{\circ}$ square. $200 \mathrm{~m}$ contour

ture. It was noticed that when Fritillaria was more abundant, this was due only to two species, namely $F$. pellucida and $F$. haplostoma. As is known, these species may occur in swarms (Tokioka 1955, p. 253) when the greater number of descendants produced become crowded due to little or no turbulence. A favourable niche in the environment or biological attraction between individuals may also cause overdispersion (Morrison Cassie 1959b, p. 340). Considering the genus Fritillaria as a whole Lohmann \& Hentschel (1939, map 116) showed that the few species collected had different distributional maps. Between lat. $30^{\circ} \mathrm{S}$ and lat. $10^{\circ} \mathrm{S}$ values 
are intermediate. Centers of dispersion as well as the delimitation of cold and warm water populations in Fritillaria are better defined tsan in Oikopleura. The penetration of Fritillaria in coastal waters and its presence in sub-Antarctic waters, indicate a considerable temperature tolerance. However, the largest catches were made in oceanic waters, suggesting that the genus may occur there more frequently than previously thought (Udvardy 1954). The general occurrence of a smaller number of fritillarids than oikopleurids was interpreted by Lohmann (1931, p. 27) as their being missed in sorting plankton due to their small size and transparency.

Fig. 3

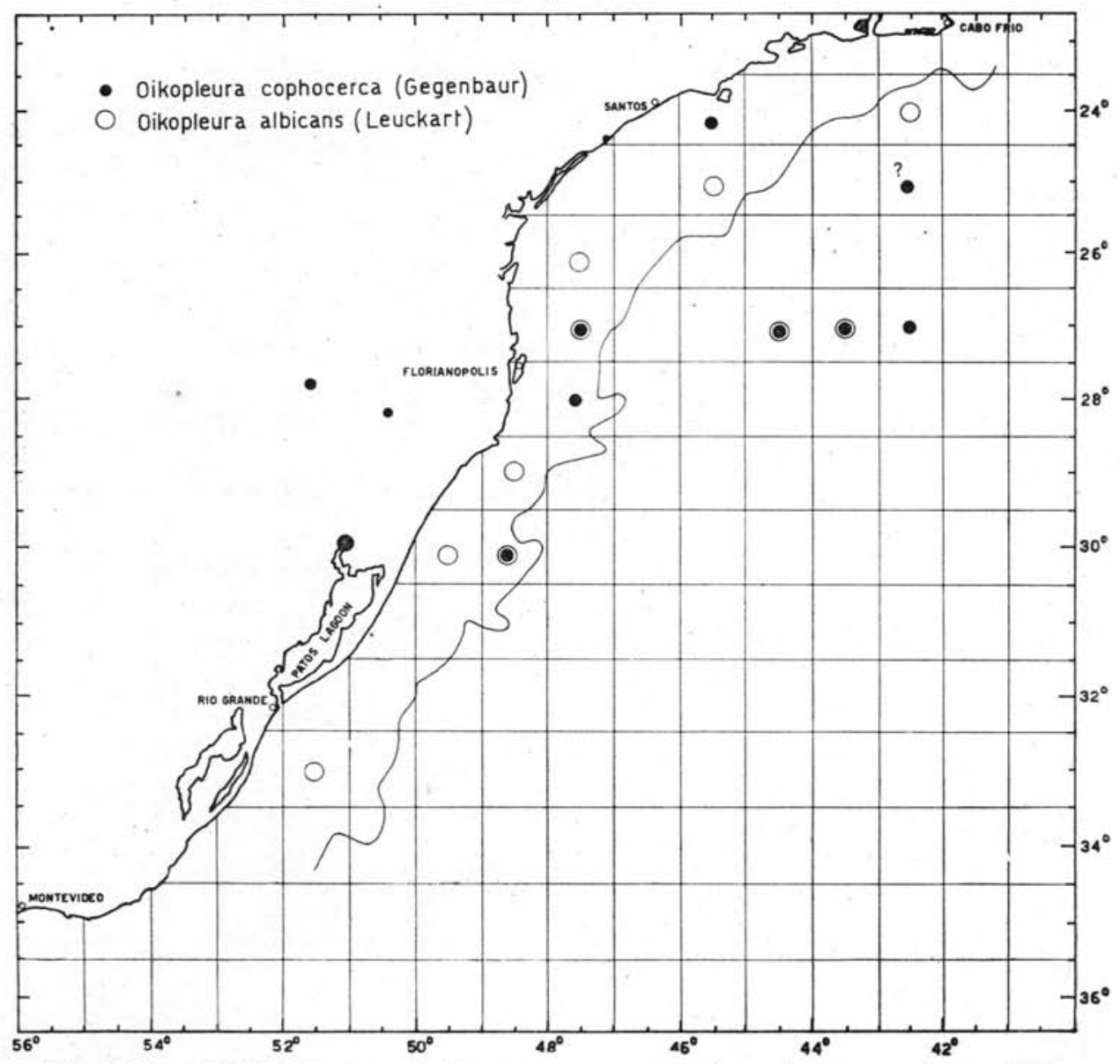

Fig. 3-14 - Distribution expressed as occurrence of each species in samples available. $200 \mathrm{~m}$ contour 
b) Distribution of the species - The general spectrum of environmental requirements for each species was taken from Forneris (1957).

Oikopleura albicans (Leuckart) (Fig. 3) - This circumtropical species, eurythermic and with salinity range between 33.00 and $37.40 \%$, is an oceanic species migrating towards the coast. It occurred in tropical and shelf waters. The greatest number was found in warm tropical waters (Sta. 47 of 'Iguatemy'). It was also abundant at Sta. 82 of 'Solimões' where the haul sampled different layers. Widely distributed, mainly in tropical waters but rare.

Oikopleura cophocerca Gegenbaur (Fig. 3) - This species was considered as a synonym of $O$. albicans but both are ana-

Fig. 4

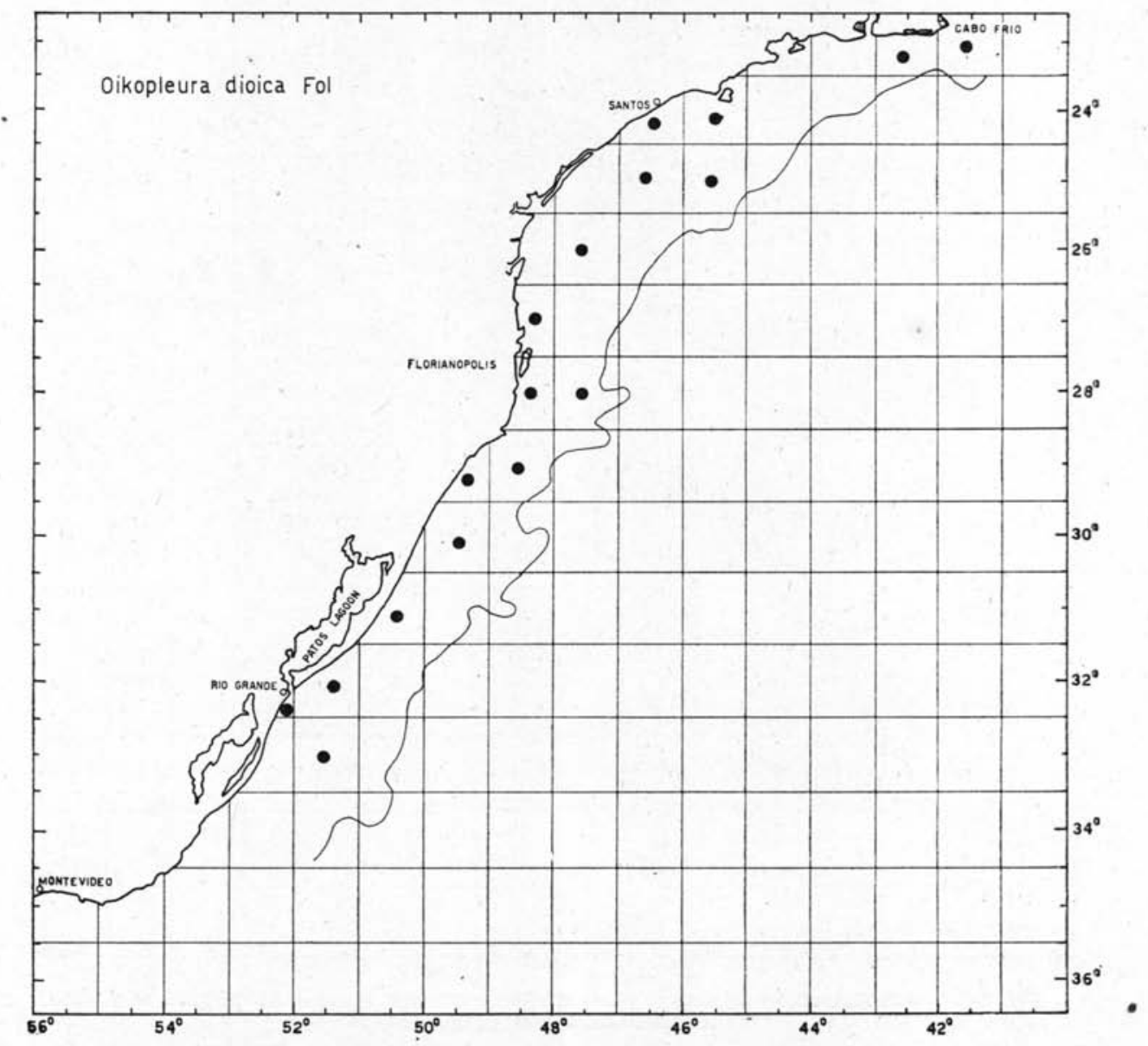


tomically quite different. They show nearly the same environmental preferences. Oikopleura cophocerca occurred in tropical as well as in shelf waters and may disperse towards the coast. Greatest numbers were found in tropical and in mixed tropical/ shelf waters. One specimen occurred in coastal water (Sta. 32 of 'Solimões') probably as an immigrant. This species is important in the transition region to cool waters.

Oikopleura dioica Fol (Fig. 4) - Mainly considered as a thermophile eurythermic and euryhaline species inhabiting neritic environments. It tolerates a wide range of salinity and temperature. Although considered a typical neritic species it avoids - certain coastal waters (Russell \& Colman 1935, p. 228; Björnberg \& Forneris $1956 \mathrm{~b}, \mathrm{p}$. 114) perhaps only seasonally. In the present material it occurred over the shelf and was especially abundant in shelf waters. It enters coastal waters, lives well there but does not dominate; however it was the dominant species at Sta. 19 and 24 of 'Presidente Vargas' but due to the small number of appendicularians present this fact has no significance at all. The one specimen referred to Trindade Is. (Björnberg \& Forneris 1955, p. 30) indicates the presence of small streams of shelf water there and in the region of Jaseur Bank the species might indicate shelf or coastal influence as already mentioned (Björnberg \& Forneris 1958, p. 84). It occurred also at $100-50 \mathrm{~m}$ depth but disappeared at stations beyond the edge of the shelf. The findings of the 'Meteor' (Lohmann \& Hentschel 1939, map 98) indicate a southern population of $\mathrm{O}$. dioica extending from lat. $20^{\circ} \mathrm{S}$ to about $45^{\circ} \mathrm{S}$ with a maximum of occurrence in the zone under the influence of the La Plata River (p. 160). Mature individuals were found at all seasons; they were especially numerous in shelf waters of low temperature (about $18^{\circ} \mathrm{C}$ ) and in the area studied the species may represent a temperate zone population (cf. also Lohmann \& Bückmann 1926, p. 145 and Thompson 1948, p. 39).

Oikopleura fusiformis Fol (Fig. 5) - The two forms of this species, namely typica and cornutogastra occurred. It is a thermophile species which tolerates a broad spectrum of each of the environmental requirements considered here. On the whole it resembles closely $O$. longicauda in its distribution. The forma cornutogastra is not as conspicuous in its occurrence as the forma typica (see Björnberg \& Forneris 1955, p. 33). Its greatest frequency was in shelf waters with temperature greater than $20^{\circ} \mathrm{C}$. Juvenile specimens seem to prefer coastal waters but they are highly eurythermic. According to Tokioka (1960, p. 377) the forma cornutogastra is a lagoon water inhabitant on the tropical Pacific. The forma typica was found in all types of waters sometimes in high frequencies but it is not so abundant in number as o. longicauda. The highest numbers came from shelf waters with 
Fig. 5

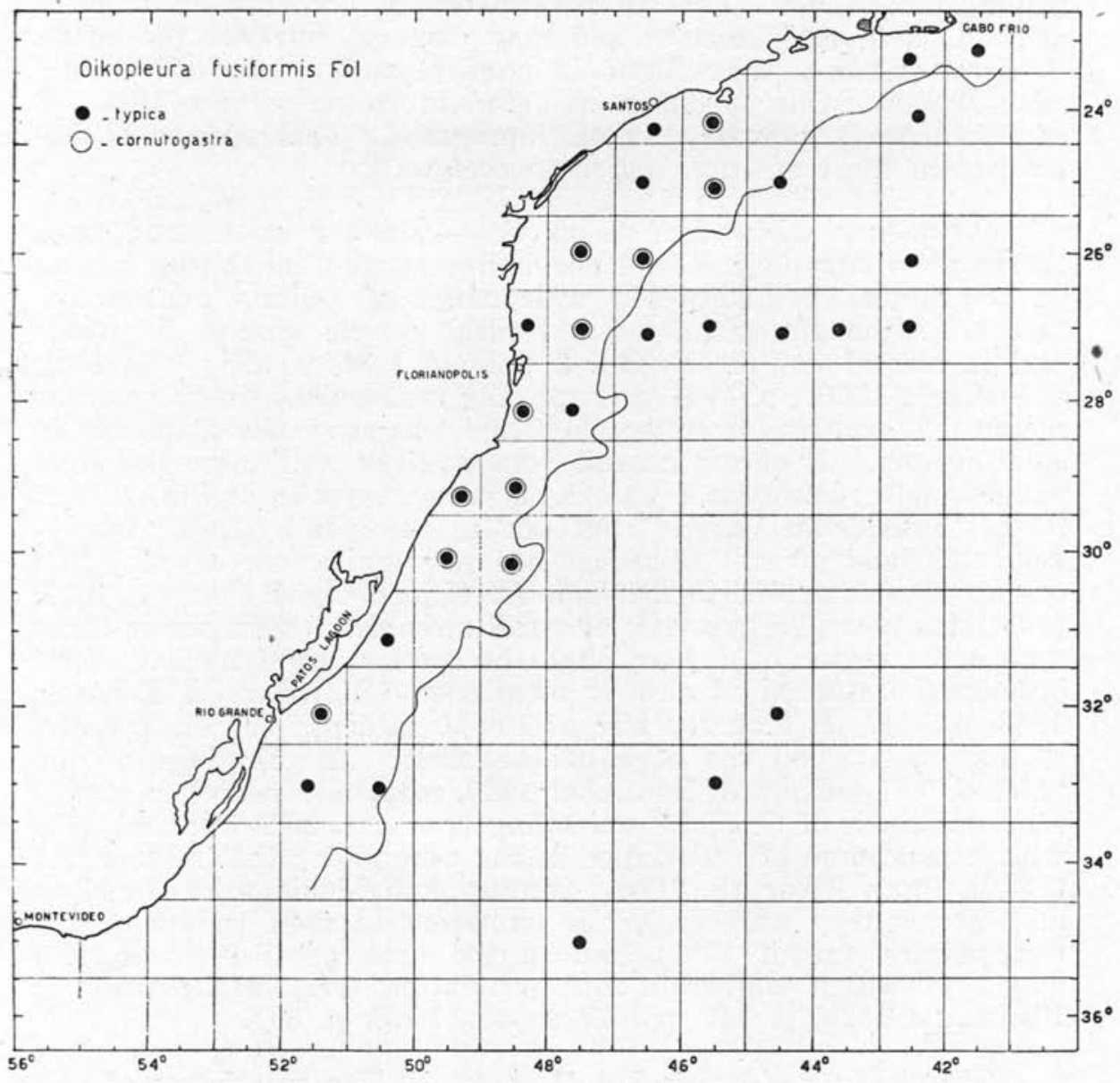

temperature greater than $20^{\circ} \mathrm{C}$. In coastal waters under the influence of Patos Lagoon the forma typica was also numerous. The present data indicate that this form prefers high salinity combined with high temperature and diluted waters having low temperature. Only disintegrating individuals occurred under $50 \mathrm{~m}$ depth. Mature and young specimens occurred at all seasons. The results of the 'Meteor' (Lohmann \& Hentschel 1939, p. 164) suggest that this species is predominantly bound to the shelf and the highest number was also found in the region here considered. As in the case of $O$. dioica we may consider the present population as a cool temperate zone one, occurring from about lat. $50^{\circ} \mathrm{S}$ to about lat. $20^{\circ} \mathrm{S}$ (cf. Lohmann \& Hentschel op. cit., map 101). 
Oikopleura gracilis Lohmann (Fig. 6) - This species is anatomically very similar to $O$. longicauda and it can be mistaken easily for this species. It is considered as eurythermic, euryhaline

Fig. 6

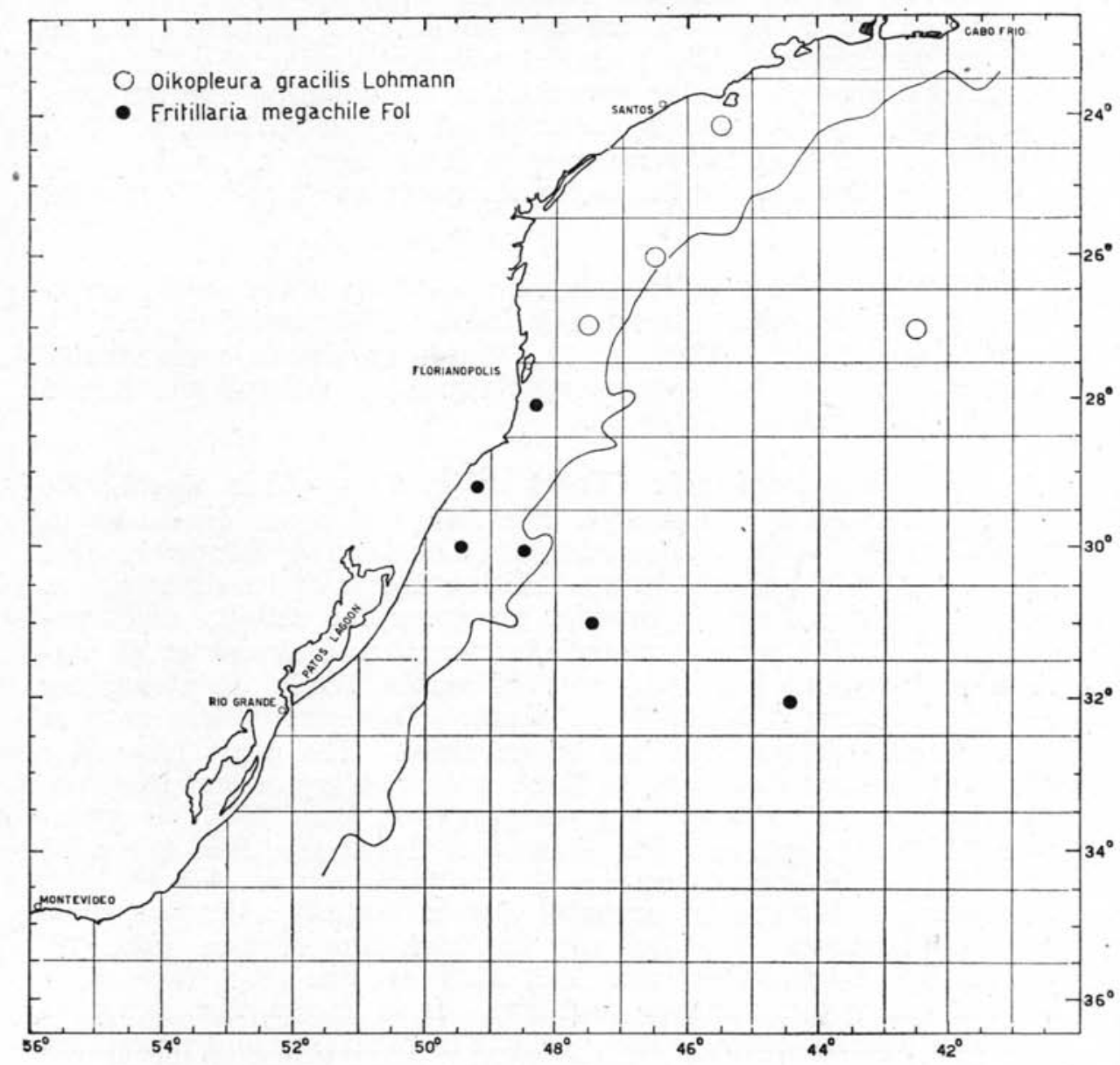

and panthalassic. A rare species found in tropical and shelf waters, as well as in sub-tropical waters of the 50-100 m depth layer (temperature range between 12.48 and $17.53^{\circ} \mathrm{C}$ and salinity greater than $35 \%$ ). Lohmann \& Hentschel (op. cit., p. 156) considered this species as oligotrophic and recorded it from the region here considered (map 96). 
Oikopleura graciloides Lohmann - Probably this and the preceeding species are one and the same, not previously distinguished by some authors (Lohmann \& Bückmann 1926, p. 149). Eurythermic thermophile species occurred only once at Sta. 82 of 'Solimões'. At this station the haul sampled different salinity layers and it is impossible to fix the preference of the species. The temperature of the different layers matches the spectrum of tolerance of the species. There are no data in the literature on salinity preferences. The material collected during the 'Meteor' Expedition showed similar geographical distribution for the present species and $O$. gracilis (Lohmann \& Hentschel 1939, p. 158). Bückmann (1924, p. 205) referred to it as occurring in the halostase of the South Atlantic, in the Benguela and South Equatorial Currents.

Oikopleura intermedia Lohmann - This thermophile eurythermic and euryhaline species is hardly differentiated from $O$. longicauda (Tokioka 1940, p. 3). Some specimens were doubtfully referred to this species, specially from coastal and mixed coastal/shelf waters (Table I).

Oikopleura longicauda (Vogt) (Fig. 7) — This world-wide distributed species is characteristic and sometimes dominant in tropical warm waters. According to Lohmann \& Hentschel (op. cit., p. 161) temperature is the limiting factor of its distribution. O. longicauda presents a broader spectrum for salinity and temperature. In the present material it was found almost at all stations and appeared in all types of water. Only disintegrating specimens occurred below $50 \mathrm{~m}$ depth. This species was rare in pure coastal waters with low temperature. The great frequency of disintegrating specimens in these waters suggests that the combination low salinity-low temperature (less than $20^{\circ} \mathrm{C}$ ) is unfavourable for the species. Plankton from 'Iguatemy' Sta. 49 hauled at midnight in coastal waters of low temperature showed high frequency of this species probably due to vertical migration from deep shelf waters. Low salinity but high temperature (Sta. 19, $21,32,33$ of 'Solimões' and 105, 106) are the most favourable both to young and mature specimens. It is known that temperature and salinity combine their effects in confining and promoting distribution of species (cf. Kinne 1957; Simmons 1957; Vannucci 1963 , p. 160). Generally $O$. longicauda was more frequent in shelf waters; it was not so frequent in tropical ones. Mature and young specimens were found in all seasons. There are indications that this species is abundant in temperate waters in warm seasons and on the contrary in warm waters in cold seasons. In the Mediterranean however it is more abundant in the warm season (Bernard 1958, p. 225). 
Oikopleura rufescens Fol (Fig. 8) - This is a thermophile species strongly eurythermic and euryhaline. It was considered earlier as an indicator of northern waters (Björnberg \& Forneris

Fig. 7

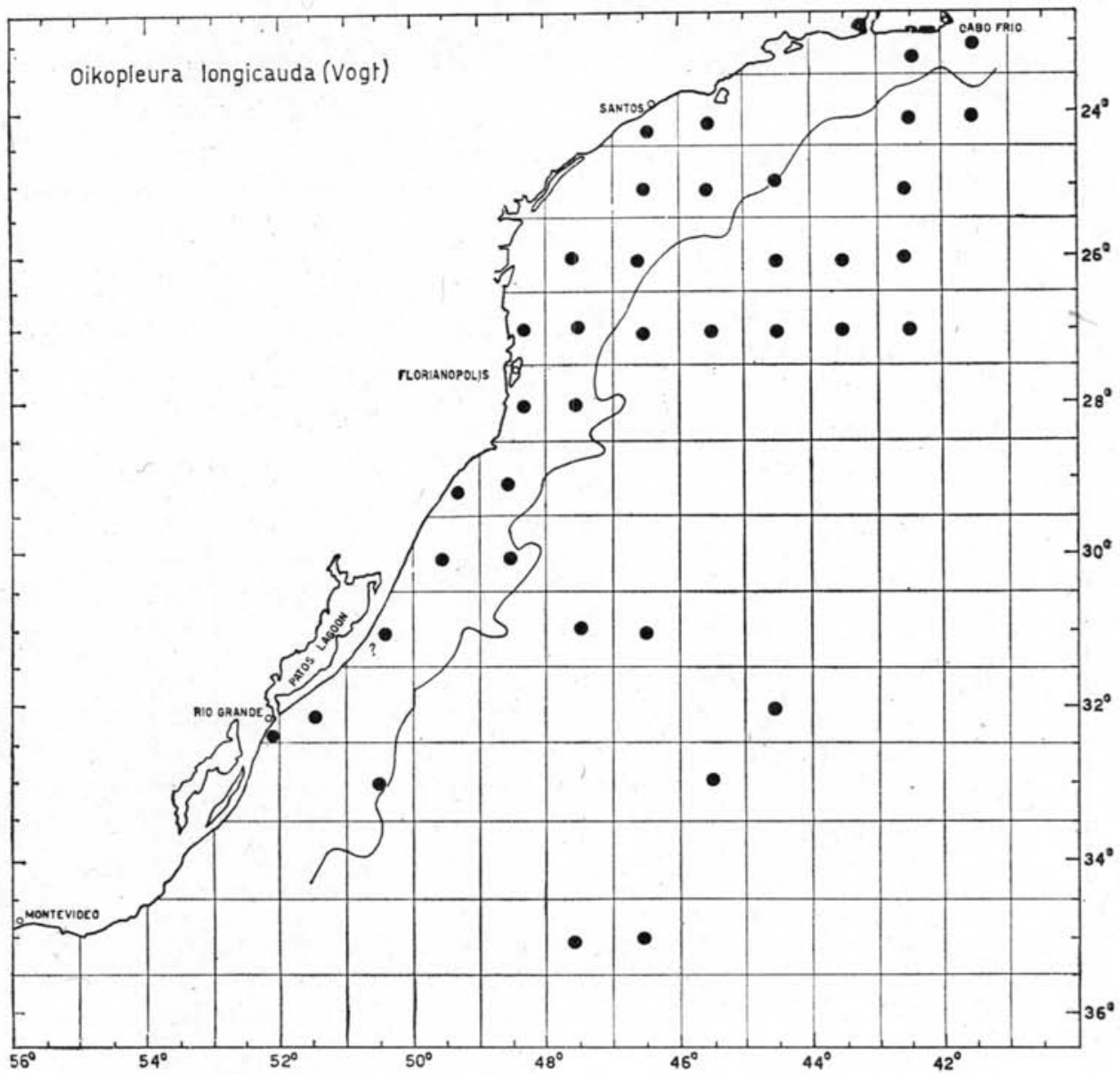

1956b, p. 114). However, the present data suggest that it has a wide distribution occurring in all types of waters but more frequent in shelf waters and rare in tropical ones. Mature specimens occurred at all seasons. Only mature specimens were found below $50 \mathrm{~m}$ depth. The distribution map of the species given by Lohmann \& Hentschel (1939, map 100) shows that in the area here studied $O$. rufescens represents a temperate zone population with a center of dispersion around Patos Lagoon. 
Stegosoma magnum (Langerhans) (Fig. 9) - Circumtropical, thermophile eurythermic species found in tropical shelf and in mixed tropical/shelf waters. Some specimens were found in a

Fig. 8

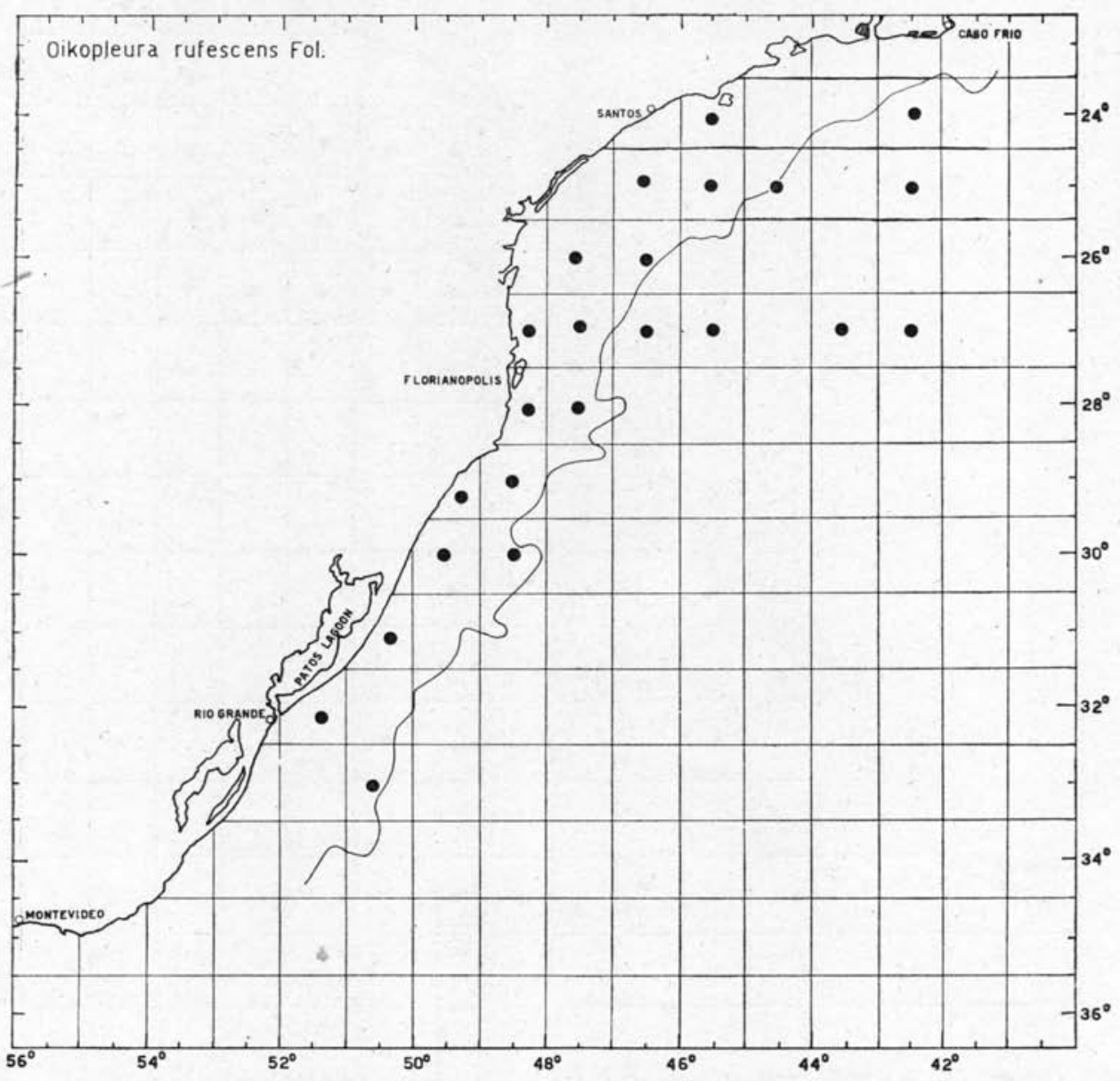

region under the influence of coastal waters, thus confirming its panthalassic nature. It never occurred at temperature lower than $18^{\circ} \mathrm{C}$. However, a great number was found in cooled tropical waters (about $18^{\circ} \mathrm{C}$ ). Lohmann \& Hentschel (1939, p. 172) records high numbers of this species in southern Brazilian waters (cf. map 107). 
Fig. 9

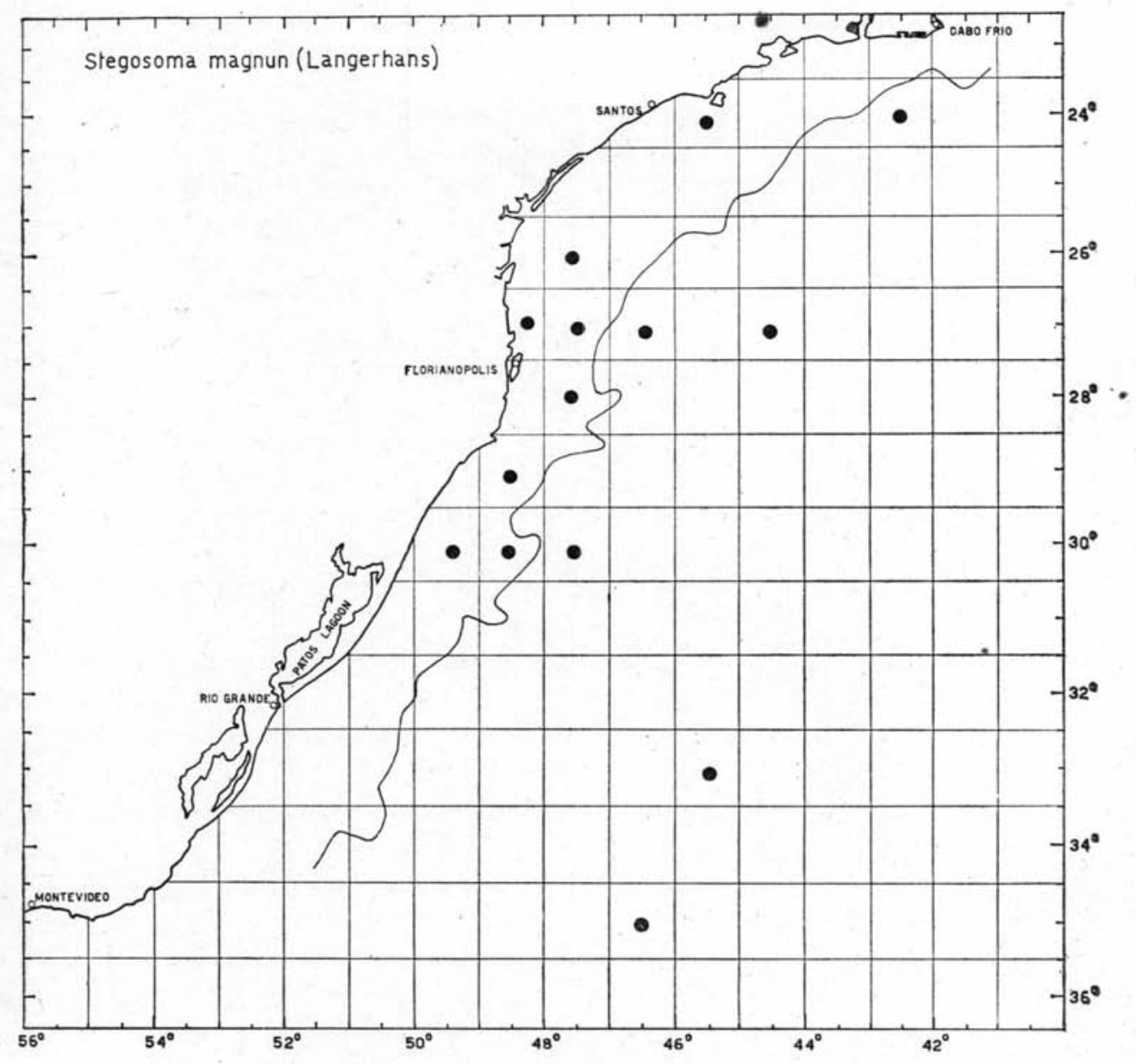

Fritillaria borealis Lohmann (Fig. 10) - This species with a high degree of morphological instability (Lohmann 1905; 1931; Tokioka 1940 , p. $10 ; 1950$, p. 155) occurred in its forms intermedia, crassa and sargassi. The biological meaning of these forms as well as their true environmental requirements are unknown. The cause of the differentiation of this species at the taxonomical level of forms may be environmental, genetical or both (Strohl 1936, apud Friederich 1955). Certainly f. typica and f. sargassi are reproductively isolated from one another and hybridization does not take place at the boundary areas of the two forms. Tokioka $(1960$, p. 363) suggested that f. intermedia might represent 
Fig. 10

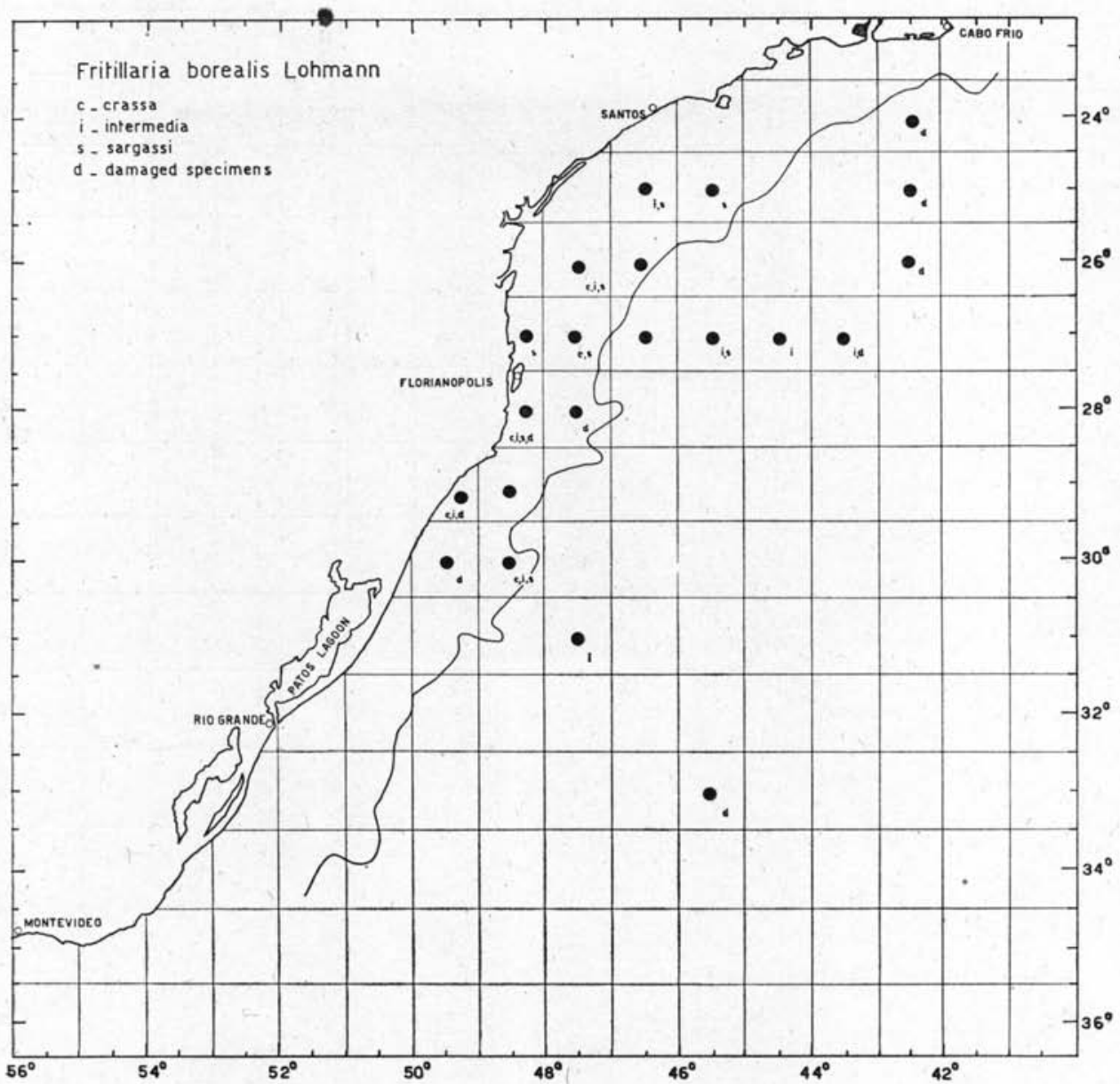

a population of f. typica occurring in mixed and warm waters. Fritillaria borealis in a broad sense is a cosmopolite with an unusually large milieu spectra (temperatures ranges: -1.90 to $29.30^{\circ} \mathrm{C}$ and salinity ranges: 6.00 to $37.00 \%$ oo ). However there are indications that each particular form has a somewhat definite location within this wide spectrum. Thus f. typica is a cryophile while f. sargassi is a thermophile. The needs of $f$. intermedia and f. crassa are unknown, a fact probably linked to the scarcity of occurrences. Fritillaria borealis was collected especially in tropical waters, revealing no preference for temperature. Forma sargassi was more frequent in this water type. In shelf waters 
(temperature ranging from more than $19^{\circ} \mathrm{C}$ up to $21^{\circ} \mathrm{C}$ ) f. intermedia and f. crassa dominate, f. sargassi being rare. This is an oceanic form which may be swept into the coast, occurring in mixed waters of tropical and shelf origin. Few individuals of $f$. sargassi occurred in diluted waters, possibly as terminal immigrants. The southernmost occurrence of this form in the present material was at lat. $30^{\circ} 25^{\prime}$ 'S. Lohmann \& Hentschel (1939, p. 176) showed the $15^{\circ}$ isotherm as being the southern boundary of this form and refer to the region under the influence of the La Plata River as the zone of maximum abundance. The rare f. crassa occurred in shelf waters in November. It seems that this forma

Fig. 11

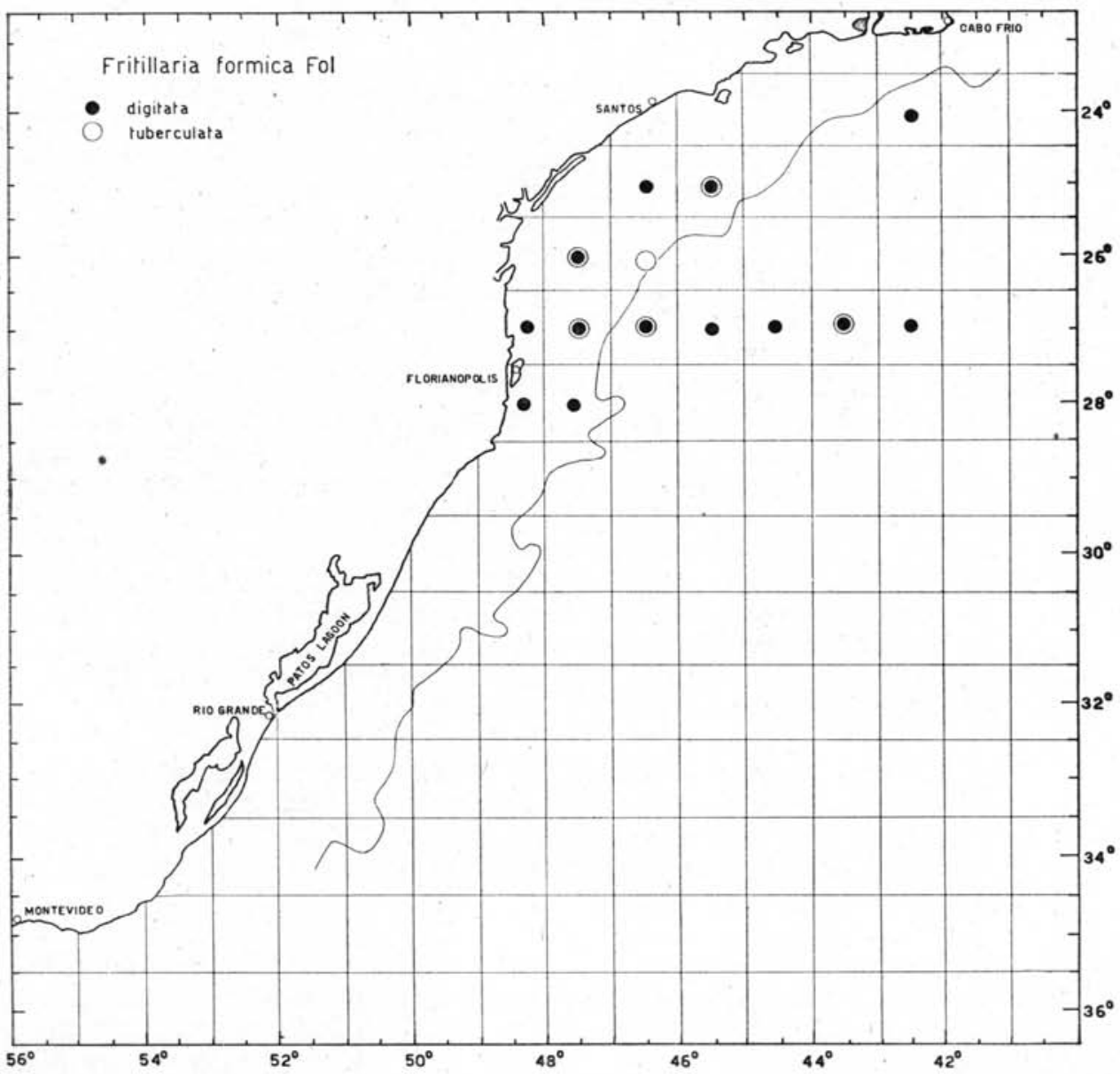


prefers cool waters as it was absent from waters of high temperature. Its presence over the shelf suggests that it is a southern form which probably found its optimum in cooler southern waters. Forma intermedia is considered to be a highly eurythermic (ranges: -1.80 to $28.20^{\circ} \mathrm{C}$ ) and a highly euryhaline species (ranges: 6.00 to $35.58 \%$ ). This form was most frequent in warm temperate shelf waters (temperature about $19^{\circ} \mathrm{C}$ and salinity around $35.52 \%$. Few individuals were found in tropical waters. Mature animals occurred in shelf waters and a single disintegrating specimen was also found in tropical waters (Sta. 43 of 'Iguatemy') indicating a possible limitation of that environment to reproduction. According to Lohmann \& Bückmann (1926, p. 169) f. intermedia decreases in number in warm waters. This form avoided coastal waters and may be considered as oceanic, in spite of being recorded from the Mediterranean coast of France (Vernières 1933, p. 42).

Fritillaria formica Fol (Fig. 11) - This thermophile species considered as eurythermic and panthalassic occurred in its two forms. Following Lohmann (1928, p. 67) forma tuberculata is bounded to the Mediterranean Sea and Polar water and digitata is distributed in warm oceanic waters. The southernmost occurrence of $F$. formica in the present material was at lat. $28^{\circ} \mathrm{S}$. Heaviest concentrations were noticed along mixed tropical and shelf waters (Sta. 46 of 'Iguatemy' and Sta. 3 of 'Presidente Vargas'). Both forms occurred at depths between 100 and $50 \mathrm{~m}$ and both in mixed waters. Specimens of digitata found in coastal waters, probably occurring there as immigrants, were disintegrating. Mature specimens were found in shelf as well as in tropical waters. No difference was noticed in the occurrence of the forms. According to Lohmann (1928) the distribution of the two forms is clearly separated, where one is abundant the other is rare. The findings of the 'Meteor' (Lohmann \& Hentschel 1939, p. 174) showed a rich population of formica in the area here studied. This population extending from the region of Abrolhos to the mouth of the La Plata River is a typically temperate zone one. It was also shown that the distribution of both forms was similar.

Fritillaria gracilis Lohmann - A rare euryhaline, panthalassic and sub-tropical species occurred only at Sta. 47 of 'Iguatemy' (surface temperature $21.08^{\circ} \mathrm{C}$; salinity $36.25 \%$ o. The present finding enlarges the southern occurrence of the species in the Atlantic up to lat. $27^{\circ} 19^{\prime} \mathrm{S}$.

Fritillaria haplostoma Fol (Fig. 12) - This thermophile species highly eurythermic and euryhaline is considered as panthalassic. It has a large spectrum for salinity and temperature requirements. In the present samples the species occurred in all 
Fig. 12

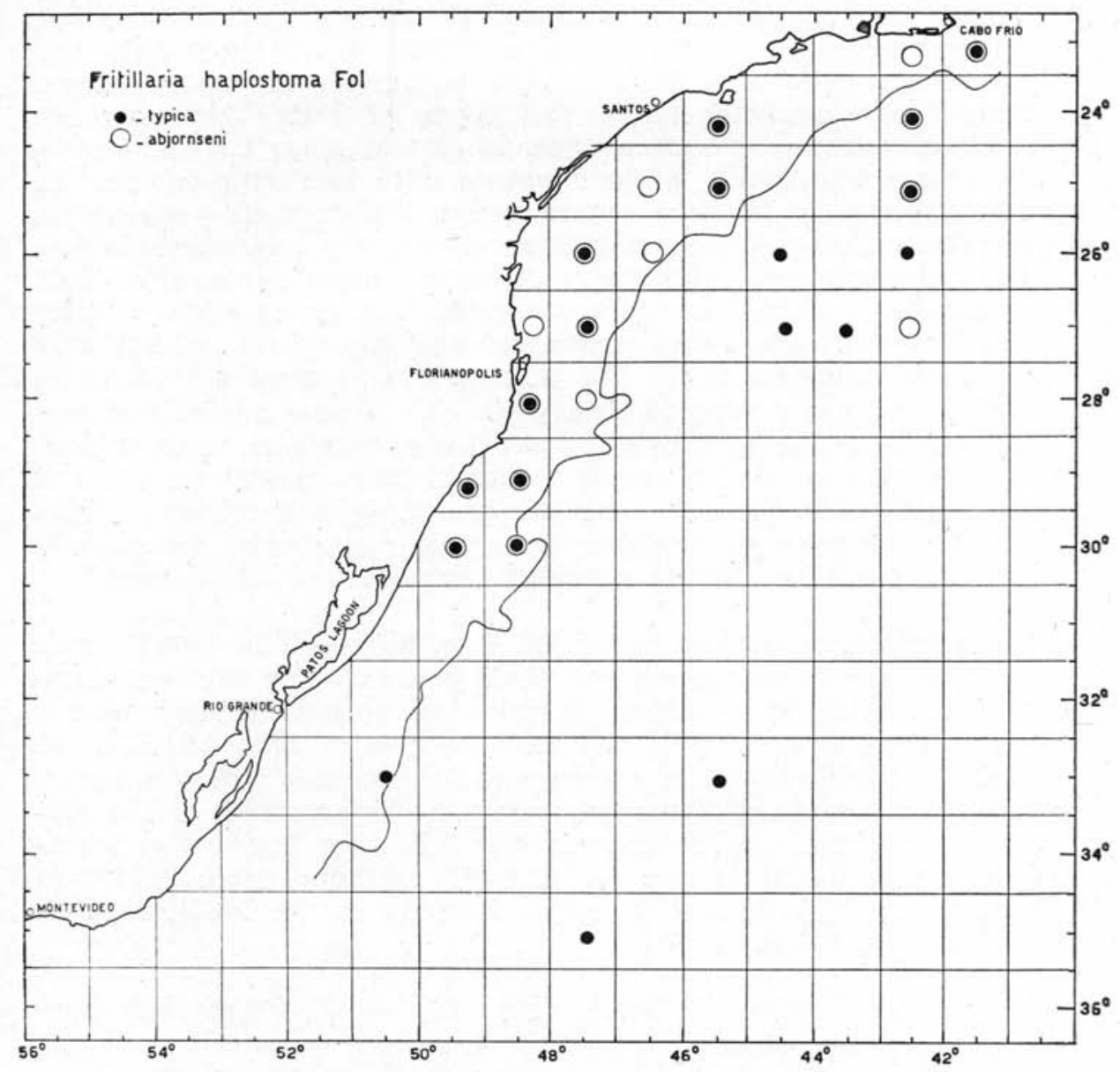

kinds of water. The greatest frequency in numbers was found in shelf waters of low temperature (about $19^{\circ} \mathrm{C}$ ). It was rare in pure coastal waters. The analysis of the data suggests that the species undergoes vertical migration because it was frequent in number in plankton hauled in the evening or at night and rare in plankton hauled at noon or in the afternoon. The two forms typica and abjornseni occurred, the former more frequent in oceanic waters and the latter in neritic environments (Björnberg \& Forneris 1955 , p. $59 ; 1956 \mathrm{a}$, p. 107). Although both forms have a broad distribution, they are rarely caught in large numbers. In the area here considered the species was found limited by the 
$15^{\circ} \mathrm{C}$ isotherm and a rich zone of occurrence was found north from the mouth of the La Plata River (Lohmann \& Hentschel 1939, p. 172). It is suggested that $F$. haplostoma is a tropical form but eurythermic; however, for Tokioka $(1960$, p. 373 and 415$)$ the main propagating area in Japanese waters is the neritic zone. Forma abjornseni occurred in all types of water but was not abundant, with one exception (Sta. 75 of 'Solimões'). The greatest number was found in shelf waters with low temperature. It was very rare in tropical waters where disintegrating specimens dominate. This suggests that these waters are unfavourable and that the species migrates there from the more favourable shelf and coastal waters. It prefers coastal waters of high salinity (around $34^{\circ} \%$ ) and high temperature (between 25.00 and $26.60^{\circ} \mathrm{C}$ ) but is not numerous there. Mature specimens were not found in samples collected during February-March. Forma typica was less abundant than the preceding form. Large numbers were noticed in shelf waters. It was rarely found in pure coastal waters and only represented there by mature or damaged specimens. This form indicated as panthalassic seems to occur only occasionally in coastal waters. Mature specimens occurred at all seasons.

Fritillaria megachile Fol (Fig. 6, p. 65) - This eurythermic species occurred in tropical and shelf waters. The greatest number was found in plankton sampled in cooled tropical waters (temperature around $19^{\circ} \mathrm{C}$ and salinity greater than $36 \%$ ). It seems to be a thermophile species and its presence indicates cooled tropical or mixed shelf/tropical waters. The spectrum of the species in the area studied showed the following boundaries: temperature from ?15.14 up to $21.34^{\circ} \mathrm{C}$; salinity from 35.52 to $? 36.80 \%$. It is absent in colder months in the Mediterranean Sea (Fenaux 1963a, p. 76).

Fritillaria pellucida Busch (Fig. 13) - A thermophile panthalassic species strongly eurythermic occurs in salinity ranging from 33.65 to $37.40 \%$. It prefers shelf waters, where it occurred in appreciable numbers but not in shallow waters. Rarely was it found in tropical waters. In depths of $50-100 \mathrm{~m}$ it was found in sub-tropical waters (temperature ranges: 12.00 to $17.00^{\circ} \mathrm{C}$ and salinity greater than $35.00 \%$ oo $)$. Essenberg (1922) suggested that when the surface temperature is higher than $17^{\circ} \mathrm{C} F$. pellucida migrates to deep waters. In the present material it also prefers surface waters. About 3,000 individuals were collected in coastal waters around Florianópolis (lat. $27^{\circ} 19^{\prime} \mathrm{S}$ - long. $49^{\circ} 13^{\prime} \mathrm{W}$ ). In two different seasons (June and November) the greatest numbers of the species occurred off Florianópolis and the high percentage of mature specimens suggest also that the reproductive zone and center of propagation are located there. This area includes Sta. 
48, 49, 50, 51 of 'Iguatemy' and Sta. 74, 75, 76, 78 of 'Solimões' all occupied in the shelf water mass with exclusion of Sta. 49 that was under the influence of the coast. The presence of large healthy

Fig. 13

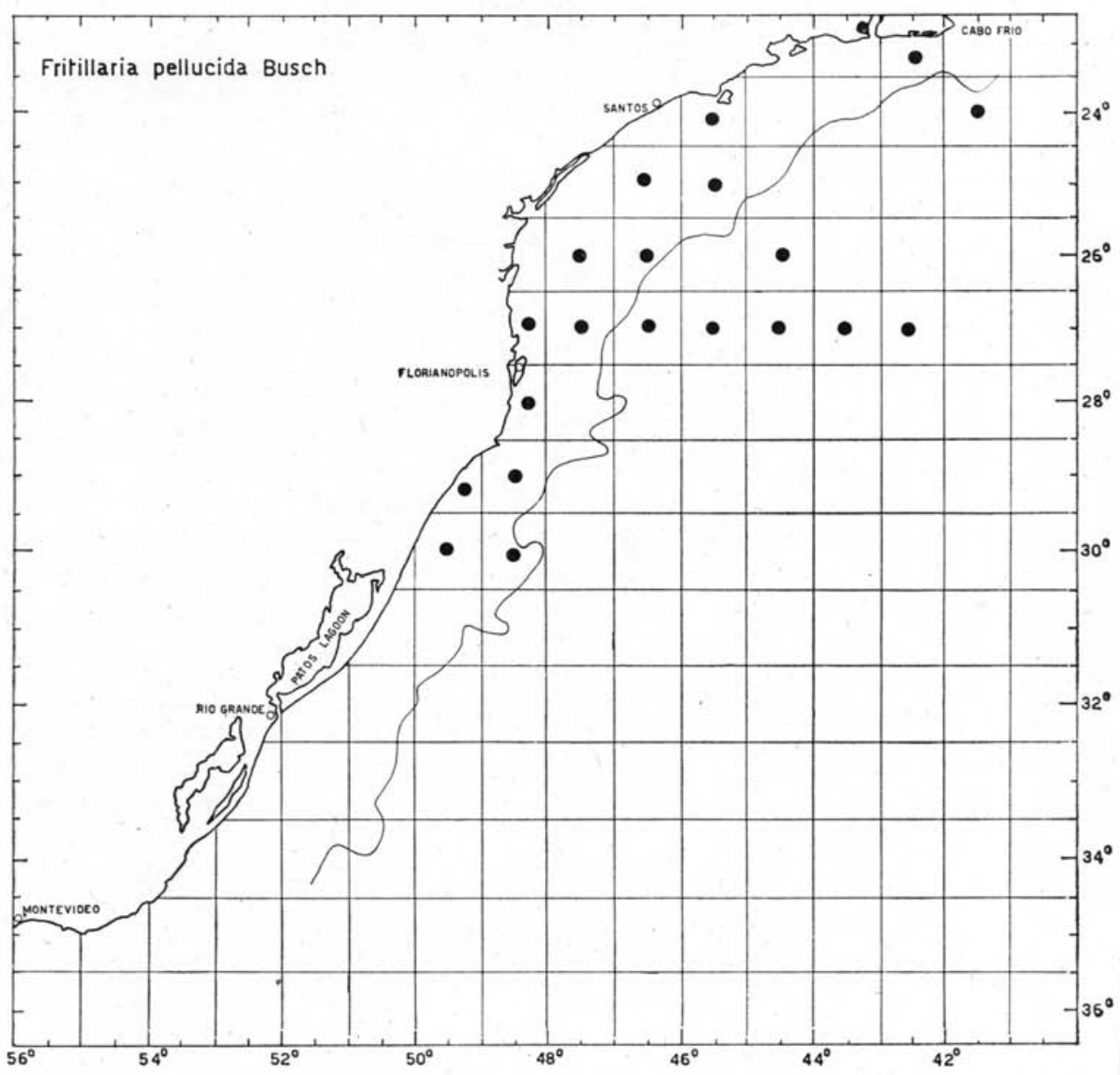

individuals without gonads indicates the possibility of successive maturation before death. The specimens found in tropical waters were all damaged or ghost animals. Lohmann \& Hentschel (1939, p. 172) referred to the species as limited in its distribution by the zone under the influence of the La Plata River waters and we can infer that this is a northern form. 
Tectillaria fertilis Lohmann (Fig. 14) - This species was considered as thermophile stenothermic of high temperature (22.00$27.15^{\circ} \mathrm{C}$ ) preferring high salinity $(35.20-37.00 \%$. Few numbers occurred in shelf waters and mixed tropical and shelf waters.

Fig. 14

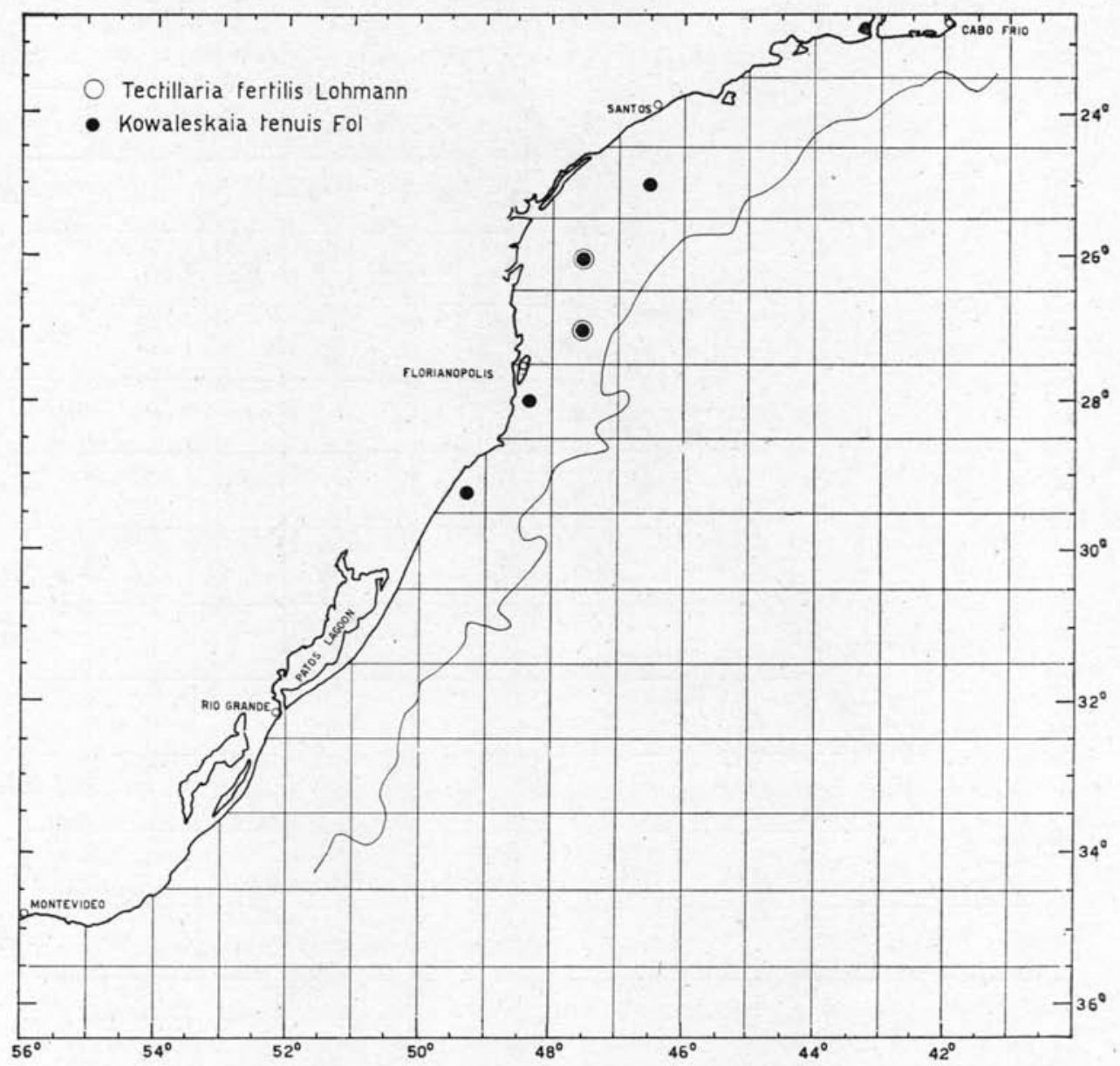

Probably it represents a tropical species but migrates into cool waters of about $19^{\circ} \mathrm{C}$. The present findings enlarge the temperature spectrum of this species, so that it now should be classified as being eurythermic. The southern boundary is now to be considered at lat. $27^{\circ} 19$ 'S (Björnberg \& Forneris $1956 \mathrm{~b}$, p. 114). 
Appendicularia sicula Fol - A eurythermic thermophile, euryhaline and panthalassic species. It shows a very large spectrum for temperature and salinity requirements. Sometimes very abundant (Lohmann 1896, p. 21; 1931, p. 43; Lohmann \& Bückmann 1926, p. 181) it was collected only once at Sta. 79 of 'Solimões' (surface, $19.46^{\circ} \mathrm{C}$ of temperature and $35.53 \%$ of salinity) in shelf waters. It was not collected in coastal waters but it is recorded as neritic, especially estuarine (Tokioka 1960, p. 378). Lohmann \& Hentschel (1939, p. 180) showed an enrichment in abundance of the species north of the mouth of the La Plata River where it might occur in swarms.

Kowaleskaia tenuis Fol (Fig. 14) - A thermophile eurythermic species. It occurred in temperatures ranging from 19.00 to $23.00^{\circ} \mathrm{C}$ and salinities from 35.16 to $35.70 \%$. In the present material it was found in surface hauls of cooled shelf waters. The northern boundary of the species with the present findings is enlarged up to lat. $29^{\circ} 27^{\prime} \mathrm{S}$.

Tails - The present collection of plankton samples showed high numbers of isolated appendicularian tails. Especially numerous were the tails in samples collected in shelf waters but the meaning of this fact is unknown. Also, the collections of the Plankton Expedition (Lohmann 1896, p. 4 and table on p. 88) showed some quantity of free tails. Essenberg (1926a, p. 515) reported that some enemies attack appendicularians at the trunk. It cannot be ascertained if that is the explanation for the present. findings. Some isolated trunks were also found.

\section{HORIZONTAL ZONATION AND GROUPS OF SPECIES}

Due to the fact that the area studied is a zone of oceanographic transition it was difficult to delimitate species to water masses. Endemic and steno-species restricted to the area were absent. There was no evidence of genuine cold water influence. The zone of convergence, frequently associated to sharp horizontal temperature gradients corresponds to the $15^{\circ} \mathrm{C}$ isotherm. Cryophile eurythermic appendicularian species whose ecological zone lies in the Antarctic and sub-Antarctic region did not transgress the Sub-tropical Convergence and therefore have their boundary southern of the area studied, in surface waters. It was almost impossible to distinguish indigenous species from visitors in order to account for mixing processes. Each of the abundant species has a large spectrum of environmental requirements and morphologically I did not endeavour to delimitate populations ecologically isolated within a species, so their special habits remain yet unknown. A decrease in number of species toward the coast, especially of fritillarids was noticed. Eleven species were found in 
coastal waters, 16 species in shelf waters and 13 in the tropical water mass. Oikopleura intermedia probably occurred but due to the uncertainty of the determination it was not considered in the present discussion of the horizontal distribution. Ten species, namely Oikopleura albicans, $O$. cophocerca, $O$. fusiformis, O. longicauda, O. rufescens, Stegosoma magnum, Fritillaria borealis, $F$. formica, $F$. haplostoma and $F$. pellucida were common to the three water types. However, O. albicans, O. cophocerca, S. magnum and $F$. borealis were very rare in coastal waters. Oikopleura dioica was absent in tropical waters and the rare species Tectillaria fertilis, Appendicularia sicula and Kowaleskaia tenuis were only found in shelf waters. Fritillaria gracilis was the only species found exclusively in tropical waters. Oikopleura gracilis and F. megachile were absent from coastal waters. Hentschel (1933, p. 151) and Björnberg (1963, p. 91) refer to the relationship between inconstancy of environmental conditions of coastal waters and variety of its communities. Coastal waters showed a reduced - number of species per sample (2 to 6) and almost no fritillarids. They are in general relatively poor in number of individuals and showed diversity of species groups. Twelve groups were found in coastal waters (Fig. 15, 16) eight of which exclusive of this water type. Oikopleura longicauda, O. dioica and $O$. fusiformis each may dominate in the coastal groups. $O$. dioica prevails (Fig. 15, Sta. 19 and 24) when temperature is low $\left(14\right.$ to $\left.17^{\circ} \mathrm{C}\right)$. Since the dominance of the species longicauda or fusiformis is frequent it was difficult to correlate this fact to physical properties of the 'water mass considered. At Sta. 49 of 'Iguatemy' (Fig. 16) an unusual group of nine species was observed in that Fritillaria pellucida dominated. Although this station is defined as a coastal water on the basis of the hydrographical parameters, the appearance of species characteristic of shelf waters suggests a movement of these waters towards the coast with a little dilution (salinity $34 \%$ ). The high relative abundance of adults at this station suggests that this is a special zone or center of propagation for the species pellucida (cf. Dumas 1907 apud Hesse et al. 1951, p. 293). Also, the great number of specimens found there may be due to the influence of water rich is nutrients (Hentschel 1933, p. 12). Species characteristic of coastal waters may be also found in great numbers in other environments since in the distribution of coastal as well as of offshore waters complex factors are involved (Garner 1959). Tropical waters showed a high degree of fluctuation in species number in opposition to earlier opinions (see Hardy 1936, p. 513) which referred to constancy in quantity and quality of plankton over wide areas of the tropics due to stability of conditions. The number of species of appendicularians varied from 1 to 10 per sample. In general we must consider both the season of sampling and the kind of tropical water, according to the different temperature/salinity combinations. In February, 
Fig. 15

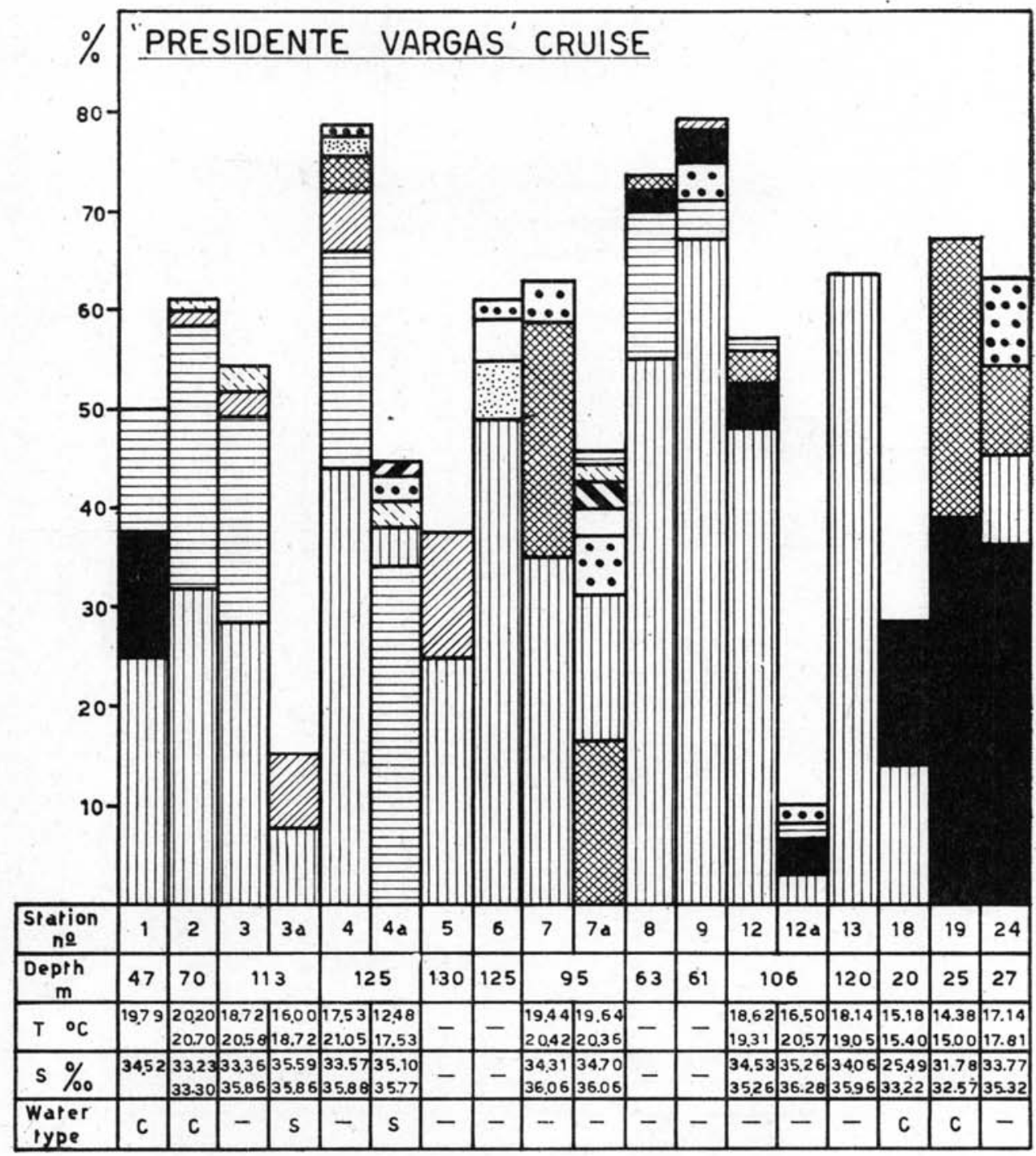

Fig. 15-18 - Histograms of groups of the most abundant species per station expressed as percentage of each species in the total appendicularian population. The species Oikopleura intermedia was not included as isolated species. c - coastal water s - shelf water

species number was smaller in waters with a salinity over $36.50 \%$ (from 1 to 5 per sample) than in water with salinity between 36.00 and $36.50 \%(9)$. On the contrary, in October-November samples with salinity over $36.50 \%$ bore the greatest number of 


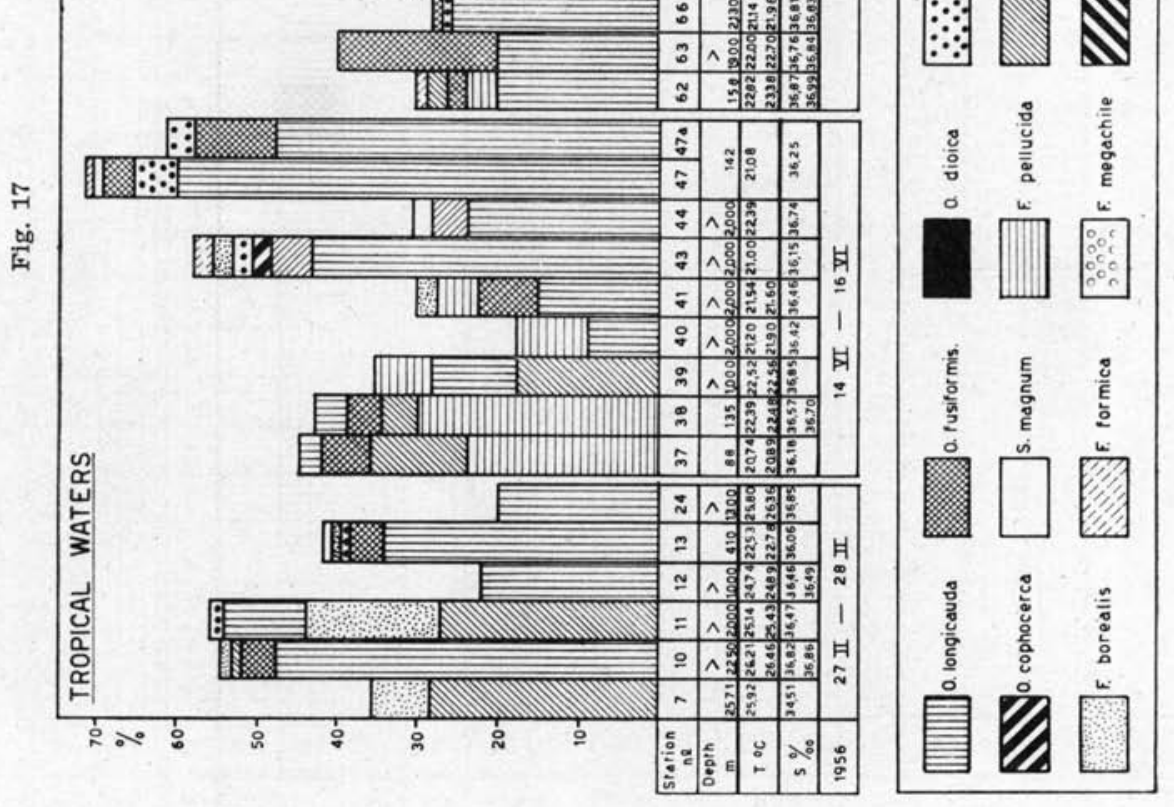




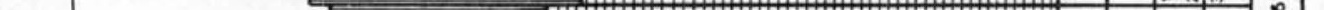


species (from 3 to 8 ) while June samples followed the pattern observed in February. In June fritillarids were scarce. The material sampled by the 'Meteor' presented a great number of species in tropical waters (about 15 species per sample). Also at Trindade Island a similar number was found (Björnberg \& Forneris 1955 , p. 4ff). Nineteen different groups of species were found exclusively in tropical waters (Fig. 17, Sta. 7, 10, 11, 13, 39, 41, $43,44,47,62,67-71,83,86,87$ and 89). Oikopleura longicauda, $O$. fusiformis and $F$. haplostoma, each may be dominant in these tropical groups, the latter in high temperature $\left(22\right.$ to $\left.25^{\circ} \mathrm{C}\right)$ and in salinity over $36.40 \%$, the former in a wide range of temperature/salinity combinations. Oikopleura fusiformis was dominant in cooled tropical waters with salinity from 36.20 to $36.40 \%$ and low temperature $\left(19^{\circ} \mathrm{C}\right)$ (Sta. 83 and 87$)$. Monotonous $O$. fusiformis group occurred in tropical waters with temperature of $21^{\circ} \mathrm{C}$ and salinity of $36.70 \%$ (Sta. 70). The number of species fluctuates highly in shelf water too.' They were poor in species in February (one to 5 per sample), when fritillarids were absent. No correlation could be inferred from a comparison between hydrographic data and number of species. High number of specirs (around 10) occurred especially in samples with salinity from 35,00 to $35.60 \%$. In general fritillarids were also less frequent in number than oikopleurids. June samples showed the highest number of species (average 6.8 species per sample) and all samples came from waters with salinity more than $35.50 \%$. The correlation between the number of fritillarids and oikopleurids fluctuates greatly. Five different groups of species occurred exclusively in shelf waters (Fig. 18, Sta. 48, 51-53, 54, 75, 77-81, 94). Oikopleura longicauda frequently dominates in these shelf water groups. Only occasionally $F$. haplostoma is the most abundant. The following groups of species were found to be common to two or three water masses:

a) Costal and shelf groups

1 - O. longicauda, O. dioica and F. pellucida (Fig. 15, Sta. 1; Fig. 18, Sta. 55).

2 - O. longicauda, O. fusiformis and F. pellucida (Fig. 16, Sta. 19 and Fig. 18, Sta. 107).

b) Coastal and tropical groups

1 - O. fusiformis, O. longicauda and O. rufescens (Fig. 16, Sta. 96; Fig. 17, Sta. 47a and 66). Oikopleura longicauda dominates in tropical water groups.

c) Tropical and shelf groups 
1 - O. longicauda and F. pellucida (Fig. 17, Sta. 40; Fig. 18, Sta. 48a and 50).

2 - F. pellucida, $F$. haplostoma, O. fusiformis and O. longicauda (Fig. 17, Sta. 37 and 38; Fig. 18, Sta. 74, 76, 78-80). This group occurred in tropical waters over shallow depths. In shelf waters this group showed dominance of $O$. longicauda, O. fusiformis or $F$. pellucida and different percentages of the species composing the group were observed.

3 - Monotonous $O$. longicauda group occurred generally in shelf waters of salinity under $35.50 \%$ and temperature under $22^{\circ} \mathrm{C}$ (Fig. 18, Sta. 23, 110-112). The tropical waters had a temperature of $18^{\circ} \mathrm{C}$ with salinity of $36.20 \%$ (Fig. 17, Sta. 84) and a temperature around $25^{\circ} \mathrm{C}$ with salinity greater than $35.50 \%$ (Sta. 24).

\section{d) Coastal, shelf and tropical groups}

1 - O. longicauda and O. fusiformis (Fig. 15, Sta. 12; Fig. 16, Sta. 32; Fig. 17, Sta. 63 ; Fig. 18, Sta. 57, 73, 108, 109). Sometimes $O$. fusiformis replaces $O$. longicauda but this occurred only where there was an inflow of shelf waters near the coast with an increase in temperature (Fig. 18, Sta. 2-4, 20).

Different groups of species in the same water mass were also found for the chaetognaths (Almeida Prado 1961, p. 33-35) ; conversely the same group of species was found in different waters. According to Vannucci $(1962, p .4)$ the nature of the water mass is greatly responsible for the qualitative variation of plankton. But the different groups occurring in the same water mass at the same period, due to the fact that species of appendicularian in groups change continually, confirm the view that waters considered to be hydrographically uniform for temperature and salinity are biologically different (Fraser 1939 ; p. 32 ff; 1961; Strickland 1963, p. 79). It is the complex of factors involved in the succession of plankton communities that determine the temporary state of a particular group of species of a water mass. Then it is not the location of the sample but the interplay of living/nonliving environment that is important (Vannucci 1957, p. 218; Bary 1963, p. 1527).

\section{ECOLOGICAL NICHE OF THE APPENDICULARIANS}

Yount (1958, p. 126) and Morrison Cassie (1957, p. 37) considered pelagic environment as poor in niches, due to uniformity of physical conditions and lack of shelter. However the diversity found in present studies in environments physically similar calls 
for the contrary (cf. Morrison Cassie 1959a, p. 398) and suggests the existence of different ecological spaces or units (Tonolli 1958, p. 138) in one water mass. Little is known about food requirements and enemies of the appendicularians. Lohmann (1909, p. 145), Willey (1915, p. 4), Bigelow (1926, p. 110) and Fenaux (1963a, p. 116) reported that they feed on unicellular elements of plankton. Species that occupy the same niche simultaneously might function as selective feeders, a view that is supported by the different anatomical features for capture of food. Competition is also avoided by layered distribution (David 1961, p. 15), stratification occurring also in superficial homogeneous waters (Banse 1955 , p. 15), different species and the same individuals of a species occurring at different levels (Lohmann \& Bückmann 1926, p. 185; Moore \& O'Berry 1957, p. 297 ff; Alvariño 1964, p. 72). Medusae, copepods (Essenberg 1926a, p. 515) and fishes (Radovich 1952, p. 580 and 583 ; Shelbourne 1953 , p. 151 ; 1962) are referred to feed upon appendicularians. Since the following observations on predation upon different species of appendicularians were obtained from fixed samples, a certain amount of inaccuracy is possible. The medusa Liriope tetraphylla (Cham. \& Eysen.), siphonophores, Penilia avirostris Dana, the copepods Oncaea sp., Corycaeus sp., Sagitta enflata Grassi and S. serratodentata Krohn were found biting $O$. longicauda. This species was found inside Doliolum denticulatum Q. \& G. and Thalia democratica (Forskal). Liriope tetraphylla, the acoel Convoluta sp., Sagitta bipunctata Q. \& G. and $S$. enflata were found attached to $O$. fusiformis. One specimen of Salpa fusiformis Cuvier had a $O$. fusiformis in the brancnial chamber. Sagitta enflata seized upon O. rufescens and S. magnum, $F$. borealis sargassi and $F$. pellucida. This latter species was bitten also by Oncea sp. and frequently in more than one sample by ostracods. There is a preference for predation on mature animals; both tail and trunk and occasionally houses are eaten.

\section{DIURNAL MIGRATION}

Lohmann (quoted from Hensen 1911, p. 340) indicates that appendicularians migrate because their food is limited to a particular depth. An attempt has been made to determine from the present material if there were some differences in abundance between day and night hauls. Therefore total number of surface samples at night stations were compared with total number of diurnal ones. Stations located over the shelf varied greatly in both night and day hauls, in total number as well as in number of the most abundant species. At the same hour samples with a maximum and minimum number of specimens were found. This may be due to the different seasons and methods of sampling used. However, analysis of data of surface plankton collected over great depths showed some rhythmic fluctuation. Four maxima of abun- 
dance at $0300,0900,1500$ and $2200 \mathrm{~h}$ were observed due especially to the species $O$. longicauda and $O$. fusiformis that showed equivalent rhythms. Fenaux (1961) also found a rhythmic distribution of the abundance of appendicularians in surface waters. Bary (1960, p. 119 and fig. 23) found one maximum for O. dioica and "two for $O$. fusiformis during a day period. Russell \& Colman (1935) report that appendicularians migrate to near the surface between 2100 and $2325 \mathrm{~h}$ and sink during day-time to about 10 metres depth. Also migration was restricted to the layers between the surface and $25 \mathrm{~m}$ depth (Fenaux 1963a). Therefore it appears difficult to distinguish between aggregation and concentration of individuals due to diurnal migration.

\section{MORPHOLOGICAL NOTES}

It is known (Fol 1872, p. 460; Essenberg 1926b; Lohmann 1933) that appendicularians can show different degrees of disintegration before death. Mature specimens are rarely found complete, disintegrative processes beginning at the anterior parts of the trunk. The alimentary canal and the tail persist longer. Thompson (1948, p. 445) and Udvardy (1954; 1958) showed a correlation between disintegration and environmental changes, due especially to mixing processes. Specimens designated here as ghosts showing only the body contour and tail were sometimes abundant especially within the genus Fritillaria. Appendicularians vary greatly both morphologically and in size (Tokioka 1951; 1956). As far as variability is concerned Fritillaria is more plastic than Oikopleura. The shape of the ovary and testes varies greatly in some species as noticed earlier by Lohmann (1931). Various forms of $F$. borealis were defined according to the shape and position of the gonads. However, such features are insufficient due to the great variability of gonad shapes and to the way in which they undergo fragmentation which is varied and not arranged in a serial sequence. It is possible that a fragmentation of the gonad occurs before the discharging of the genital products. Oikopleura longicauda showed decay processes accompanying maturity, disintegration taking place in the anterior part of the trunk. Some young individuals already showed traces of disintegration. Ghost specimens occurred. Isolated sex cells were noticed in the tail. Specimens of Sta. 5 of 'Solimões' (mixed waters) bore epiparasites on the tail. Full grown healthy individuals without gonads from tropical and coastal waters suggest that reproduction takes place more than once before death and genital products are discharged by the posterior dorsal part of the trunk. However, Fenaux $(1963 a$, p. $92 ; 1963 b$, p. 636) reports for this species several reproductive cycles and reproduction accompanied by the death of the individual. In some samples there 
were free digestive knots. Disintegrating mature specimens of $O$. albicans were found; however, Fenaux (1963a, p. 133) reports elimination of genital products by sperm ducts. There are indications that $O$. cophocerca matures more than once. Young mature isolated trunks of $O$. dioica as well as free digestive knots occurred. Some specimens were found inside the house and some had only one pair of subchordal cells. From $O$. fusiformis free digestive knots, specimens inside the house, disintegrating and ghost ones occurred. There are indications that this species also reproduces more than once. Fol $(1872$, p. 472$)$ refers to the high degree of disintegration accompanying reproduction in $O$. rufescens. Free sex cells occurred inside the tail of specimens of that species and free trunks and digestive knots and ghosts were found. Disintegration accompanies maturity in S. magnum. Isolated digestive knots with attached tail and also specimens inside the house occurred. Some mature animals of $F$. pellucida had only the body contour with the ovary placed anteriorly and testes broken down. This suggests protandrous maturity. Ghost specimens were commonly found. Disintegration following maturity may occur in $F$. haplostoma. Specimens having only an ovary were noticed and specimens with eggs scattered throughout the body cavity and still complete testes suggest a protogynous hermaphrodite. Probably specimens reproduce more than once; ghosts and individuals with anomalous gonads were found. Great number of specimens of $F$. borealis showed no gonads, disintegrating processes, ghosts and individuals with only ovaries occurred. Mature individuals with testes dissolved showed protandry. Specimens of $F$. digitata showed amphichordal cells on the tail and irregular gonads. Disintegration accompanies maturity in Tectillaria fertilis while individuals of Kowaleskaia tenuis possibly reproduce more than once. Ghosts of the latter species occurred.

\section{CONCLUDING REMARKS}

The distribution of species and group of species according to environment seems to reflect the influence of a complex of factors, like temperature/salinity combinations, mixing, and local factors especially in inshore areas. Biological interactions are of great importance. The faunal change is generally associated to a complex gradient of factors both hydrographical and biological. The loss of elements through changing conditions and introduction of elements migrating from lower layers or from mixing may be involved. The study of pure water masses as well as of the transformations they suffer when displaced to other areas certainly will help to understand the different patterns observed. The poorest waters in number of species are in general those from coastal stations, but some habitats of tropical and shelf waters showed also only one or few species. The greatest diversity of groups 
occurred in tropical waters, next in coastal waters and finally the smallest number occurred in shelf waters. The same species may inhabit one, two or three water masses, thus entering several groups.

\section{S U M M A R Y}

The distributional pattern of plankton organisms is the result of the complex interplay of factors both abiotic and biotic. The differential distribution of appendicularian species was analysed in relation to the environmental factors, temperature and salinity. The results suggest that the physical properties analysed are less important for the explanation of the observed distributions than the knowledge of the history and biological dynamics of the water masses. The area studied extending from about lat. $23^{\circ} \mathrm{S}$ to about lat. $36^{\circ} \mathrm{S}$ represents a transitional zone characterized by mixing processes and instability with strong gradients, especially of temperature and salinity. Only modified and mixed water masses having lost their primitive characteristics were found and this has a bearing on the absence of the steno-oecus species. The majority of the appendicularian species found showed a strong eurythermy and euryhalinity. Oligothermic and endemic elements were absent. None of the abundant species found was restricted to a single water mass. A total of 19 species was found in the present survey. Eleven species were referred to coastal waters, 16 to shelf and 13 to tropical ones. Ten species were found to be common to the three water masses. Oikopleura longicauda was the most frequent species occurring in nearly all the samples. Oikopleura dioica did not occur beyond the shelf. There was evidence of temperate zone populations, especially of coastal species. The region of Florianópolis was found to be the reproduction zone for some species. Species number decreases coastalwards and showed great fluctuations in tropical and shelf waters. Environmental preferences for different genera were dubious although fritillarids were more sensitive to dilution. There was evidence of stratified distribution which suggests the presence of different ecological spaces in the same water mass. Different groups of species were present within water masses having the same properties of salinity and temperature whereas physically different water masses showed equivalent groups. Eight different groups of species were found to be exclusive of coastal waters, 19 groups exclusive of tropical and 5 groups exclusive of shelf waters. Seven groups occurred in two or three different water masses. Certain species showed a degree of morphological plasticity. Data suggest that for some species individuals reproduce more than once before death. Otherwise, a high degree of decaying processes accompanying reproduction were found. Fritillaria pellucida and $F$. borealis have a protandrous maturity but $F$. haplostoma is a protogynous hermaphrodite. Ghost specimens, isolated tails and digestive knots occurred in the samples. Epiparasites were present on the tails of $O$. longicauda from mixed waters. There were indications of predation by medusae, acoels, copepods, ostracods, chaetognaths and mature animals served especially as food. A diurnal rhythm in the abundance of specimens at the surface was noticed.

\section{RES UMO}

Os tipos de distribuição dos organismos do plâncton são resultado de uma complexa interação de fatôres bióticos e abióticos. A distribuição diferencial das espécies de apendiculárias foi analisada em relação aos fatôres do ambiente, temperatura e salinidade. Os resultados sugerem que as propriedades físicas analisadas são menos importantes para explicar as distribuições observadas do que o conhecimento da história e dinâmica biológica 
das massas de água. A área estudada, estendendo-se de Cabo Frio ao Rio Grande do Sul, representa uma zona de transição caracterizada por processos de mistura e instabilidade com altos gradientes, especialmente de temperatura e salinidade. Ocorreram apenas massas de água modificadas ou misturadas com perdas de suas características iniciais e reflexos em seus esteno-elementos. A maioria das espécies de apendiculária mostrou forte euritermia e eurihalinidade. Elementos oligotérmicos e endêmicos estiveram ausentes. Nenhuma das espécies abundantes restringiu-se a apenas uma massa de água. Um total de 19 espécies foi encontrado no presente estudo. Onze espécies foram encontradas nas águas costeiras, 16 nas de plataforma e 13 nas águas tropicais. Dez espécies foram comuns aos três tipos de água. Oikopleura longicauda foi a espécie mais freqüente, ocorrendo em quase tôdas as amostras. Oikopleura dioica restringiu-se à plataforma. Houve evidência de populações exclusivas de zona temperada, especialmente em espécies costeiras. A região de Florianópolis revelou ser centro reprodutivo para algumas espécies. O número de espécies decresceu em direção à costa e flutuou consideràvelmente nas águas tropical e de plataforma. A preferência do ambiente para os diferentes gêneros foi dúbia. Fritillarias foram mais sensíveis à diluição. Houve evidência de distribuição estratificada e sugere-se a presença de diferentes espaços ecológicos numa mesma massa de água. Grupos diversos de espécies estiveram presentes em massas de água com as mesmas propriedades de temperatura e salinidade e massas de água fisicamente diferentes apresentaram grupos iguais. Oito diferentes grupos de espécies foram exclusivos das águas costeiras, 19 exclusivos das águas tropicais e 5 de águas de plataforma. Sete grupos ocorreram em mais de uma massa de água. Certas espécies mostraram plasticidade morfológica. Os dados sugerem que indivíduos de certas espécies reproduzem-se mais de uma vez antes da morte. Foi evidenciado um alto grau de processos degenerativos associados à reprodução. Fritillaria pellucida e $\vec{F}$. borealis são protândricos e $F$. haplostoma é hermafrodita protogínico. Ocorreram fantasmas, caudas livres bem como nó digestivo isolado. Epiparasitas estiveram presentes na cauda de $O$. longicauda procedente de águas misturadas. Medusas, acela, copépodos, ostrácoda, quetognata predam as apendiculárias e especialmente animais maduros servem de alimento. Foi observado um ritmo diurno em abundância de espécimes na superfície.

\section{ACKNOWLEDGEMENTS}

Thanks are due to Dr. F. J. Vernberg (Duke University) and to Dr. Marta Vannucci for reading the manuscript critically.

\section{B I B L I O G R A P H Y}

Almeida Prado, M. S. DE

1961. Distribuição dos Chaetognatha no Atlântico Sul Ocidental. Bolm Inst. oceanogr. S Paulo, v. 11 (4), p. 15-49.

Alvariño, A.

1964. Bathymetric distribution of chaetognaths. Pacif. Sci. v. 17 (1), p. 64-82.

BANSE, K.

1955. Uber das Verhalten von meroplanktischen Larven in geschichtetem Wasser. Kieler Meeresforsch. v. 11 (2), p. 188-200.

BARY, B. M.

1960. Notes on ecology, distribution and systematics of pelagic Tunicata. Pacif. Sci. v. 14 (2), p. 101-121. 
BARY, B. MCK.

1963. Temperature, salinity and plankton in the Eastern North Atlantic and coastal waters of Britain, 1957. III - The distribution of zooplankton in relation to water bodies. J. Fish. Res. Bd Can. v. 20 (6), p. 1519-1532.

BeKLemishev, K. V.

1957. The spatial interrelationships of marine zoo and phytoplankton. In: Nikitin, B. N., ed. Marine Biology, p. 206-226. Washington, D.C., Amer. Inst. Biol. Sci.

BERNARD, M.

1958. Systématique et distribution saisonnière des Tuniciers pélagiques d'Alger. Rapp. Procès-Verb. Réun. Comm. Intern. Expl. Sci. Médit. v. 14 n.s., p. 211-231.

Bigelow, H. B.

1926. Plankton of the offshore waters of the Gulf of Maine. Bull. Bur. Fish. 40 (2) (1924), p. 1-509.

BJÖRNBERG, T. K. S.

1963. On the marine free-living copepods off Brazil. Bolm Inst. oceanogr. S Paulo, v. 13 (1), p. 3-142.

BJÖRNBERG, T. K. S. \& ForNERIS, L.

1955. Resultados científicos do cruzeiro do 'Baependí e do 'Vega' à Ilha da Trindade. Copelata. Contrções Inst. oceanogr. Univ. S. Paulo, Ocean. Biol. n. ${ }^{\circ}$ 1, p. 1-68.

1956a. On the uneven distribution of the Copelata of the Fernando de Noronha area. Bolm Inst. oceanogr. S Paulo, v. 7 (1-2), p. 105-111.

1956b. On the uneven distribution of the Copelata of the Alcatrazes area. Bolm Inst. oceanogr. S Paulo, v. 7 (1/2), p. 113-115.

1958. Resultados científicos de los cruceros del 'Baependi' y del 'Vega' a la Isla Trindade. Copelata 2. Neotropica v. 4 (15), p. $81-85$.

BǗckmann, A.

1924. Bemerkung über Appendicularien der Ausbeute der Deutschen Südpolar-Expedition. Zool. Anz. v. 59, p. 205.

DAVID, P. M.

1961. The influence of vertical migration on speciation in the oceanic plankton. System. Zool. v. 10 (1), p. 10-16.

EMILSSON, I.

1956. Relatório e resultados físico-químicos de três cruzeiros oceanográficos em 1956. Contrçōes Inst. oceanogr. Univ. S. Paulo, Ocean. Física n..$^{\circ}$, p. 1-70.

1959. Alguns aspectos físicos e químicos das águas marinhas brasisileiras. Ciênc. Cult., S Paulo v. 11 (2), p. 44-54.

1960. Factores ambientales determinantes de las migraciones: factores cinemáticos. UNESCO, Symposium sobre migraciones de organismos mariños, Guayaquil. 8 p. (Mimeographed copy). 
EMILSSON, I.

1961. The shelf and coastal waters off Southern Brazil. Bolm Inst. oceanogr. S Paulo v. 11 (2), p. 101-102.

ESSENBERG, C. E.

1922. The seasonal distribution of the Appendicularia in the region of San Diego, California. Ecology, v. 3, p. 54-64.

1926a. Copelata from the San Diego Region. Univ. Calif. Publ, Zool. v. $28(22)$, p. $399-521$.

1926b. Observations on gradual disintegration and death of Copelata. Univ. Calif. Publ. Zool. v. 28 (23), p. 523-525.

FAGER, E. W. \& Mc Gowan, J. A.

1963. Zooplankton species groups in the North Pacific. Science v. 140 (3566), p. 453-460.

Fenaux, R.

1959. Observations écologiques sur les appendiculaires du plancton de surface dans la baie de Villefranche-sur-Mer. Bull. Inst. océanogr. Monaco n. ${ }^{\circ} 1141$, p. 1-26.

1961. Existence d'un ordre cyclique d'abondance relative maximale chez les Appendiculaires de surface (Tuniciers pélagiques). C. R. Hebd. Séanc. Acad. Sci. v. 253, p. 2271-2273.

1963a. Ecologie et biologie des Appendiculaires méditerranéens (Villefranche-sur-Mer). Vie et Milieu Suppl. n. ${ }^{0}$ 16, p. 1-142.

1963b. Composition annuelle de la population de Oikopleura longicauda (Appendiculaire). Rapp. Procès-Verb. Réun. Comm. Intern. Expl. Sci. Médit. v. 17 (2), p. 635-636.

FoL, H.

1872. Etude sur les Appendiculaires du Détroit de Messine. Mém. Soc. Phys. Hist. nat. Genève v. 21 (2), p. 445-449.

ForNeris, L.

1957. The geographical distribution of the Copelata. Anais Acad. bras. Ciênc. v. 29 (2), p. 273-284.

Fraser, J. H.

1937. The distribution of Chaetognatha in Scottish waters during 1936, with notes on the Scottish indicator species. J. Conseil v. 12 (3), p. $311-320$.

1939. Chaetognaths in Scottish waters. J. Conseil v. 14 (1), p. 25-34.

1952. The Chaetognatha and other zooplankton of the Scottish area and their value as biological indicators of hydrographical conditions. Scottish Home Dept. Mar. Res. n. ${ }^{\circ}$ 2, p. 5-52.

1955. The plankton of the waters approaching the British Isles in 1953. Scottish Home Dept. Mar. Res. n. ${ }^{\circ}$, p. 3-12. 
Fraser, J. H.

1961. The oceanic and batypelagic plankton of the Northeast Atlantic and its possible significance to fisheries. Dept. Agric. Fish. Scotl. Mar. Res. n. ${ }^{\circ} 4,48$ p.

Friedrich, H.

1955. Materialien zur Frage der Artbildung in der Fauna des marinen Pelagials. Veröfft. Inst. Meeresf. Bremerhaven v. 3 (2), p. 159-189.

GARNeR, D. M.

1959. The subtropical convergence in New Zealand waters. N. Z. J1

Geol. Geophys. v. 2 (2), p. 315-337.

HARDY, A. C.

1936. Observations on the uneven distribution of oceanic plankton.

'Discovery' Rep. v. 11, p. 511-538.

Hardy, A. C. \& Gunther, E. R.

1935. The plankton of the South Georgia whaling grounds and adjacent waters, 1926-1927. 'Discovery' Rep. v. 11, p. 1-356.

Hedgreth, J. W.

1957. Classification of marine environments. In: Hedgpeth, J. W., ed. - Treatise on marine ecology and paleo-ecology v. 1, p. 1727. (Geol. Soc, Amer. Mem. 67).

HENSEN, V.

1911. Das Leben im Ozean nach Zählungen seiner Bewohner. Resultate der quantitative Untersuchungen. Egebn. Atlant. Ozean Plankton-exped. Humboldt-Stift. v. 50, 406 p.

HeNTSChel, E.

1933. Allgemeine Biologie des Südatlantischen Ozeans. 1. Das Pelagial der obersten Wasserschicht. Wiss. Ergbn. Deutsch. Atlant. Exped. 'Meteor' (1925-1927) v. 11 (1), p. 1-168.

Hentschel, E. \& WatTenberg, H.

1930. Plankton und Phosphat in der Oberflächenschicht des Südatlantischen Ozeans. Arm. d. Hydrogr. v. 58, p. 273-277.

Hesse, R., Allee, W. C. \& Schmidt, K. P.

1951. Ecological animal geography. New York, John Wiley, xiii+ 715 p.

KINNE, O.

1957. A programmatic study of comparative biology of marine and brackish water animals. In: Colloque internat. biol. mar., Roscoff 1956. Année biol. v. 33 (1/2), p. 87-92.

LOHMANN, H.

1896. Die Appendicularien der Plankton-Expedition. Ergebn. Atlant. Ozean. Plankton-exped. Humboldt-Stift. v. 2 E c., p. 1-148.

1905. Die Appendicularien des arktischen und antarktischen Gebiets, ihre Beziehungen zueinander und zu den Arten des Gebiets der warmen Ströme. Zool. Jahrb., Suppl. 8, p. 353-382. 
LOHMANN, H.

1909. Copelata und Thaliacea. In Michaelsen - Die Fauna Südwest-Australiens v. 2 (10), p. 143-149.

1928. Die Appendicularien-Bevölkerung der Weddellsee. Beiträge zur Planktonbevolkerung der Weddellsee nach den Ergebnissen der Deutschen Antarktischen Exped. 1911-12. Beiträge 2 Intern. Rev. gesamt. Hydrobiol. u. Hydrogr. v. 20 (1/2), p. 13-72.

1931. Die Appendicularien der Deutschen Tiefsee-Expedition. Wiss. Ergeb. 'Valdivia', $1898-99$ v. 21 (1), p. 1-158.

1933/34. Appendicularia. In Kükenthal \& Krumbach Handb. d. Zool. v. $5(2)$, p. 1-202.

LohmanN, H. \& BÜckmanN, A.

1926. Die Appendicularien der Deutschen Süd-polar Expedition-190103. Dt. Südpol.-Exped. (1903-1905) v. 18 (Zool. 10) p. 63-231.

LohmanN, H. \& Hentschel, E.

1939. Die Appendicularien im Südatlantischen Ozean. Wiss. Ergeb. Deutsch. Atlant. Exped. 'Meteor' (1925-27) v. 13 (3), p. 153243.

Mc Gowan, J. A.

1960. The relationship of the distribution of the planktonic worm, Poebius meseres Heath, to the water masses of the North Pacific. Deep Sea Res. v. 6 (2), p. 125-139.

MoORE, H. B.

1952. Physical factors affecting the distribution of euphausids in the North Atlantic. Bull. mar. Sci. Gulf Caribb. v. 1 (4), p. 278305 .

MOORE, H. B. \& O'BerRy, D. L.

1957. Plankton of the Florida Current. IV. Factors influencing the vertical distribution of some common copepods. Bull. mar. Sci. Gulf Caribb. v. 7 (4), p. 297-311.

MoRrison Cassie, R.

1957. The sampling problem with particular reference to marine organisms. Proc. N. Z. ecol. Soc. n. ${ }^{\circ} 4$, p. 37-39.

1959a. Microdistribution of plankton. N. Z. J1 Sci. v. 2 (3), p. 398409.

1959b. An experimental study of factors inducing aggregations in marine plankton. N. Z. Jl Sci. v. 2 (3), p. 339-365.

1960. Factors influencing the distribution pattern of plankton in the mixing zone between oceanic and harbour waters. N. Z. J1 Sci. v. 3 (1), p. $26-50$.

OKuDA, T.

1962. Physical and chemical oceanography over continental shelf between Cabo Frio and Vitória (Central Brazil). J. ocean Soc. Japan, 20th Anniversary v., p. 514-540. 
RADOVICH, J.

1952. Food of the Pacific sardine, Sardinops caerulea from central Baja California and Southern California. Calif. Fish Game v. 38 (4), p. $575-585$.

RusSell, F. S.

1935. Review of some aspects of zooplankton research. Rapp. Procès-Verb. Réun. C.P.I.E.M. v. 45, p. 5-30.

Russell, F. S. \& Colmam, J. S.

1935. The zooplankton. IV. The occurrence and seasonal distribution of the Tunicata, Mollusca and Coelenterata. Great Barrier Reef Exped. 1928-29, Sci. Res. v. 2 (7), p. 219-231.

Shelbourne, J. E.

1953. The feeding habits of the plaice post-larvae in the Southern Bight. J. mar. biol. Ass. U.K. v. 32 (1), p. 149-160.

1962. A predator-prey size relationship for plaice larvae feeding on Oikopleura. J. mar. biol. Ass. U.K. v. 42, p. 243-252.

Srmmons, E. G.

1957. An ecological survey of the upper Laguna Madre of Texas. Publs Inst. mar. Sci. Univ. Texas v. 4 (2), p. 156-200.

SteEmanN-Nielsen, E.

1954. On organic production in the oceans. J. Conseil v. 19 (3), p. 309-328.

Strickland, J.'D. H.

1963. Summation. Components of ecosystems. In Marine Biology I. Proc. of the First Intern. Interdisc. Conference (1961), p. 9286. Ed. G. A. Riley.

Sverdrup, H. U. \& Allen, W. E.

1939. Distribution of diatoms in relation to the character of water masses and currents off Southern California in 1938. J. mar. Res. v. 2 (2), p. 131-144.

Sverdrup, H., Johnson, M. W. \& Fleming, R. H.

1954. The oceans. New York, Prentice-Hall, $\mathrm{x}+1087 \mathrm{p}$.

Thompson, H. T.

1948. Pelagic tunicates of Australia. Comm. Council Sci. \& Indust. Research Australia, 196 p.

TokiokA, T.

1940. Some additional notes on the Japanese appendicularian fauna. Rec. Ocean. Works Japan v. 11 (1), p. 1-26.

1950. Droplets from the plankton net. VI. Notes on the posterior protuberances found in some fritillarians. Publs Seto mar. biol. Lab. v. 1 (3), p. 153-155.

1951. Pelagic tunicates and chaetognaths collected during the cruises to the New Yamato Bank in the Sea of Japan. Publs Seto mar. biol. Lab. v. 2 (1), p. 1-25. 
TokiokA, T.

1955. General consideration on Japanese appendicularian fauna. Publs Seto mar. biol. Lab. v. 4 (2-3), p. 251-261.

1956. Fritillaria arafoera n. sp. a form of the sibling species: Fritillaria haplostoma - complex (Appendicularia: Chordata). Pacif. Sci. v. 10 (4), p. 403-406.

1960. Studies on the distribution of appendicularians and some thaliaceans of the North Pacific, with some morphological notes. Publs Seto mar. biol. Lab., v. 8 (2), p. 351-443.

TONOLLI, V. \& L.

1958. Irregularities of distribution of plankton communities: considerations and methods. In Buzzati-Traverso, A. A., ed. Perspectives in marine biology, p. 137-143. Berkeley, Univ. Calif Press.

UDVARDY, M. D. F.

1954. Distribution of appendicularians in relation to the Strait of Belle Isle. J. Fish. Res. Bd Can. v. 11 (4), p. 431-453.

1958. Appendicularia. Further zool. Results Swed. Antarct. Exped. 1901-03, v. 5 (1), p. 2-15.

VANNUCCI, M.

1957. A nova sistemática e a planctonologia. Bolm Inst. oceanogr. v. $8(1-2)$ p. $217-223$.

1962. Preliminary results on the study of the zooplankton standing stock off the South Brazilian Coast at $25^{\circ}$ lat. S. Contrçōes Inst. oceanogr. Univ. S Paulo, Ocean. Biol. n. ${ }^{\circ}$ 3, p. 1-28.

1963. On the ecology of Brazilian medusae at $25^{\circ}$ lat. S. Bolm Inst. oceanogr. v. 13 (1), p. 143-184.

VERNIERES, $P$.

1933. Essai sur l'histoire des Appendiculaires de Banyuls et de Sète. Bull. Inst. oceanogr. Monaco n. ${ }^{\circ} 617$, p. 1-60.

VINOGRADOV, M. \& Voronina, N.

1962. The distribution of different groups of plankton in accordance with their trophic level in the Indian Equatorial current area. Rapp. Procès-Verb. Réun. C.P.I.E.M. v. 153, p. 200-204.

YounT, J. L.

1958. Distribution and ecological aspects of Central Pacific Salpidae (Tunicata). Pacif. Sci. v. 12 (2), p. 111-130.

Willey, A.

1915. The plankton of St. Andrew's Bay. Contr. Can. Biol. v. 1, Mar. Biol. Sessional Paper n. ${ }^{\circ} 39 b$, p. 1-9. 


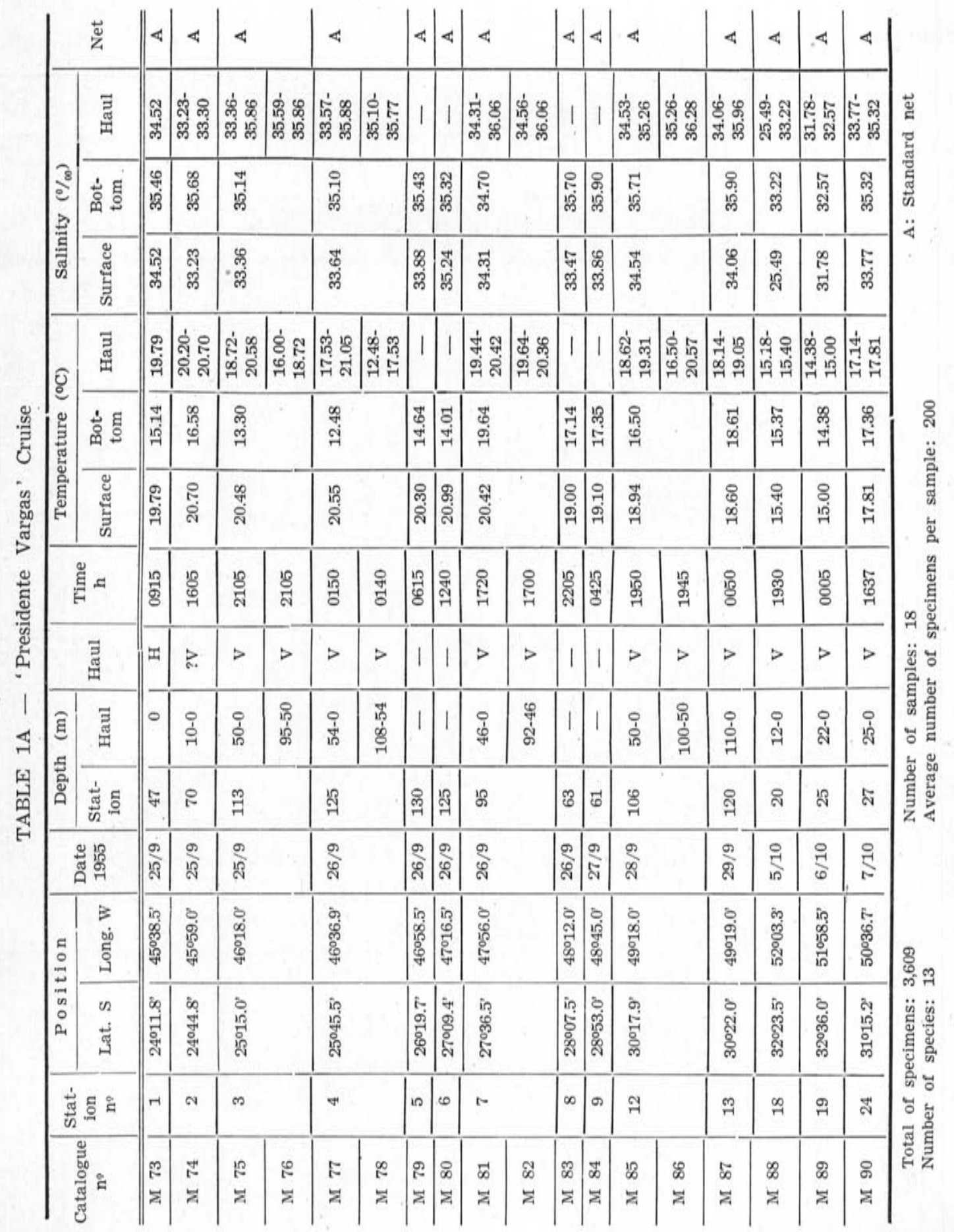




\begin{tabular}{|c|c|c|c|c|c|c|c|c|c|}
\hline & I & $\infty$ & \&ै & ฉึ & ล & ஜ्: & $\mathscr{R}$ & $\infty$ & \& \\
\hline & sIIBLL & 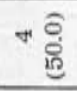 & ลㅇํㄹ & จㄹ & 유 & भ & สิ & 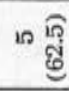 & on \\
\hline \multirow{5}{*}{ 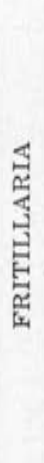 } & ds & 1 & ㄱำ & r & क न & 10 $\frac{\hat{\sigma}}{\mathscr{e}}$ & in & 1 & m \\
\hline & epıวnাəd & 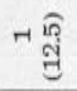 & 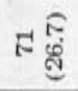 & 욤ำ & 1 & 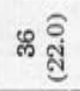 & ผั สู & 1 & 1 \\
\hline & вшоһรоโdвч & 1 & $\nabla \stackrel{\text { क़ी }}{\mathrm{C}}$ & म ब & N & 율 & 1 & - & 1 \\
\hline & вогuxов & 1 & क & 오ำ & 1 & rढ़ & N & 1 & 1 \\
\hline & s|rвอ.oq & 1 & 1 & न ฒุ & 1 & m & 1 & 1 & m $\frac{\vec{y}}{9}$ \\
\hline & $\begin{array}{r}\text { unusвu } \\
\text { вuоsoรวเS }\end{array}$ & 1 & 1 & 1 & 1 & 1 & 1 & I & ผ ซิ \\
\hline \multirow{9}{*}{ 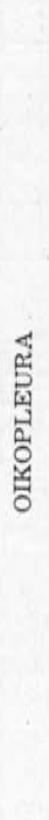 } & 'ds & 1 & 绝 & ஓ & 유윰 & ำ ฮู่ & ־ สู & 1 & m \\
\hline & suəosəzn. & 1 & 1 & I & 1 & ผ สุ & ๙ & 1 & $\rightarrow$ ลิ \\
\hline & врпвวรินันо & N $\frac{\hat{D}}{\mathfrak{d}}$ & $E$ E & है กู & ๙ & 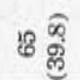 & ๓ & N & ลี \\
\hline & вІрәшихәчи & 1 & ฟี่ & ने है & 1 & トสู & 1 & 1 & 1 \\
\hline & รแโวะ. & 1 & 1 & I & 1 & I & r क़్ర & 1 & 1 \\
\hline & słux.xoมsn & .1 & N E⿱丷⿹ & 1 & 1 & $\omega \stackrel{\hat{\oplus}}{\oplus}$ & 1 & 1 & 1 \\
\hline & врџорір & तु & $\rightarrow$ ભ్ है & $-\mathrm{m}$ & 1 & 1 & 1 & 1 & 1 \\
\hline & вว.әวочđоว & 1 & 1 & 1 & 1 & 1 & 1 & 1 & 1 \\
\hline & suвэтів & 1 & 1 & 1 & 1 & 1 & 1 & 1 & 1 \\
\hline & ๑4 บоำ? & $H$ & N & $m$ & & 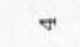 & & in & $\omega$ \\
\hline & 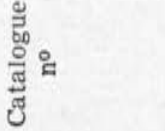 & $\begin{array}{l}\text { ஜ } \\
\Rightarrow\end{array}$ & $\begin{array}{l}5 \\
z\end{array}$ & $\begin{array}{l}\text { is } \\
2\end{array}$ & $\begin{array}{l}\stackrel{0}{2} \\
\dot{z}\end{array}$ & $\begin{array}{l}F \\
z\end{array}$ & $\begin{array}{l}\infty \\
\stackrel{0}{2} \\
z\end{array}$ & $\begin{array}{l}\text { \% } \\
=\end{array}$ & $\begin{array}{l}\text { \& } \\
=\end{array}$ \\
\hline
\end{tabular}




\begin{tabular}{|c|c|c|c|c|c|c|c|c|c|}
\hline 嵒 & $\underset{H}{\mathscr{R}}$ & 量 & 菏 & ஜू & 옴 & 吕 & $\mathbb{T}$ & 5 & 7 \\
\hline ద을 & 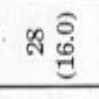 & ๗઼્్ુ & 1 & 迥 & m心 & 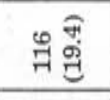 & ๙ ָิ & F默 & ๙ \\
\hline 的 & ल & 1 & 1 & 1 & 1 & 1 & 1 & 1 & 1 \\
\hline 1 & ๙ $\widehat{\mathcal{E}}$ & ร & 7 ब్ & નึ สู่ & $r \stackrel{\varrho}{\mathrm{C}}$ & $+\stackrel{\varrho}{\varrho}$ & 1 & 1 & 1 \\
\hline H & 1 & 1 & m $\stackrel{\hat{d}}{\mathrm{C}}$ & ๓ & 1 & N & 1 & 1 & 1 \\
\hline 1 & DF & - & 1 & 1 & 1 & 1 & 1 & 1 & 1 \\
\hline H炅 & 1 & 1 & 1 & 1 & 1 & 1 & 1 & 1 & 1 \\
\hline NE્ & 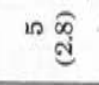 & 1 & 1 & 1 & 1 & 댕 & 1 & 1 & 1 \\
\hline 舛焉 & घ) & 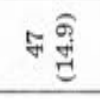 & i⿱ & 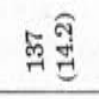 & 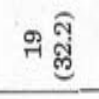 & ఐ & 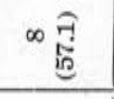 & $F \widehat{\overparen{e}}$ & ๙ \\
\hline ¡ శ్ల్ల & 유 $\underset{\text { 官 }}{\hat{0}}$ & N & $\exists \widehat{\sigma}$ & न नी & rढ़ & N & 1. & 1 & H \\
\hline ฉి & \&̊ & 式䈷 & 㞼 & ஜु & N & 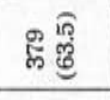 & ๙ तु & 1 & 1 \\
\hline 1 & 1 & 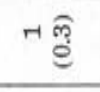 & 1 & 1 & 1 & অ & 1 & 1 & H \\
\hline 1 & 1 & 1 & 1 & 1 & 1 & 1 & 1 & 1 & 1 \\
\hline \& & 路 & ॠ สิ & N & 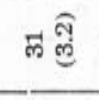 & 1 & N & 1 & 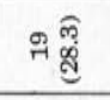 & $r \stackrel{\widehat{O}}{\dot{\theta}}$ \\
\hline H & 1 & मสู & 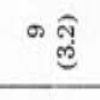 & of $\frac{\widehat{P}}{\text { id }}$ & ๙ & 1 & N ָู & 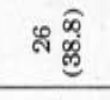 & * \\
\hline त & in $\underset{\widehat{~}}{\widehat{~}}$ & 1 & 1 & 1 & 1 & 1 & 1 & 1 & 1 \\
\hline 1 & 1 & 1 & 1 & 1 & 1 & m & 1 & 1 & 1 \\
\hline \multicolumn{2}{|l|}{ r } & $\infty$ & 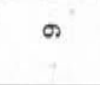 & \multicolumn{2}{|l|}{ ี } & $\stackrel{m}{\sim}$ & $\stackrel{\infty}{\sim}$ & $\stackrel{9}{7}$ & הี \\
\hline $\begin{array}{l}\vec{\infty} \\
\vec{z}\end{array}$ & $\begin{array}{l}\mathscr{\infty} \\
\Sigma\end{array}$ & $\begin{array}{l}\mathscr{\infty} \\
\bar{z}\end{array}$ & $\begin{array}{l}\vec{\infty} \\
\bar{z}\end{array}$ & $\begin{array}{l}\not \\
\Sigma\end{array}$ & $\begin{array}{l}\mathscr{D} \\
\Sigma\end{array}$ & $\begin{array}{l}\bar{\infty} \\
\bar{z}\end{array}$ & $\begin{array}{l}\infty \\
\infty \\
\bar{\alpha}\end{array}$ & $\begin{array}{l}\infty \\
\bar{Z}\end{array}$ & $\begin{array}{l}\stackrel{8}{ } \\
\ddot{\alpha}\end{array}$ \\
\hline & & & & & & & & & \\
\hline
\end{tabular}




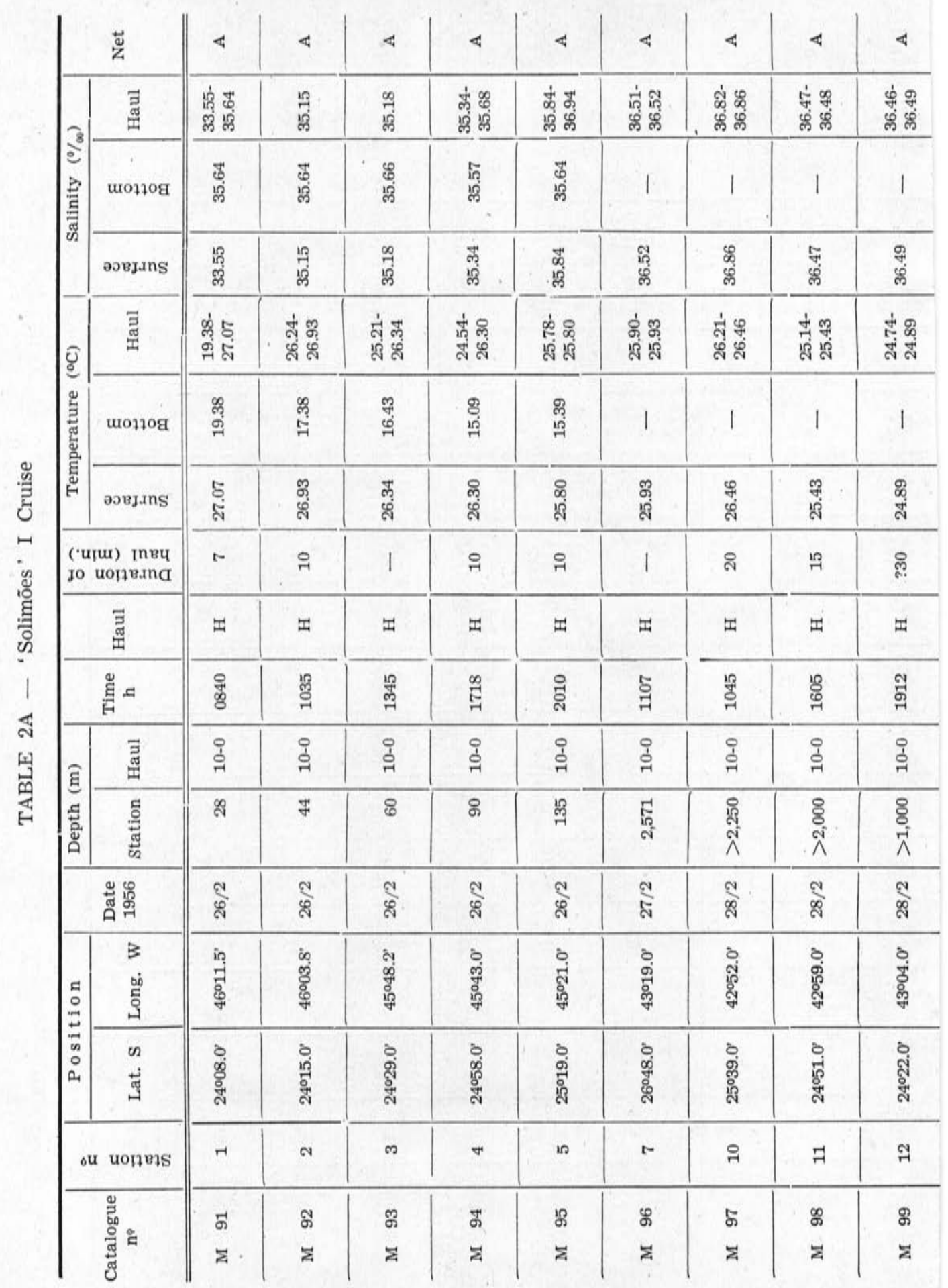




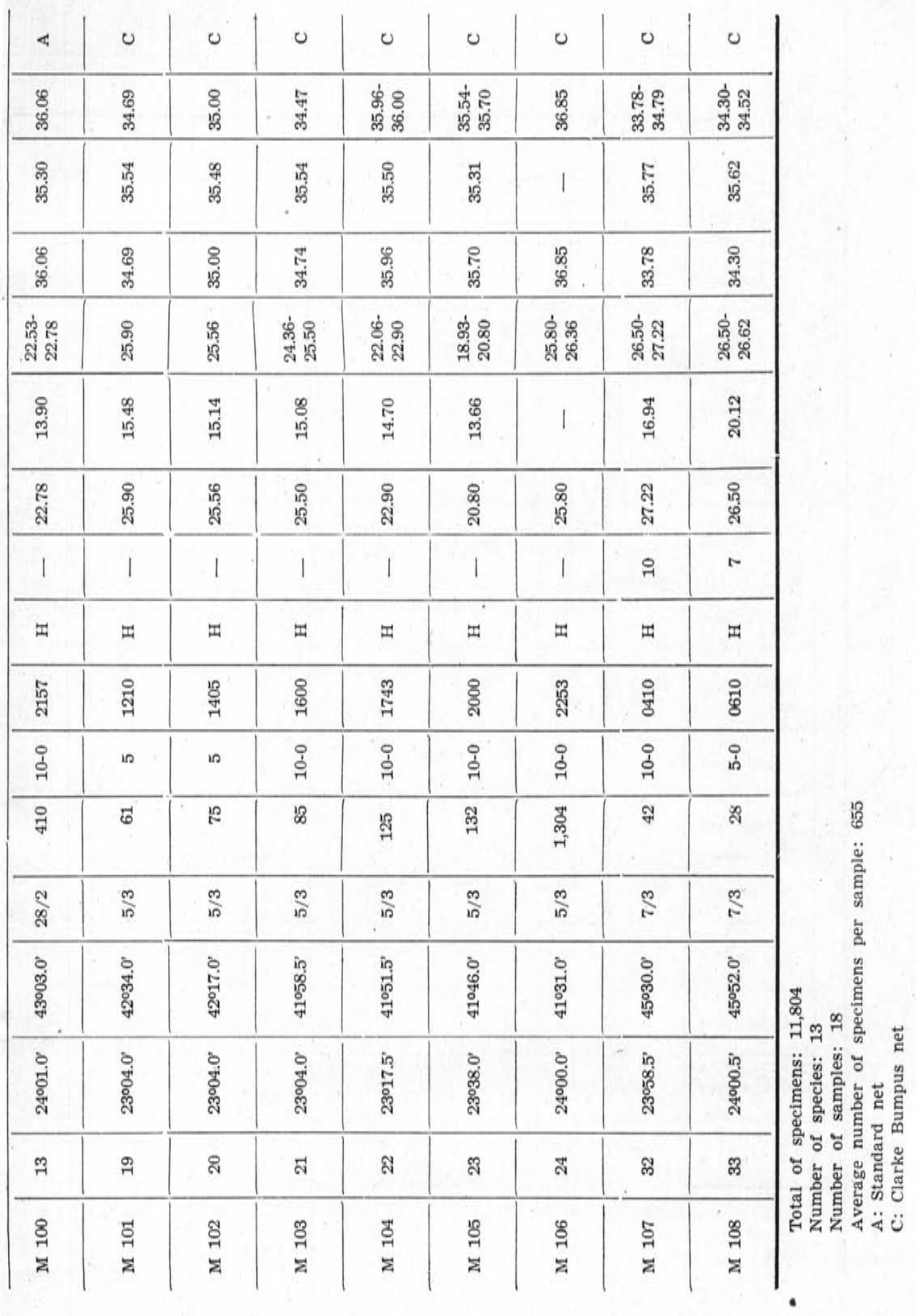




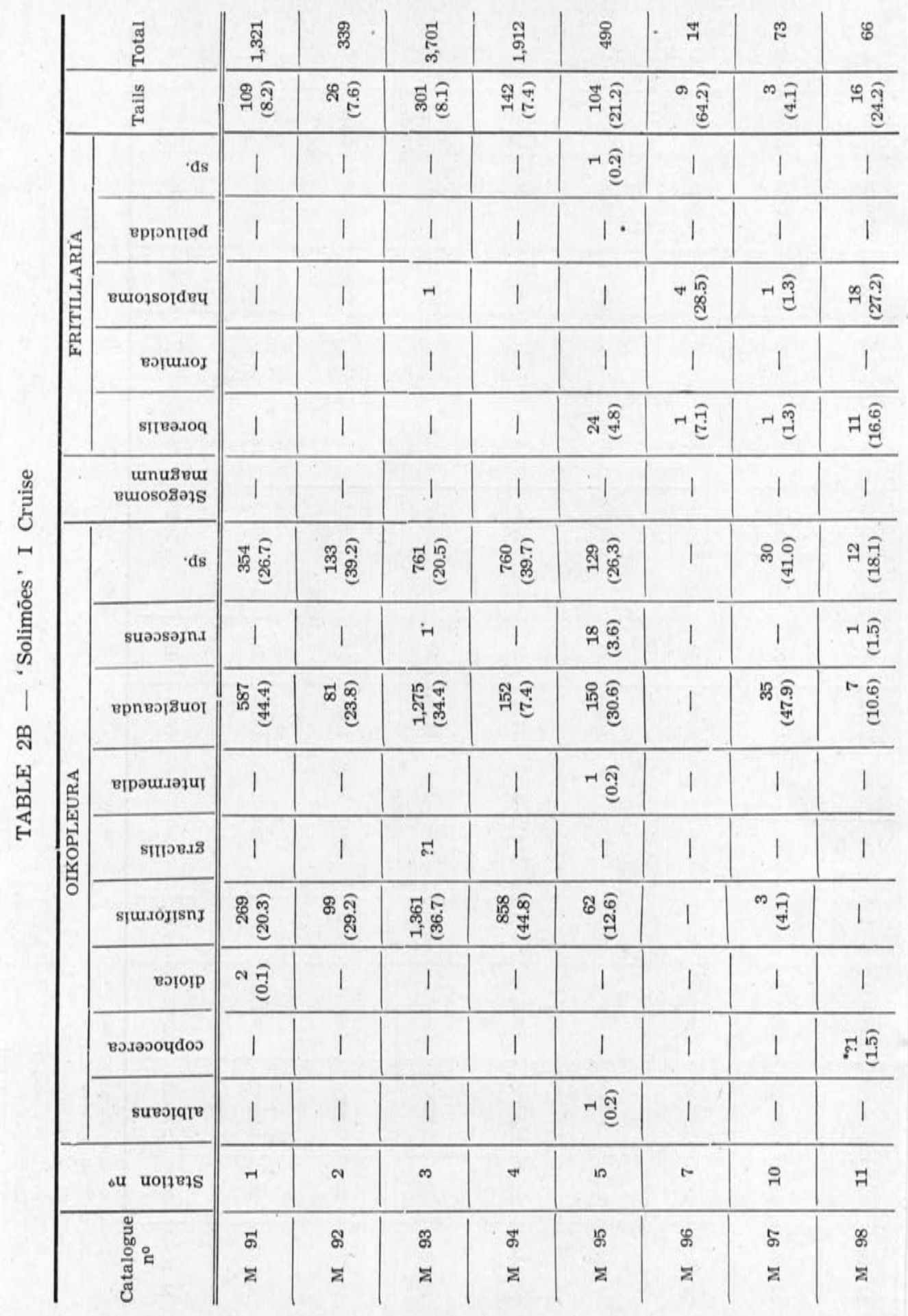




\begin{tabular}{|c|c|c|c|c|c|c|c|c|c|}
\hline 옹 & वू & ผู & హ్ & รู & $\mathbb{J}$ & ' & in & 苫 & $\stackrel{\oplus}{7}$ \\
\hline స్త స్ํ శ్ & ฟึ๊ & 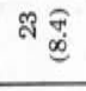 & 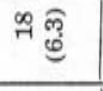 & क & เก & " & 1 & 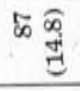 & लै \\
\hline 1 & ma & 1 & 1 & 1 & 1 & 1 & 1 & 1 & 1 \\
\hline 1 & N & 의 & .1 & 1 & 1 & 1 & 1 & 1 & 1 \\
\hline + & 융 & ๙ & 1 & in & 1 & 1 & 1 & n & • \\
\hline 1 & -1 & 1 & 1 & 1 & 1 & 1 & 1 & 1 & 1 \\
\hline m & ־ & 1 & 1 & 1 & 1 & 1 & 1 & 1 & 1 \\
\hline 1 & $\exists \stackrel{\infty}{\stackrel{\infty}{e}}$ & 1 & 1 & 1 & 1 & 1 & 1 & 1 & 1 \\
\hline 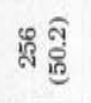 & 为点 & ซึ & ฟ艹 & ๑) ูู & मn & 1 & 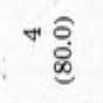 & 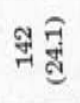 & ๙ู \\
\hline N कू & 둠 & 1 & 1 & 1 & 1 & 1 & 1 & เ & 1 \\
\hline $\begin{array}{l}\forall \\
\vec{~}\end{array}$ & 갈 & 哭 & ث્仓ิ & m & "ี้ సิ & 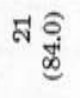 & rô. & 兽 & 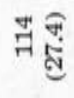 \\
\hline 1 & 1 & 1 & 1 & 1 & 1 & 1 & .1 & 1 & 1 \\
\hline 1 & 1 & 1 & 1 & 1 & 1 & 1 & 1 & 1 & 1 \\
\hline " & ฉี & प्रें & 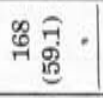 & 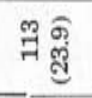 & 1 & 1 & 1 & 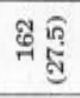 & 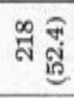 \\
\hline 1 & 1 & $\therefore \stackrel{\mathscr{c}}{\varrho}$ & 1 & 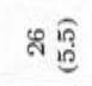 & 1 & 1 & 1 & 1 & 1 \\
\hline 1. & 1 & 1 & 1 & 1 & 1 & 1 & 1 & नન્ધ & 1 \\
\hline 1 & $\mathrm{H}$ & $\neg$ ஸุ & 1 & 1 & 1 & 1 & 1 & 1 & 1 \\
\hline ศี & $\stackrel{\dddot{7}}{-1}$ & $\stackrel{9}{\circ}$ & ิㅗ. & $\overrightarrow{\text { ה }}$ & สี & มี & $\ddot{~}$ & ศ్ & $\mathfrak{m}$ \\
\hline 8 & 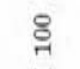 & Б્త & 억 & 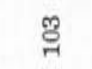 & $\underset{\sim}{\overparen{r}}$ & $\underset{7}{g}$ & $\stackrel{్}{\circ}$ & $\stackrel{్}{5}$ & 兽 \\
\hline $\bar{z}$ & $\bar{\Sigma}$ & $\Sigma$ & $\bar{z}$ & $\bar{z}$ & $z$ & $\Sigma$ & $\bar{z}$ & $\bar{\Sigma}$ & $\stackrel{\Sigma}{\alpha}$ \\
\hline
\end{tabular}




\begin{tabular}{|c|c|c|c|c|c|c|c|c|c|c|c|}
\hline \multicolumn{2}{|r|}{$\ddot{\check{z}}$} & 0 & 0 & 0 & 0 & 0 & 4 & 4 & 4 & \multicolumn{2}{|c|}{40} \\
\hline \multirow{3}{*}{ 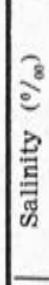 } & 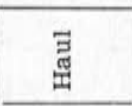 & $\underset{\infty}{\infty}$ & 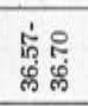 & 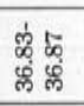 & 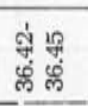 & 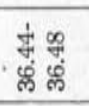 & 点 & 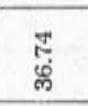 & 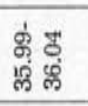 & 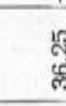 & 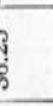 \\
\hline & шо교 & $\underset{c}{\infty}$ & 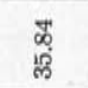 & 1 & 1 & 1 & 1 & 1 & 1 & Dे & 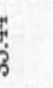 \\
\hline & วэยม.นnS & $\frac{\infty}{0}$ & : & 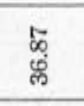 & 畒 & 悉 & 量 & 荧 & 菅 & $\begin{array}{ll}10 \\
0 \\
0 \\
0\end{array}$ & 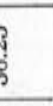 \\
\hline \multirow[b]{3}{*}{ 墕 } & 嵒 & 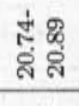 & สู่ & 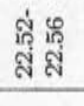 & $\begin{array}{l}\text { कुेक } \\
\text { नेส }\end{array}$ & 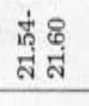 & 8 & สู & 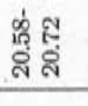 & 总 & 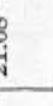 \\
\hline & шо구영 & 芯 & 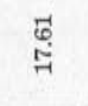 & 1 & 1 & 1 & 1 & 1 & 1 & ร & 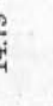 \\
\hline & әэвц..ns & జ़े & జึ. & 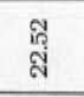 & సి & สं & ¿े & สู & 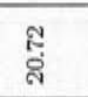 & $\begin{array}{l}0 \\
\text { ने }\end{array}$ & \\
\hline \multicolumn{2}{|c|}{$\begin{array}{l}\text { ('ulu) Inвu } \\
\text { Jo uopze.na }\end{array}$} & 1 & 1 & 1 & 1 & 1 & 1 & 1 & in & in & \\
\hline \multicolumn{2}{|c|}{ 草= } & 䍘 & ప్డి & \% & 용 & 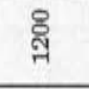 & 㐘 & 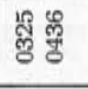 & 兽 & 思 & \\
\hline \multicolumn{2}{|r|}{ 褐 } & I & I & I & \# & ت & 푸 & I & F & I & \\
\hline \multirow{3}{*}{ 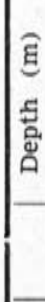 } & 镸 & ํํㅇ & ओे & †े & ओे & भे & "19. & 뭉 & 앙 & ชิ & ॠे \\
\hline & $\begin{array}{l}\text { 总 } \\
\text { 恖 }\end{array}$ & $\infty$ & 总 & $\begin{array}{l}8 \\
\text { ते } \\
\Lambda\end{array}$ & $\begin{array}{l}\stackrel{8}{8} \\
\text { N } \\
\wedge\end{array}$ & $\begin{array}{l}\text { \& } \\
\text { N } \\
\Lambda\end{array}$ & $\begin{array}{l}8 \\
\text { ¿ } \\
\Lambda\end{array}$ & 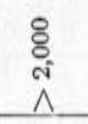 & $\begin{array}{l}8 \\
\text { ते } \\
\Lambda\end{array}$ & 원 & 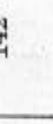 \\
\hline & 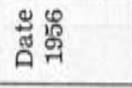 & $\stackrel{0}{=}$ & $\stackrel{0}{\sharp}$ & $\stackrel{8}{\sharp}$ & ڤ̊ & ڤִ & : & $\stackrel{\varphi}{\Phi}$ & $\stackrel{\varrho}{\leftrightarrows}$ & $\coprod_{\pi}$ & 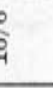 \\
\hline \multirow[b]{2}{*}{ 范 } & 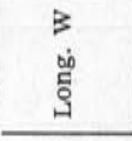 & $\begin{array}{l}\text { 它 } \\
\text { 量 }\end{array}$ & 逭 & 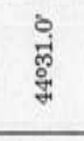 & 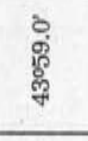 & ते & 蔃 & $\begin{array}{l}\text { 审 } \\
\text { 尊 }\end{array}$ & $\begin{array}{l}\text { 离 } \\
\text { 索 }\end{array}$ & สู่ & \\
\hline & 出 & 总 & $\begin{array}{l}\text { d. } \\
\text { d. } \\
\text { d. } \\
\text { and }\end{array}$ & 㻤 & $\begin{array}{l}\text { के } \\
\text { पे }\end{array}$ & 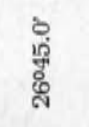 & 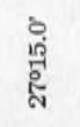 & 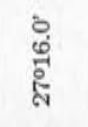 & 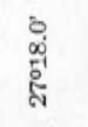 & 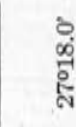 & 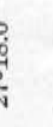 \\
\hline \multicolumn{2}{|c|}{ 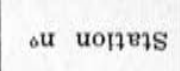 } & है & $\infty$ & ஜ̊ & 요 & 7 & $\%$ & 7 & $\$$ & 5 & $\frac{\pi}{4}$ \\
\hline \multicolumn{2}{|r|}{$\begin{array}{l}\text { :ू } \\
\text { oू ڤ } \\
\text { हुँ }\end{array}$} & $\begin{array}{l}\stackrel{8}{-1} \\
z\end{array}$ & $\begin{array}{l}\text { ‡े } \\
\text { च }\end{array}$ & $\begin{array}{l}\exists \\
z\end{array}$ & $\begin{array}{l}\frac{a}{7} \\
z\end{array}$ & $\stackrel{m}{7}$ & $\begin{array}{l}\vec{z} \\
z\end{array}$ & $\begin{array}{l}\stackrel{\text { g }}{7} \\
\ddot{z}\end{array}$ & 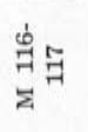 & $\begin{array}{l}\stackrel{\infty}{\sharp} \\
\sharp\end{array}$ & $\begin{array}{l}\frac{9}{7} \\
\vec{z}\end{array}$ \\
\hline
\end{tabular}




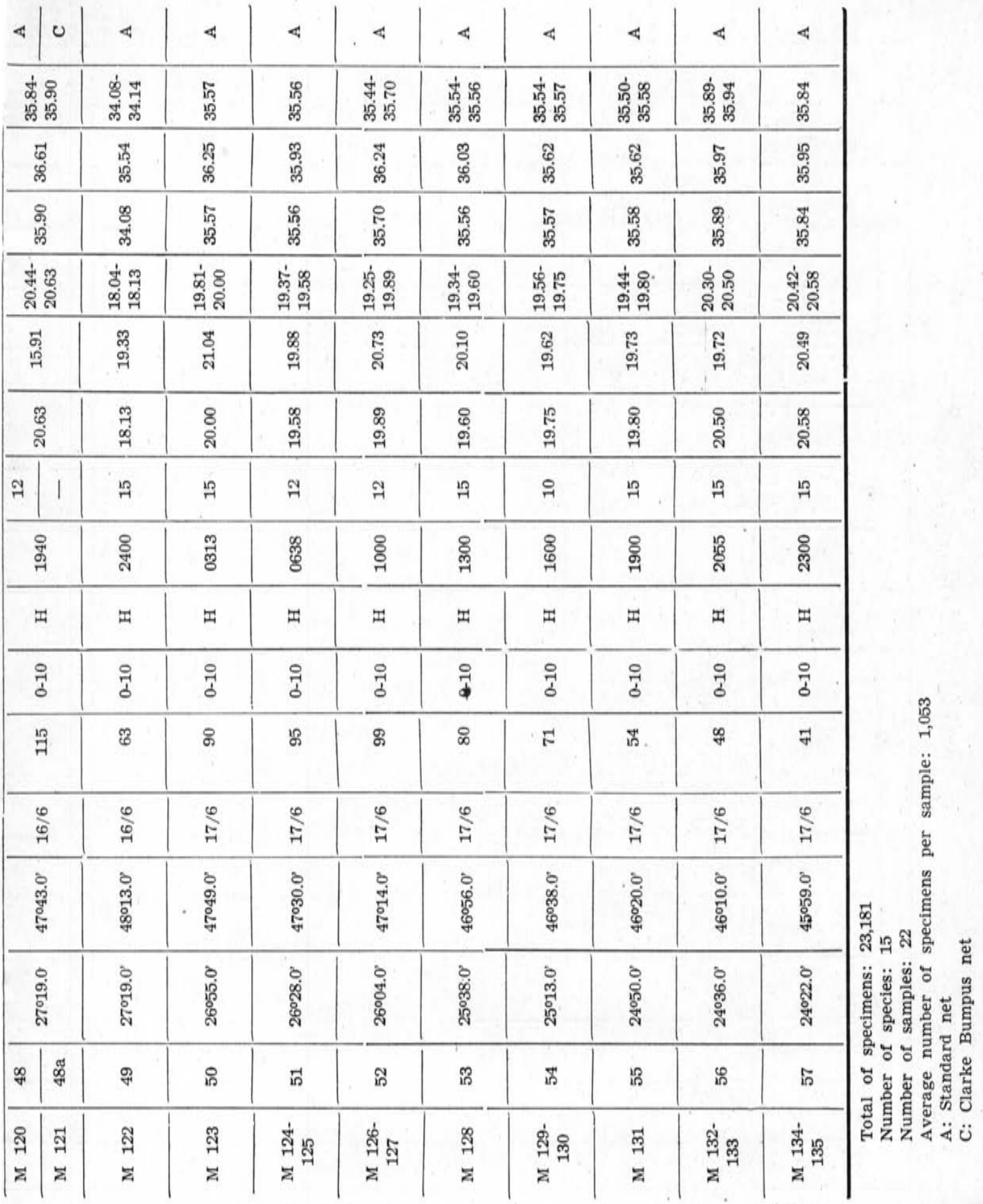




\begin{tabular}{|c|c|c|c|c|c|c|c|c|c|c|c|}
\hline & $\begin{array}{l}\text { ॠँ } \\
\text { ० } \\
\text { H }\end{array}$ & ס & สี & \& & $F$ & gి & శ్ & ลิ & कू & 年 & ลิ \\
\hline & 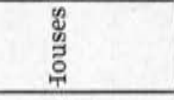 & 1 & 1 & 1 & 1 & I & 1 & 1 & " क्षे & कू & in \\
\hline & 呇 & ம) & $\infty \stackrel{\text { है }}{\text { लृ }}$ & 구 & 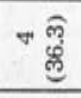 & 유 오ํ & $\infty$ ถึ. & 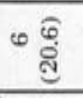 & 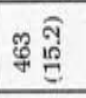 & 莺 & ถ \\
\hline & 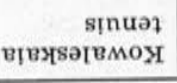 & 1 & 1 & 1 & 1 & 1 & 1 & 1 & 1 & 1 & 1 \\
\hline & 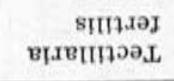 & 1 & 1 & 1 & 1 & 1 & 1 & 1 & 1 & 1 & 1 \\
\hline & ds & 1 & .1 & 1 & 1 & $\neg$ ลู่ & 1 & 1 & สี & ๙ नิ & 1 \\
\hline & 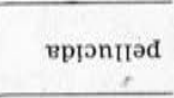 & ${ }^{\infty}$ สู่ & - స్ & N & Hôे & ผ & 1. & 1 & 萬 & $\stackrel{120}{\circ}$ & 1 \\
\hline 起 & вuัoวsoIdвน & * ิㅡㄹ & ન ึู & in $\stackrel{\hat{Q}}{\mathrm{E}}$ & 1 & I & 1 & 1 & ले & in & 1 \\
\hline 蒝 & รแюв.ภร & 1 & 1 & 1 & 1 & 1 & 1 & 1 & 1 & $-\bar{छ}$ & 1 \\
\hline & 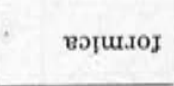 & 1 & 1 & 1 & 1 & 1 & न & 1 & ส & * สู & 1 \\
\hline & șтвә.оq & 1 & 1 & 1 & 1 & - तु & - ููํ & 1 & 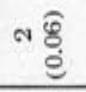 & ๓ ฐู่ & 1 \\
\hline & 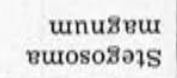 & I & 1 & 1 & 1 & 1 & 1 & $-\overrightarrow{\text { क्ष }}$ & * ने & * नें & 1 \\
\hline & ds & न & 10 है & ம & เ & $\stackrel{्}{\stackrel{0}{\vec{J}}}$ & $\infty$ ถิ่ & ন্ & ঃ ڤ્లి & 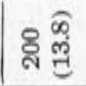 & 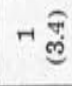 \\
\hline & suərnx & 1 & 1 & 1 & 1 & 1 & न ָู & 1 & ซึ่ สู & \& & 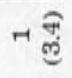 \\
\hline & врпвэรินоо & Hôे & ન炁 & " & Hอิ & 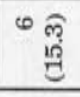 & 气命 & न तुํำ & 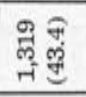 & 18 & 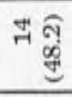 \\
\hline 䍃 & รцाกв.18 & 1 & 1 & 1 & 1 & 1 & 1 & 1 & 1 & 1 & 1 \\
\hline ํㅣㅁ & ș̣u.toมısnI & N $\widehat{\varrho}$ & 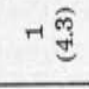 & 1 & 1 & $m \stackrel{Q}{E}$ & 1 & 1 & مै & ㅇำ & m \\
\hline & војогр & 1 & 1 & 1 & 1 & 1 & 1 & 1 & 1 & 1 & 1 \\
\hline & вәхәวочđог & 1 & 1 & 1 & 1 & 1 & - तु & 1 & 1 & I & 1 \\
\hline & suвojq18 & 1 & 1 & 1 & 1 & 1 & ल हิ & नें & 1 & ๓ ลู่ & 1 \\
\hline & 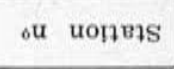 & 5 & 品 & 品 & 워 & F & $\mathscr{F}$ & 7 & $\mathscr{f}$ & ร & ูํำ \\
\hline & u คทรัоเвาะอ & $\begin{array}{l}8 \\
\stackrel{9}{2} \\
\end{array}$ & $\begin{array}{l}\text { 윽 } \\
\text { 를 }\end{array}$ & $\begin{array}{l}7 \\
\bar{z} \\
\overline{2}\end{array}$ & $\begin{array}{l}\text { มี } \\
\text { ปี }\end{array}$ & $\begin{array}{l}\stackrel{n}{7} \\
\vec{z}\end{array}$ & $\begin{array}{l}\frac{\pi}{7} \\
\bar{z}\end{array}$ & $\begin{array}{l}\frac{10}{7} \\
\vec{z}\end{array}$ & $\begin{array}{l}\stackrel{6}{7} \\
\bar{z}\end{array}$ & $\begin{array}{l}\infty \\
\overline{7} \\
z\end{array}$ & $\begin{array}{l}\stackrel{9}{7} \\
\bar{z}\end{array}$ \\
\hline
\end{tabular}




\begin{tabular}{|c|c|c|c|c|c|c|c|c|c|c|}
\hline 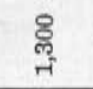 & 가 & 䧺 & $\underset{\sim}{\stackrel{5}{*}}$ & है & 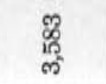 & 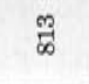 & 品 & $\&$ & 总 & 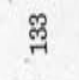 \\
\hline बढ़ڤ & $\infty$ స్త్ర & 1 & 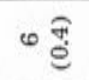 & 1 & 1 & 1 & 1 & 1 & 1 & 1 \\
\hline श्न & Fळ & 宅 & 过商 & శ్సָ & 谒 & 量震 & ढ़ & 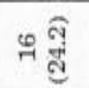 & $8 \overline{\mathrm{E}}$ & 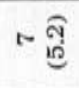 \\
\hline 1 & 1 & 1 & 1 & 1 & 1 & 1 & 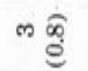 & 1 & 1 & 1 \\
\hline HE్ & 1 & 1 & 1 & 1 & rब & 1 & 1 & 1 & 1 & 1 \\
\hline $\ln \stackrel{\widehat{x}}{\dot{~}}$ & Mब영 & बन & 1 & - & ॠ बठ & 1 & "તิ & 1 & 1 & 1 \\
\hline 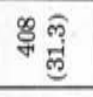 & 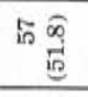 & 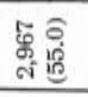 & \&્木 & 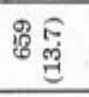 & 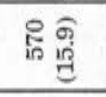 & 8อิ & 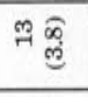 & ${ }^{*} \hat{\underline{e}}$ & 1 & 1 \\
\hline r E⿱ & 1 & r & $r E$ & 1 & 1 & 1 & 1 & 1 & 1 & 1 \\
\hline 1 & 1 & 1 & 1. & 1 & 1 & 1 & 1 & 1 & 1 & 1 \\
\hline 1 & 1 & - & rE్ & 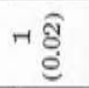 & N & 1 & 1 & 1 & 1 & 1 \\
\hline " สํํ & 1 & r & 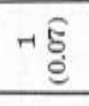 & $\infty \widehat{8}$ & अ & तने & 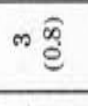 & 1 & न & 1 \\
\hline 1 & 1 & $\nabla \stackrel{E}{E}$ & 1 & $+\widehat{d} \frac{\widehat{g}}{\mathrm{~g}}$ & 1 & 1 & 1 & 1 & 1 & 1 \\
\hline 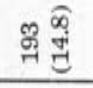 & 계 & 郘 & g g & 雨 & • & 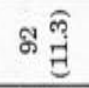 & ने & 噶 & สำ & 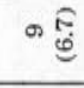 \\
\hline รู ศิ & 1 & 저 ฮู & ๓ ๙ู ชู & 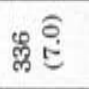 & สำ & ث. & - శత్ & 1 & 1 & 1 \\
\hline 萦滒 & 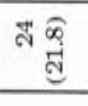 & 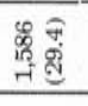 & 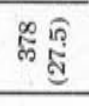 & 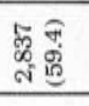 & 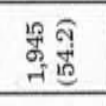 & 苰命 & 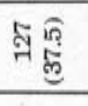 & 踰 & 桑商 & 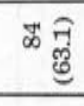 \\
\hline HE్ & 1 & 1 & 1 & 1 & 1 & 1 & 1 & 1 & 1 & 1 \\
\hline ๑્] & 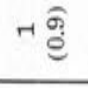 & $E \underset{G}{T}$ & 雨 & 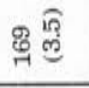 & ஓ్ల & 尺̊. & $\infty$ बึ & 1 & - & 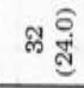 \\
\hline 1 & 1 & 嘫 & 1 & - & 1 & 1 & ๑) & ন & ๙ & HE \\
\hline$F \stackrel{\widehat{\alpha}}{0}$ & 1 & 1 & HE. & 1 & 1 & 1 & 1 & 1 & 1 & 1 \\
\hline ๓ สู & Ha $_{\dot{g}}$ & 1 & N $\hat{g}$ & $\infty \widehat{\underline{\theta}}$ & 1 & 1 & 1 & 1 & 1 & 1 \\
\hline \& & 丞 & 9 & 음 & เี & 몸 & : & 苚 & 吕 & i⿱口 & in \\
\hline 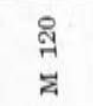 & 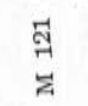 & ส్ & $\begin{array}{l}\mathscr{7} \\
\ddot{z}\end{array}$ & 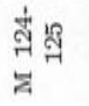 & 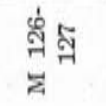 & $\underset{\pi}{\mathbb{z}}$ & 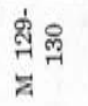 & $\underset{\vec{z}}{\vec{z}}$ & 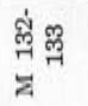 & 蒂品 \\
\hline
\end{tabular}




\begin{tabular}{|c|c|c|c|c|c|c|c|c|c|c|}
\hline & $\vec{\Delta}$ & $\varangle$ & 4 & 4 & m & m & $\varangle$ & 4 & 4 & 4 \\
\hline \multirow{3}{*}{ 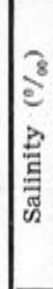 } & . 苟 & 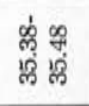 & 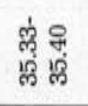 & 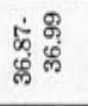 & 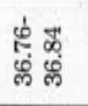 & 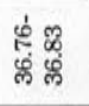 & 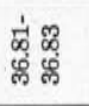 & 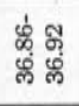 & 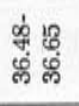 & 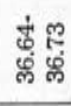 \\
\hline & wo7ł10g & 范 & 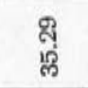 & 衤 & 1 & 1 & 1 & 1 & 1 & 1 \\
\hline & әәвд.ns & 㤐 & 范 & $\begin{array}{l}8 \\
8 \\
8 \\
\end{array}$ & 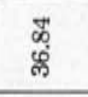 & 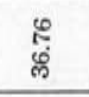 & $\begin{array}{l}\overrightarrow{0} \\
\stackrel{\infty}{\infty} \\
\end{array}$ & ఖ్ & 8 & 胥 \\
\hline \multirow[b]{3}{*}{ F } & 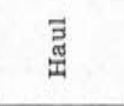 & ซึ่ & 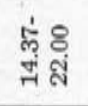 & $\begin{array}{l}\text { జ். } \\
\text { జ్. }\end{array}$ & 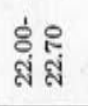 & 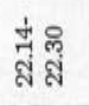 & $\begin{array}{l}\text { मेंक } \\
\text { नें }\end{array}$ & 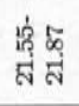 & 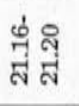 & 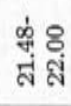 \\
\hline & шо기여 & ఫ్ & 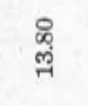 & 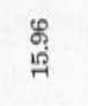 & 1 & 1 & 1 & 1 & 1 & 1 \\
\hline & әәвมر & तें & สి & 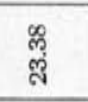 & สั่ & జ్ఞి & ते & 煦 & สิ & $\begin{array}{l}\& \\
\text { สุ }\end{array}$ \\
\hline \multicolumn{2}{|c|}{ 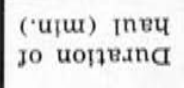 } & 아 & ฉิ & สి & ๙ิ & ๙ి & \& & สิ & N & ㅇ \\
\hline \multicolumn{2}{|c|}{ 茝= } & 量 & 晕 & ํี & 曾 & 罗 & ฝี & 居 & 8 & 兽 \\
\hline \multicolumn{2}{|c|}{ 峈 } & 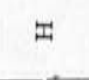 & 1 & 1 & 1 & 1 & 1 & 1 & 1 & 1 \\
\hline \multirow[t]{3}{*}{ छ } & 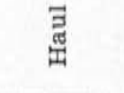 & ล & 诘音 & 㶽 & 唱 & 㶽音 & 跤 & 棓 & 品 & 㶽 \\
\hline & 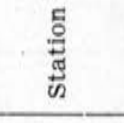 & ช & \& & 㖞 & 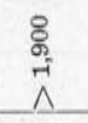 & 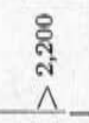 & הి & 高 & $\begin{array}{l}\stackrel{8}{0} \\
\text { N }\end{array}$ & \&్సి \\
\hline & 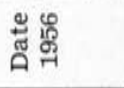 & خ्मे & 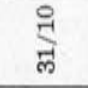 & ङ्मे & స్ت & $\underset{7}{7}$ & $\vec{F}$ & สี & ลี & ลี \\
\hline \multirow[b]{2}{*}{ in } & $\begin{array}{l}B \\
\text { bo } \\
\vdots \\
\vdots\end{array}$ & $\begin{array}{l}\text { 审 } \\
\text { 产 }\end{array}$ & $\begin{array}{l}\text { पे } \\
\text { 今్ } \\
\text { 孚 }\end{array}$ & 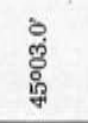 & 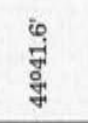 & 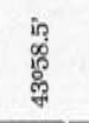 & $\begin{array}{l}\text { कू } \\
\text { \%ू } \\
\text { कू }\end{array}$ & 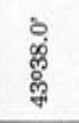 & $\begin{array}{l}\text { 㟧 } \\
\text { हु }\end{array}$ & 㟧 \\
\hline & $\begin{array}{l}\infty \\
\text { 苛 }\end{array}$ & $\begin{array}{l}\text { in } \\
\text { कू } \\
\text { ș }\end{array}$ & 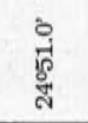 & 客 & สี & 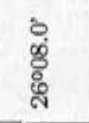 & 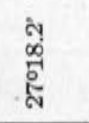 & 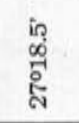 & 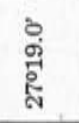 & $\begin{array}{l}\text { ठें } \\
\text { त्रें }\end{array}$ \\
\hline \multicolumn{2}{|c|}{ би иогвาร } & 8 & $\overrightarrow{6}$ & ซึ & 8 & $\ddot{\sigma}$ & $\notin$ & $\varepsilon$ & 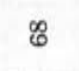 & 8 \\
\hline \multicolumn{2}{|c|}{ 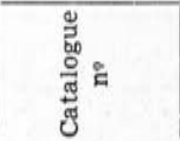 } & 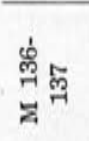 & 参 & $\begin{array}{l}\frac{D}{9} \\
\frac{\pi}{z}\end{array}$ & $\stackrel{P}{\sharp}$ & $\underset{Z}{ \pm}$ & $\underset{z}{\sharp}$ & $\stackrel{9}{ \pm}$ & $\underset{z}{Z}$ & $\frac{\text { 告 }}{z}$ \\
\hline
\end{tabular}




\begin{tabular}{|c|c|c|c|c|c|c|c|c|c|c|c|}
\hline 4 & 4 & 4 & 4 & 4 & 4 & 4 & 4 & 4 & 4 & 4 & 4 \\
\hline 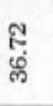 & 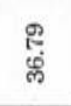 & 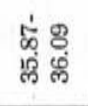 & 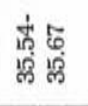 & 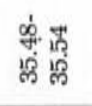 & 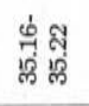 & $\begin{array}{l}\text { 市. } \\
\text { : }\end{array}$ & 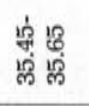 & 品 & $\begin{array}{l}\text { 㤩 } \\
\text { 点 }\end{array}$ & 营落 & 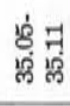 \\
\hline 1 & 哥 & $\begin{array}{l}\overrightarrow{0} \\
\text { 苟 }\end{array}$ & 总 & $\begin{array}{l}980 \\
18 \\
18\end{array}$ & $\begin{array}{l}8.0 \\
\text { 品 }\end{array}$ & $\begin{array}{l}\infty \\
0 \\
0.0 \\
0.8\end{array}$ & 密 & $\begin{array}{l}9 \\
10 \\
18\end{array}$ & 蕰 & 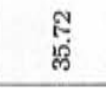 & $\begin{array}{l}8 \\
.80 \\
18 \\
8\end{array}$ \\
\hline స్ & 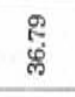 & $\begin{array}{l}\text { 量 } \\
\text { p. }\end{array}$ & 薄 & $\begin{array}{l}\text { 薄 } \\
\text { 夏 }\end{array}$ & $\begin{array}{l}\text { 量 } \\
\text { 晋 }\end{array}$ & 落 & $\begin{array}{l}18 \\
8 \\
8 \\
8\end{array}$ & 黛 & $\begin{array}{l}\text { 营 } \\
\text { 点 }\end{array}$ & $\begin{array}{l}\text { 落 } \\
\end{array}$ & 葛 \\
\hline $\begin{array}{l}8 \\
\text { से }\end{array}$ & 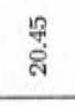 & 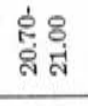 & केंสี & 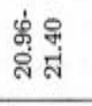 & 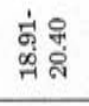 & 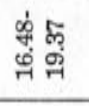 & 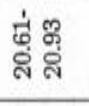 & $\begin{array}{l}\text { ک్ } \\
\text { ه్ }\end{array}$ & $\begin{array}{l}\text { : } \\
\text {. }\end{array}$ & 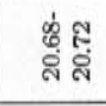 & 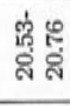 \\
\hline 1 & 曽 & 总 & 駡 & 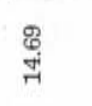 & 薄 & $\begin{array}{l}\text { 莒 } \\
\text { 虽 }\end{array}$ & 苞 & $\begin{array}{l}\text { 总 } \\
\text { 量 }\end{array}$ & 劳 & $\begin{array}{l}\text { 量 } \\
\text { 尊 }\end{array}$ & 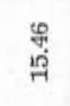 \\
\hline ڤె & 㝵 & F్ & สิ & 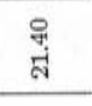 & 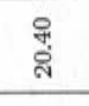 & 第 & ढ़ & ণू & 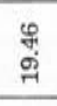 & 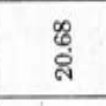 & ְّ̊ \\
\hline స్ & ๙ & สิ & ㅇ & ๑ి & สิ & ลิ & ลิ & สิ & สิ & ㅇ & ลั \\
\hline 桑 & 룡 & : & $\stackrel{\square}{7}$ & 罵 & 尊 & ఫ्ने & 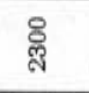 & 啹 & 웡 & 量 & 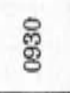 \\
\hline I & म' & 1 & 1 & 1 & 1 & 1 & 1 & I & I & 1 & 1 \\
\hline 0 & 0 & 㶽 & 品言 & 品言 & 诘音 & 路音 & 蟙 & 0 & 0 & 品离 & 品音 \\
\hline $\begin{array}{l}\stackrel{8}{8} \\
-1 \\
\Lambda\end{array}$ & 5 & ตั & 照 & i & 㖞 & ฮี & 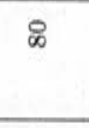 & 8 & $\stackrel{8}{7}$ & $\infty$ & $\underset{\sim}{\infty}$ \\
\hline స్ & $\underset{\infty}{*}$ & $\cdot \vec{\infty}$ & $\underset{\infty}{7}$ & స్ & 곰 & 茼 & 营 & స్ & స్ & సี & స్ \\
\hline ปี & $\begin{array}{l}\text { oे } \\
\text { क्ष } \\
\text { के }\end{array}$ & 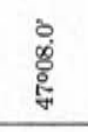 & 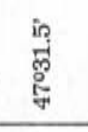 & $\begin{array}{l}\text { ip } \\
\text { 总 } \\
\text { 点 }\end{array}$ & 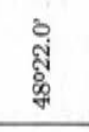 & 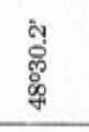 & $\begin{array}{l}\text { 心 } \\
\text { 洛 } \\
\text { s. }\end{array}$ & 产 & สั่ & $\begin{array}{l}\dot{\circ} \\
\dot{\delta} \\
\dot{5}\end{array}$ & 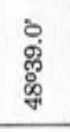 \\
\hline 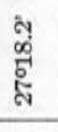 & $\begin{array}{l}\text { ठें } \\
\text { ठ̀े }\end{array}$ & $\begin{array}{l}\text { के } \\
\text { क्. }\end{array}$ & $\begin{array}{l}\text { के } \\
\text { 心ू. }\end{array}$ & 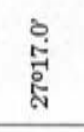 & 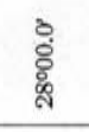 & 岕 & $\begin{array}{l}\text { 旅 } \\
\text { 总 }\end{array}$ & 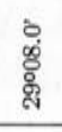 & 密 & 商 & 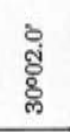 \\
\hline i & $F$ & ఇ & 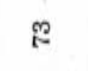 & F & \& & 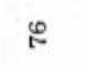 & $F$ & $\mathscr{D}$ & \% & ๑ & $\vec{\Phi}$ \\
\hline i & $\begin{array}{l}\text { 亲 } \\
\text { 至 }\end{array}$ & 悉 & $\begin{array}{l}\text { I } \\
\vec{z}\end{array}$ & 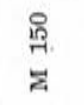 & 窎路 & $\frac{\stackrel{g}{g}}{\ddot{z}}$ & $\begin{array}{l}\text { 莦 } \\
\text { 至 }\end{array}$ & $\begin{array}{l}\frac{B}{8} \\
\frac{a}{z}\end{array}$ & $\frac{\stackrel{h}{H}}{\frac{a}{z}}$ & 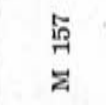 & $\begin{array}{l}\stackrel{\infty}{h} \\
\stackrel{2}{z}\end{array}$ \\
\hline
\end{tabular}




\begin{tabular}{|c|c|c|c|c|c|c|c|c|c|c|c|}
\hline & $\begin{array}{l}\text { पूँ } \\
\check{z}\end{array}$ & 4 & $<$ & 4 & 4 & 4 & 4 & 4 & 4 & 4 & 4 \\
\hline \multirow{3}{*}{ 施 } & 㯊 & 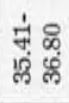 & 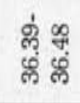 & 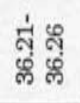 & 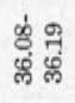 & 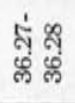 & 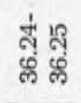 & 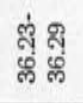 & 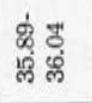 & 咚 & 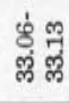 \\
\hline & uonog & 1 & 1 & 1 & 1 & 1 & 1 & 1 & 1 & 1 & ำ \\
\hline & อวвน.นns & ซึ่ & 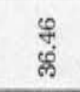 & సี & 站 & స్ & त्் & สุ & 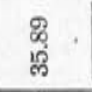 & ำ & 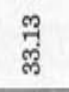 \\
\hline \multirow{3}{*}{ 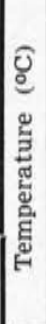 } & 楚 & 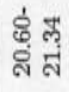 & 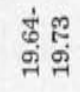 & $\underset{\sim}{\infty}$ & 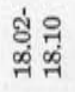 & 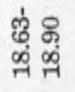 & 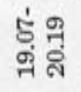 & $\stackrel{\infty}{\rightarrow} \underset{\sim}{\infty} \underset{\sim}{\infty}$ & 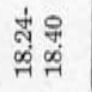 & $\begin{array}{l}\text { హ్ } \\
\text { क्ने }\end{array}$ & 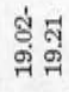 \\
\hline & uopyog & 1 & 1 & 1 & 1 & 1 & 1 & 1 & 1 & I & $\begin{array}{l}\mathscr{H} \\
\text { @ }\end{array}$ \\
\hline & อวษน.นns & స్ & $\begin{array}{l}\text { ஜே} \\
\text { ఏ }\end{array}$ & 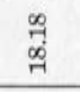 & $\stackrel{ }{\stackrel{7}{7}}$ & $\begin{array}{l}\stackrel{\$}{\circ} \\
\text { న }\end{array}$ & สิ่ & 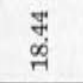 & 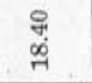 & $\begin{array}{l}\text { హ゙ } \\
\text { g }\end{array}$ & సี่ \\
\hline \multicolumn{2}{|c|}{$\begin{array}{l}\text { ('ujux) Inв4 } \\
\text { jo uoןe.snd }\end{array}$} & สิ & สิ & ิㅗ & สิ & ลิ & ิํ & ศิ & สิ & ลิ & สิ \\
\hline \multicolumn{2}{|c|}{ 岕 } & สิ & $\frac{10}{5}$ & 营 & 융 & $\frac{10}{8}$ & $\underset{1}{18}$ & ผิ & ํํㅇ & 양 & $\begin{array}{l}\infty \\
8 \\
8\end{array}$ \\
\hline \multicolumn{2}{|r|}{ 司 } & 1 & 1 & 1 & I & 1 & 1 & 1 & 1 & 1 & 1 \\
\hline \multirow{2}{*}{ 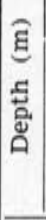 } & 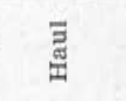 & $\odot$ है & ํํ है & 을 & in & 䟲 & เि हू & 골 & ล & 决 & 距 \\
\hline & 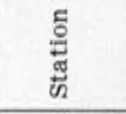 & $\frac{10}{6}$ & $\begin{array}{l}8 \\
0 \\
-1\end{array}$ & $\begin{array}{l}\text { \& } \\
\text { के } \\
\wedge\end{array}$ & $\begin{array}{l}8 \\
\infty \\
\text { లో }\end{array}$ & 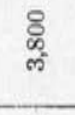 & \begin{tabular}{l}
8 \\
\hdashline \\
4 \\
$\wedge$
\end{tabular} & 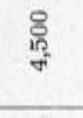 & $\begin{array}{l}8 \\
\text { î } \\
\wedge \\
\wedge\end{array}$ & $\stackrel{8}{-}$ & 㸃 \\
\hline \multicolumn{2}{|c|}{ 志䓫 } & $\overbrace{6}^{-1}$ & $\vec{c}^{-1}$ & $\overbrace{6}^{-1}$ & E & $\sum_{5}^{-1}$ & $\stackrel{-1}{5}$ & E & $\vec{\infty}$ & สุ & సี \\
\hline \multirow{2}{*}{$\begin{array}{l}5 \\
0 \\
\Xi \\
\Xi \\
\text { n } \\
0 \\
n_{1}\end{array}$} & $\begin{array}{l}B \\
00 \\
5 \\
5\end{array}$ & $\begin{array}{l}\text { के } \\
\text { क्ष } \\
\text { कू }\end{array}$ & 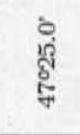 & 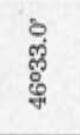 & $\begin{array}{l}\text { 우 } \\
\text { in } \\
\text { 章 }\end{array}$ & 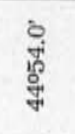 & $\begin{array}{l}\text { 우 } \\
\text { 해 } \\
\text { दु }\end{array}$ & 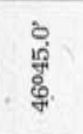 & 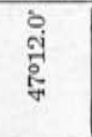 & 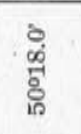 & $\begin{array}{l}\text { हैं } \\
\text { है } \\
\text { मै }\end{array}$ \\
\hline & क & $\begin{array}{l}\text { के } \\
\text { क्षे }\end{array}$ & 官 & 官 & 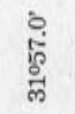 & के & $\begin{array}{l}\text { के } \\
\text { के } \\
\text { ஜू }\end{array}$ & के & 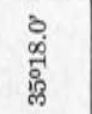 & 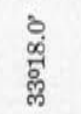 & $\begin{array}{l}\text { के } \\
\text { कूँ } \\
\text { क्षे }\end{array}$ \\
\hline \multicolumn{2}{|c|}{ ou uo!ams } & ศั & $\not$ & 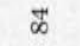 & 18 & $\ddot{\infty}$ & 5 & \& & ஜి & హ゙ & \& \\
\hline \multicolumn{2}{|r|}{ 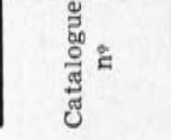 } & $\begin{array}{l}\stackrel{9}{a} \\
\stackrel{2}{2}\end{array}$ & $\begin{array}{l}\stackrel{8}{0} \\
\stackrel{1}{2}\end{array}$ & 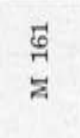 & $\begin{array}{l}\text { @ै } \\
\text { ¿ }\end{array}$ & $\begin{array}{l}\text { ஜ } \\
\stackrel{-}{二}\end{array}$ & 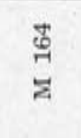 & $\begin{array}{l}\stackrel{Ð}{二} \\
\frac{\pi}{2}\end{array}$ & $\begin{array}{l}\stackrel{5}{6} \\
\stackrel{2}{2}\end{array}$ & $\begin{array}{l}E \\
\vec{H} \\
\overrightarrow{2}\end{array}$ & 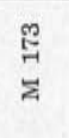 \\
\hline
\end{tabular}




\begin{tabular}{|c|c|c|c|c|c|c|c|c|c|c|}
\hline 4 & 4 & 4 & 4 & 4 & 4 & 4 & 4 & 4 & 4 & \\
\hline 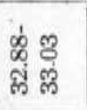 & 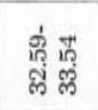 & 蜜品 & 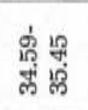 & 点 & 蜜品 & 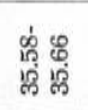 & 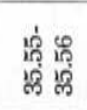 & 霝落 & 宷: & \\
\hline 多 & $\vec{F}$ & 营 & 8 & 量 & 曾 & 菬 & 量 & 落 & 密 & \\
\hline 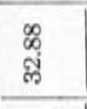 & 总 & $\stackrel{\square}{\%}$ & 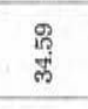 & $\begin{array}{l}\text { 管 } \\
\end{array}$ & 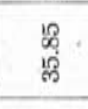 & 8 & 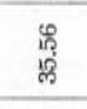 & 落 & 要 & \\
\hline 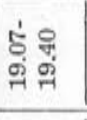 & 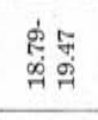 & สู่ & 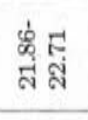 & 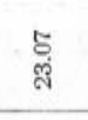 & 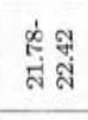 & $\begin{array}{l}\text { पेंळ } \\
\text { जे }\end{array}$ & क्षे & غ્ં & 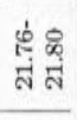 & \\
\hline 总 & 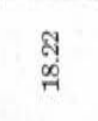 & 迎 & 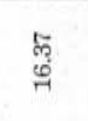 & : & $\underset{్}{7}$ & 范 & $\begin{array}{l}\text { 脶 } \\
\text { 昜 }\end{array}$ & 8 & 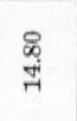 & \\
\hline 曾 & $\underset{0}{0}$ & สํ. & สี & 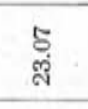 & สี & 奈 & $\frac{8}{\pi}$ & \% & 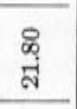 & \\
\hline 우 & \% & \% & ๙ & : & \% & \& & ๙ & ๙ి & ส & \\
\hline 兽 & ีㅠ & 道 & $\stackrel{7}{7}$ & 哭 & ๕్టి & 照 & 照 & . & 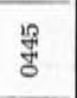 & \\
\hline 1 & 1 & 1 & 1 & \# & 1 & 1 & 1 & 1 & 1 & \\
\hline 赔 & 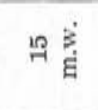 & 䟲 & 喑 & 。 & 嚾 & 影 & 踣 & 的音 & 虾 & \\
\hline $\mathscr{8}$ & 9 & 8 & 品 & 8 & R & P & 8 & i⿱ & 吕 & 澷 \\
\hline नี & సี & 营 & $\underset{7}{7}$ & 陑 & 掌 & 窝 & 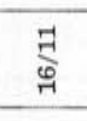 & $\underset{0}{7}$ & 莺 & \\
\hline 商 & 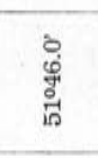 & 嵩 & 兽 & 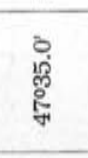 & 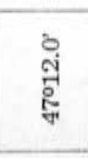 & 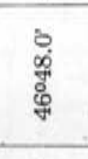 & हुं & 商 & 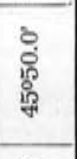 & \\
\hline 它 & 㻤 & 悹 & 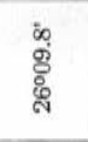 & 悹 & $\begin{array}{l}\text { 总 } \\
\text { 恖 }\end{array}$ & 总 & 吂 & $\begin{array}{l}\text { 总 } \\
\text { Wh }\end{array}$ & 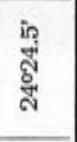 & 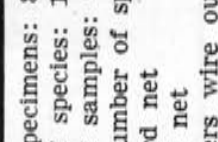 \\
\hline ริ & $\infty$ & 总 & $\stackrel{\square}{-}$ & 点 & $\stackrel{\infty}{\circ}$ & g & 우 & 专 & \# & 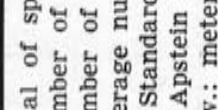 \\
\hline$\underset{ت}{\vec{H}}$ & 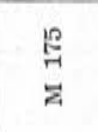 & $\underset{Z}{E}$ & 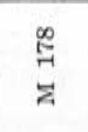 & 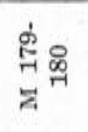 & $\underset{\vec{z}}{\vec{\Phi}}$ & $\underset{\nexists}{\mathbb{Z}}$ & $\underset{\mathbb{Z}}{\mathbb{Z}}$ & $\underset{\vec{z}}{\overrightarrow{\mathrm{D}}}$ & 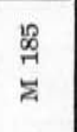 & \\
\hline
\end{tabular}




\begin{tabular}{|c|c|c|c|c|c|c|c|c|c|c|}
\hline & 噧 & $\Xi$ & N & \&్ & in & $n$ & 오ํ & 5 & है & ๕్ \\
\hline & 惖 & in & 1 & 获 & "- क्षे & $\begin{array}{l}-1 \text { कू } \\
\text { हुర }\end{array}$ & §ิ & ఇ & लै & भู नิ \\
\hline & 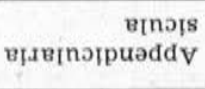 & 1 & 1 & 1 & 1 & 1 & 1 & 1 & 1 & 1 \\
\hline & 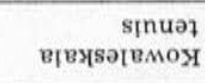 & 1 & 1 & 1 & 1 & 1 & 1 & 1 & 1 & 1 \\
\hline \multirow{6}{*}{ 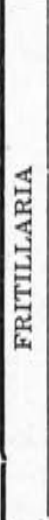 } & 'ds & 1 & 1 & 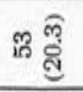 & 1 & 1 & ๓ & कन & ז & ㅋำ \\
\hline & epґnIləd & 1 & 1 & 유 & 1 & 1 & '- & Hô & $\stackrel{\circ}{0}$ & 굴 \\
\hline & әเบวยริวน & 1 & 1 & 1 & 1 & 1 & 1 & 1 & 1 & 1 \\
\hline & 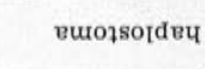 & 1 & 1 & - बैं & 1 & 1 & ") & 1 & कन्त & 1 \\
\hline & вогшио & 1. & 1 & m न & 1 & 1 & สุ & H) & in $\stackrel{\infty}{d}$ & क न \\
\hline & sนाвว.0q & 1 & 1 & N है & 1 & 1 & 1 & 1 & m & 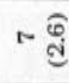 \\
\hline & $\begin{array}{r}\text { unuseu } \\
\text { вưsoรอาs }\end{array}$ & 1 & 1 & 1 & 1 & 1 & 1 & 1 & 1 & 1 \\
\hline \multirow{11}{*}{ 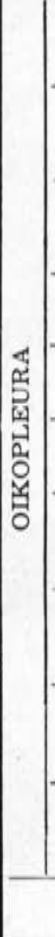 } & 'ds & ลี & 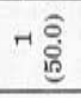 & ळ & N & N & 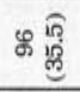 & क्ल हैं & 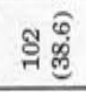 & 흉 \\
\hline & suəosəzn $x$ & 1 & 1 & N & 1 & 1 & m & I & I & ค คิ \\
\hline & врпвวรีนоั & 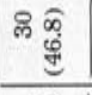 & r) & ํํㅇํํ & $\begin{array}{r}-10 \\
\text { 옹 }\end{array}$ & 1 & 오ำ & 气第 & ลำ & 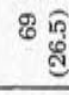 \\
\hline & втрәшхәэ) & त्र & 1 & 1 & 1 & 1 & 1 & 1 & 1 & 1 \\
\hline & sәртопюв.я & 1 & 1 & 1 & 1 & 1 & 1 & 1 & 1 & 1 \\
\hline & รџюв. & 1 & 1 & 1 & 1 & 1 & न ભ & I & 1 & 1 \\
\hline & șu.xoJsn & 1 & 1. & " बै & ") & 1 & ") & rộ & NE & ๑ึู \\
\hline & вวюгор & 1 & 1 & 1 & 1 & 1 & 1 & 1 & 1 & 1 \\
\hline & вว.хววоч Һоว & 1 & 1 & 1 & 1 & 1 & - ભ̣ & ㄱำ สู & 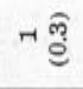 & 1 \\
\hline & suвगรवाв & 1 & 1 & 1 & 1 & 1 & 1 & 1 & 1 & 1 \\
\hline & ¿U uonkา & 8 & है & ชิ & 8 & $\Xi$ & 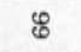 & 6 & 80 & 8 \\
\hline \multicolumn{2}{|r|}{ ๑и әпรоโорв } & 廄点 & $\begin{array}{l}\stackrel{\infty}{\pi} \\
\ddot{z}\end{array}$ & 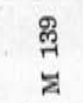 & 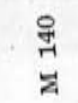 & $\underset{n}{\vec{z}}$ & 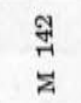 & 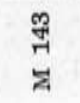 & $\underset{7}{\sharp}$ & $\frac{18}{2}$ \\
\hline
\end{tabular}




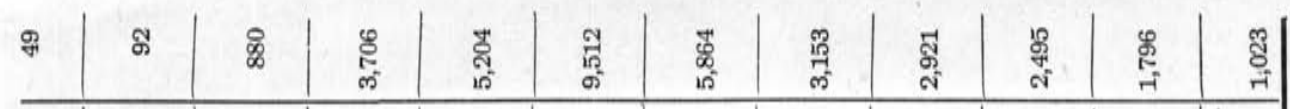

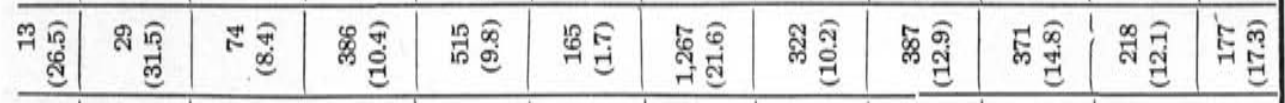

\begin{tabular}{|c|c|c|c|c|c|c|c|c|c|c|}
\hline 1 & 1 & 1 & 1 & 1 & 1 & 1 & 1 & 1 & 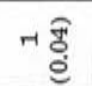 & 1 \\
\hline 1 & 1 & 1 & 1 & • 클 & in & 1 & 1 & ๑ ิู & * नी & 1 \\
\hline
\end{tabular}

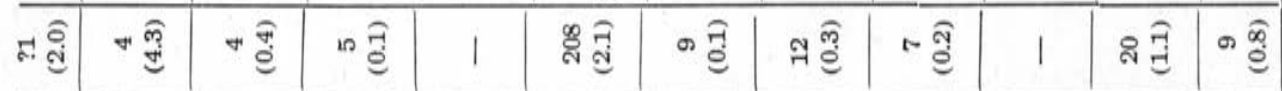

\begin{tabular}{|c|c|c|c|c|c|c|c|c|c|c|c|}
\hline r & rô & 1 & $\stackrel{9}{\rightarrow}$ & 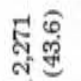 & 串 & 危点 & 品点 & 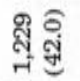 & 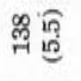 & શิ क़ & 50 \\
\hline
\end{tabular}

\begin{tabular}{|c|c|c|c|c|c|c|c|c|c|c|c|}
\hline 1 & 1 & 1 & 1 & 1 & N & 1 & 1 & N $\begin{array}{l}\hat{8} \\
\text { हैं }\end{array}$ & 1 & न & 1 \\
\hline 1 & ๙ तु & 구 ભิ & הี & สูก สู & $\begin{array}{l}\& 6 \\
\overline{0} \\
70 \\
\text { in }\end{array}$ & 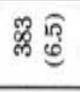 & $\stackrel{\star}{~}$ & సึ: & 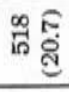 & $\notin \stackrel{6}{0}$ & 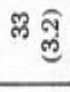 \\
\hline 1 & ๙ సิ & 1 & - శ్ & m & $+\widehat{8}$ & 1 & I & 1 & 1 & 1 & I \\
\hline$\pi \stackrel{\widehat{\leftrightarrow}}{\mathrm{i}}$ & 1 & - & ๙ ศิ & ־ & ำ ભુ & 1 & N & สิ 仓્ర & r ฮู & ๙ नิํㄹ & ๙ \\
\hline 1 & 1 & 1 & 1 & 1 & 1 & 1 & N & 1 & 1. & 1 & N సี \\
\hline ला है & 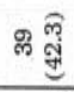 & 곤 & ถึ. ํํํ & ซึ: & 号它 & 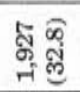 & ต้ สุ & జ్టె & ণู & ్ㅗㅇ త్రి & స్ \\
\hline 1 & 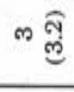 & $+\hat{~}$ & ๑) & N & N ิู & N & \& & m हैं & N & 굑 & F) \\
\hline 1 & 구 & 橗 施 & 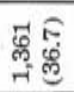 & है & 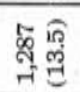 & 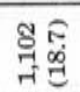 & 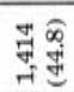 & 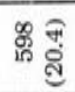 & 莳 & ஜू क्ष & 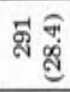 \\
\hline
\end{tabular}

\begin{tabular}{|c|c|c|c|c|c|c|c|c|c|c|c|}
\hline N $\widehat{\stackrel{+}{+}}$ & Hô & क न & 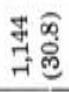 & 哭 & 궅 & 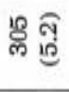 & E્ & ัํำ & 㴦 突 & 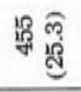 & 윽 \\
\hline 1 & 1 & 1 & 1 & 1 & ஜूँ & N & 1 & Hô & N & 1 & \\
\hline
\end{tabular}

\begin{tabular}{|c|c|c|c|c|c|c|c|c|c|c|c|}
\hline I & 1 & 1 & 1 & 1 & 1 & 1 & N & 1 & 1 & 1 & 1 \\
\hline 오 & $F$ & ก & ฉ & $\pi$ & in & $\stackrel{R}{*}$ & $E$ & $\stackrel{\infty}{\infty}$ & R & 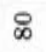 & $\vec{\infty}$ \\
\hline$\underset{r}{\mathscr{H}}$ & 学 & $\underset{\sim}{\stackrel{\infty}{\sim}}$ & $\underset{7}{\stackrel{8}{7}}$ & 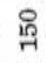 & 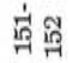 & 跑 & 点 & 量 & 哭 & 点 & 桌 \\
\hline$\Sigma$ & 추 & $\Sigma$ & $\Sigma$ & 년 & $\bar{z}$ & $\Sigma$ & $\Sigma$ & 齐 & 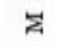 & 只 & $z$ \\
\hline
\end{tabular}




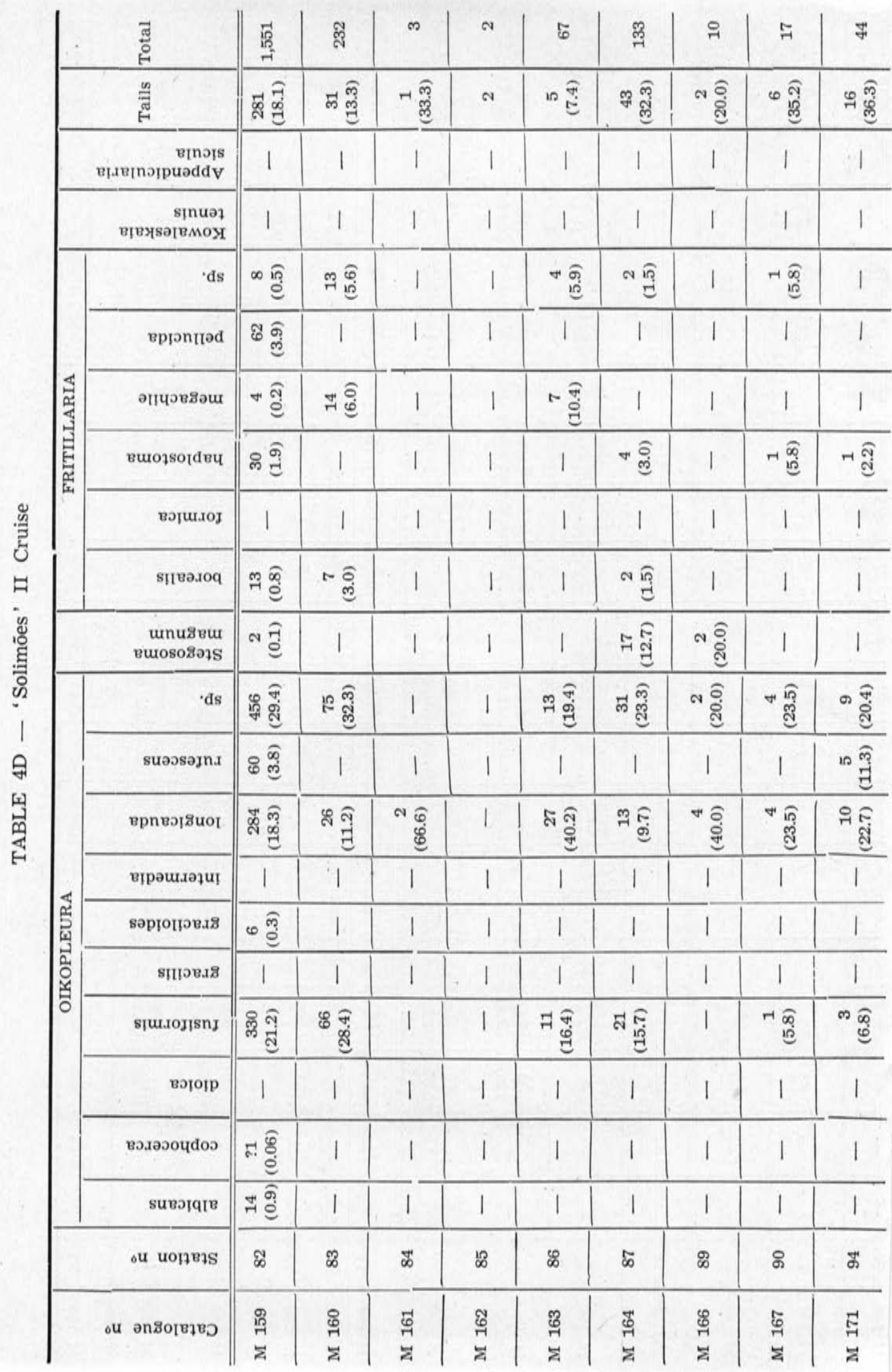




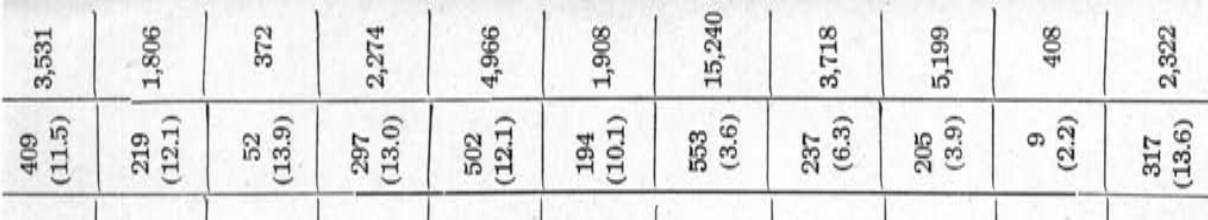

\begin{tabular}{|c|c|c|c|c|c|c|c|c|c|c|}
\hline 1 & 1 & 1 & 1 & 1 & サ สู & 1 & 1 & 1 & 1 & 1 \\
\hline 1 & 1 & 1 & 1 & ๗゙ & ๒ ิู & 1 & 1 & 1 & 1 & 1 \\
\hline 1 & 1 & 1 & 1 & 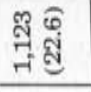 & 감 & ๙ึ สู & N & ำ ริ & 1 & 1 \\
\hline 1 & 1 & 1 & 1 & 1 & 1 & 1 & 1 & 1 & 1 & 1 \\
\hline 1 & 1 & 1 & 1 & कन न्है & ㄱํ욜 & เ 공 & ๓ & 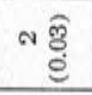 & 1 & m \\
\hline 1 & 1 & 1 & 1 & m & 1 & 1 & 1 & 1 & 1 & 1 \\
\hline 1 & 1 & 1 & 1 & •) & " ลู & 1 & 1 & 1 & 1 & 1 \\
\hline 1 & 1 & 1 & 1 & 1 & 1 & 1 & 1 & 1 & 1 & 1 \\
\hline 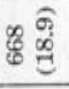 & ल & స్త్ర & 吅 ్ㅗㅁ & 跑 & 串 & 롱 & 苛 & 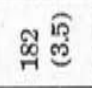 & in & 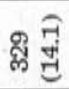 \\
\hline 월 & ฉి స్ & 10 & 1 & 1 & 1 & $H$ & 1 & 1 & 1 & 1 \\
\hline E) & 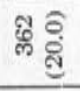 & 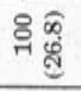 & 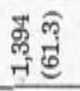 & 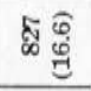 & न्ञ & 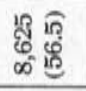 & 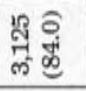 & $\begin{array}{l}\text { 点 } \\
\text { 号 }\end{array}$ & 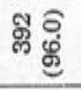 & 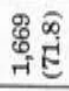 \\
\hline 1 & $!$ & 1 & 1 & 1 & 1 & 1 & 1 & 1 & N Æ़่ & 1 \\
\hline
\end{tabular}

\begin{tabular}{|c|c|c|c|c|c|c|c|c|c|c|}
\hline 1 & 1 & 1 & 1 & 1 & 1 & 1 & 1 & 1 & 1 & 1 \\
\hline 1 & 1 & 1 & 1 & 1 & 1 & 1 & 1 & 1 & 1 & 1 \\
\hline 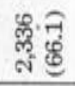 & 8 点 & กิ & 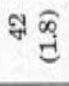 & 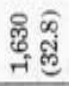 & ஜֶ & ฟึิ สู่ & $\underset{F}{E}$ & न & 1 & $*$ 을 \\
\hline$+\hat{\varepsilon}$ & लै & สู & $F \stackrel{\text { }}{\mathrm{C}}$ & 1 & 1 & 1 & 1 & 1 & 1 & 1 \\
\hline 1 & 1 & 1 & 1 & 1 & 1 & 1 & 1 & 1 & 1 & 1 \\
\hline 1 & 1 & 1 & 1 & 1 & 1 & 1 & 1 & 1 & 1 & 1 \\
\hline $\mathscr{H}$ & 5 & $\mathscr{\%}$ & Bg & $\stackrel{1}{\sharp}$ & 5 & $\stackrel{\circ}{\circ}$ & \& & 윽 & $\exists$ & Эี \\
\hline ஜ્ఝ & 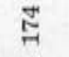 & $\stackrel{18}{7}$ & E & $\underset{\mathrm{R}}{\mathrm{f}}$ & 它。 & ్ㅠㄱ & ్్ㅁ & $\underset{\mathscr{Z}}{\mathscr{H}}$ & 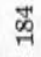 & $\underset{\sim}{\stackrel{10}{-1}}$ \\
\hline 云 & z & $\Sigma$ & $\bar{z}$ & $\Sigma$ & $\Sigma^{\top}$ & $\Sigma$ & $\Sigma$ & $z$ & $z$ & 국 \\
\hline
\end{tabular}

